\title{
Piscicultura e meio ambiente, estudos e perspectivas na Amazônia
}
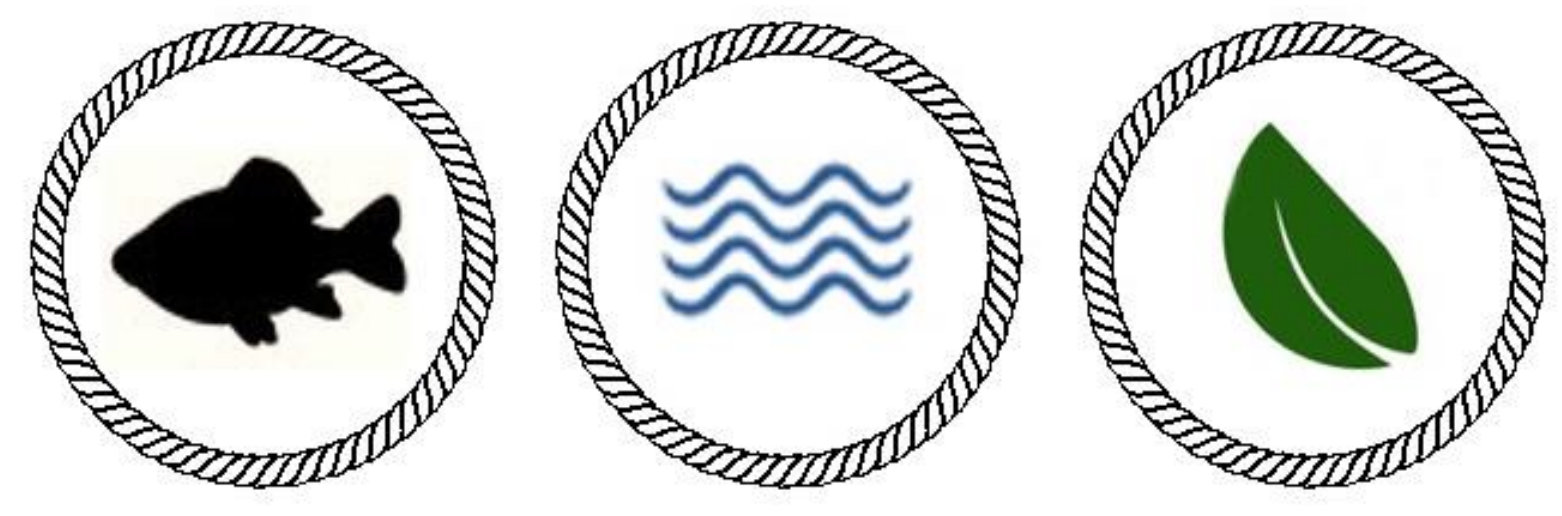


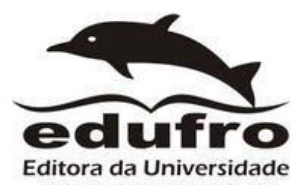

Editora da Universidad Federal de Rondônia

Av. Presidente Dutra, 2965 - Centro Porto Velho - RO - CEP: 76801-974

Fone: (69) 2182-2175

www.edufro.unir.br

edufro@unir.br 


\section{JUCILENE CAVALI \\ YURI VINÍCIUS DE ANDRADE LOPES}

(Orgs.)

\section{Piscicultura e meio ambiente, estudos e perspectivas na Amazônia}


P676

Piscicultura e meio ambiente, estudos e perspectivas na Amazônia / Organizadores Jucilene Cavali, Yuri Vinícius de Andrade Lopes. Edufro, Porto Velho, Rondônia, 2017.

157 p. :il.

ISBN: 978-85-7764-091-1

1. Piscicultura 2. Manejo 3. Recursos hídricos 4. Sustentabilidade I. Cavali, Jucilene, Lopes II. Yuri Vinícius de Andrade. III. Título.

CDU: $369.3(811)$

Bibliotecária Responsável: Ozelina Saldanha CRB11/486

Preparo de originais: Autor(es)

Revisão Gramatical: Autor(es)

Revisão de Normas Técnicas: Autor(es)
Diagramação capa: Autores

Composiçõa: EDUFRO

Editor: Jairo André Schlindwein

Fundação Universidade Federal de Rondônia

\author{
Ari Miguel Teixeira Ott \\ Reitor \\ Marcelo Vergotti \\ Vice-Reitor \\ Adilson Siqueira de Andrade \\ Chefe de Gabinete \\ Charles Dam Souza Silva \\ Pró-Reitor de Administração
}

Otacílio Moreira de Carvalho Costa Pró-Reitor de Planejamento

Jorge Luiz Coimbra de Oliveira Pró-Reitora de Graduação

Leonardo de Azevedo Calderon

Pró-Reitora de Pós-Graduação e Pesquisa

Marcele Regina Nogueira Pereira

Pró-Reitor de Cultura, Extensão e Assuntos Estudantis

\section{Conselho Editorial da EDUFRO:}

Jairo André Schlindwein (Prof. UNIR), José Lucas Pedreira Bueno (Prof. UNIR), Emanuel Fernando Maia de Souza (Prof. UNIR), Rubiani de Cássia Pagotto (Profa. UNIR), Osmar Siena (Prof. UNIR), Júlio César Barreto Rocha (Prof. UNIR), Marli Lucia Tonatto Zibetti (Profa. UNIR), Sirlaine Galhardo Gomes Costa (Bibliotecaria. UNIR), Cléberson de Freitas Fernandes (EMBRAPA), Dante Ribeiro da Fonseca (ACLER).

Depósito legal na Biblioteca Nacional conforme Lei no 10.994, 14 de dezembro de 2004.

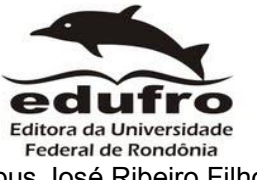

Campus José Ribeiro Filho

BR 364, Km 9,5 - Porto Velho - RO

CEP: $78900-000$

www.edufro.unir.br

edufro@unir.br 


\section{SUMÁRIO}

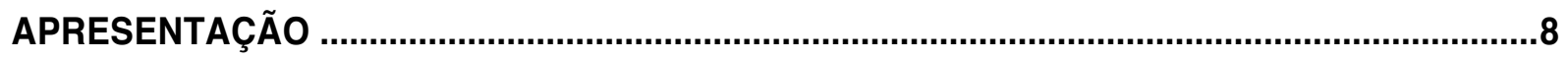

A importância da floresta na organização das assembleias de peixes de igarapés da bacia

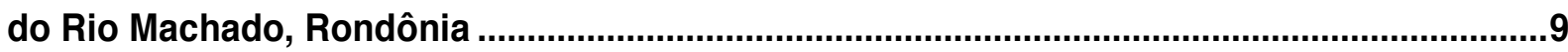

Fundamentos em manejo alimentar de pirarucu .............................................................21

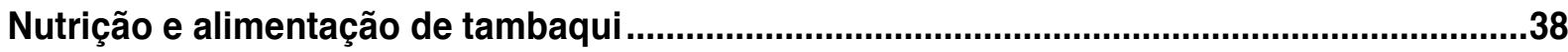

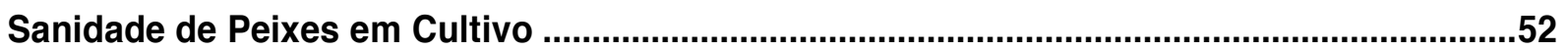

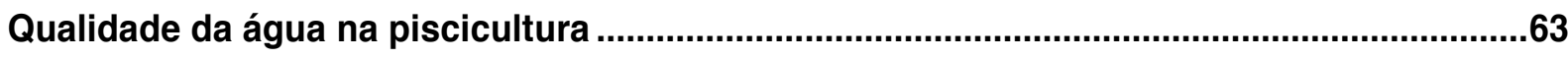

Desenvolvimento da carcinicultura no Brasil ...........................................................................

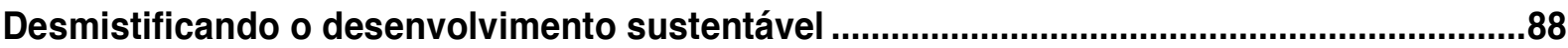

Cenário das Indústrias de Beneficiamento do Pescado em Rondônia ...................................99

Regularização de projetos de piscicultura no estado de Rondônia ......................................108

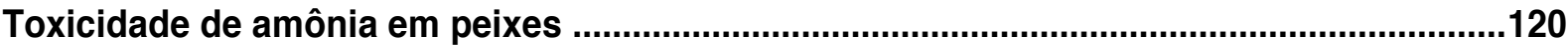

Boas práticas de manejo para sanidade em pisciculturas ..............................................140 


\section{APRESENTAÇÃO}

O Estado de Rondônia é o maior produtor de peixes nativos do Brasil, com grande potencial de expansão em tecnificação dos sistemas de cultivo e abertura de novos mercados consumidores de Pescado. Tem como carro chefe espécies de peixes tropicais como Tambaqui (Colossoma macropomum) e Pirarucu (Arapaima gigas), adaptados ás condições climáticas da Região Norte elevadas taxas de crescimento em condições de cativeiro.

A consolidação deste livro representa a conclusão de um desafio aceito pelos docentes engajados no curso de engenharia de pesca e de zootecnia do estado de Rondônia, que trabalharam intensamente para que fosse possível o registro de resultados de pesquisas realizadas nas diversas áreas da aquicultura como os aspectos da carcinocultura e a situação ecologia sobre reservas biológicas no estado de Rondônia. Contudo, diante da posição ocupada pelo Estado no cenário produtivo nacional, maior foco foi dado ás pesquisas em piscicultura considerando diagnóstico de suas condições de cultivo, manejo sanitário e alimentar e alternativas para o aumento da produtividade através da implementação de novas tecnologias que reduzam os impactos ambientais e propulsionem um pescado de melhor qualidade para as agroindústrias.

Organizadores

Jucilene Cavali

Engenheira Agrônoma, Dra em Zootecnia. Departamento de Zootecnia da UNIR jcavali@unir.br

Yuri Vinícius de Andrade Lopes

Engenheiro de Pesca, Mestre em Ciência Animal. Departamento de Engenharia de Pesca da UNIR. yuri.andrade@unir.br 


\section{A importância da floresta na organização das assembleias de peixes de igarapés da bacia do Rio Machado, Rondônia}

Igor David da Costa ${ }^{1}$, Rosana Mazzoni ${ }^{2}$

\section{Introdução}

A região Amazônica possui a maior bacia hidrográfica do mundo, sendo formada pelo rio Amazonas e um incontável número de outros rios e pequenos igarapés, distribuídos por uma área de aproximadamente 300.000 Km² (JUNK, 1983; SANTOS, FERREIRA, 1999). Rios e riachos são componentes importantes das paisagens continentais, representam cerca de um centésimo da superfície terrestre, porém apenas um décimo de milionésimo da quantidade de água presente no globo (HYNES, 1972).

Segundo Miserendino et al (2011), é esperado que fatores relacionados à paisagem influenciem a fauna de vertebrados aquáticos. Para peixes, muitos estudos têm apontado os efeitos das alterações na cobertura do solo e a subsequente redução da qualidade ambiental sobre a estrutura das assembleias, que apresentam mudanças na composição de espécies e nos indicadores de diversidade, como riqueza, uniformidade e dominância (TERESA, CASATTI, 2012).

O processo de desflorestamento se estabelece por inúmeras razões, sendo a pecuária um fator central, dado a área ocupada e expansão contínua (FEARNSIDE, 2005). A ação antrópica, aliada às políticas de desenvolvimento, mineração, obras de infraestrutura e exploração irregular de madeira, são os principais fatores determinantes para o avanço do desflorestamento na Amazônia (FERREIRA et al, 2005).

No Brasil, uma das principais estratégias para conter o desflorestamento na Amazônia tem sido a criação de áreas protegidas. O efeito inibitório do desmatamento ocasionado pela presença destas áreas em regiões submetidas à

${ }^{1}$ Biólogo, Dr em Ecologia e Evolução. Departamento de Engenharia de Pesca da Universidade Federal de Rondônia. igordavid@unir.br

${ }^{2}$ Bióloga, Dra em Ecologia e Recursos Naturais. Departamento de Ecologia da Universidade do Estado do Rio de Janeiro. 
forte pressão antrópica representou uma das principais motivações para a recente expansão do programa de unidades de conservação (UCs) na Amazônia (SOARESFILHO et al, 2010). Até dezembro de 2010 uma área de $2.197 .485 \mathrm{~km}^{2}$ foi designada para proteção dos recursos naturais na Amazônia Legal, sob a forma de unidades de conservação (UCs) implementadas sob diferentes regimes de uso e grau de intervenção (proteção integral ou uso sustentável) nas diferentes esferas governamentais (VERÍSSIMO et al, 2011).

Figura 1 - Proporção do desmatamento dentro e fora das áreas protegidas na Amazônia legal e nos Estados de Mato Grosso, Pará e Rondônia

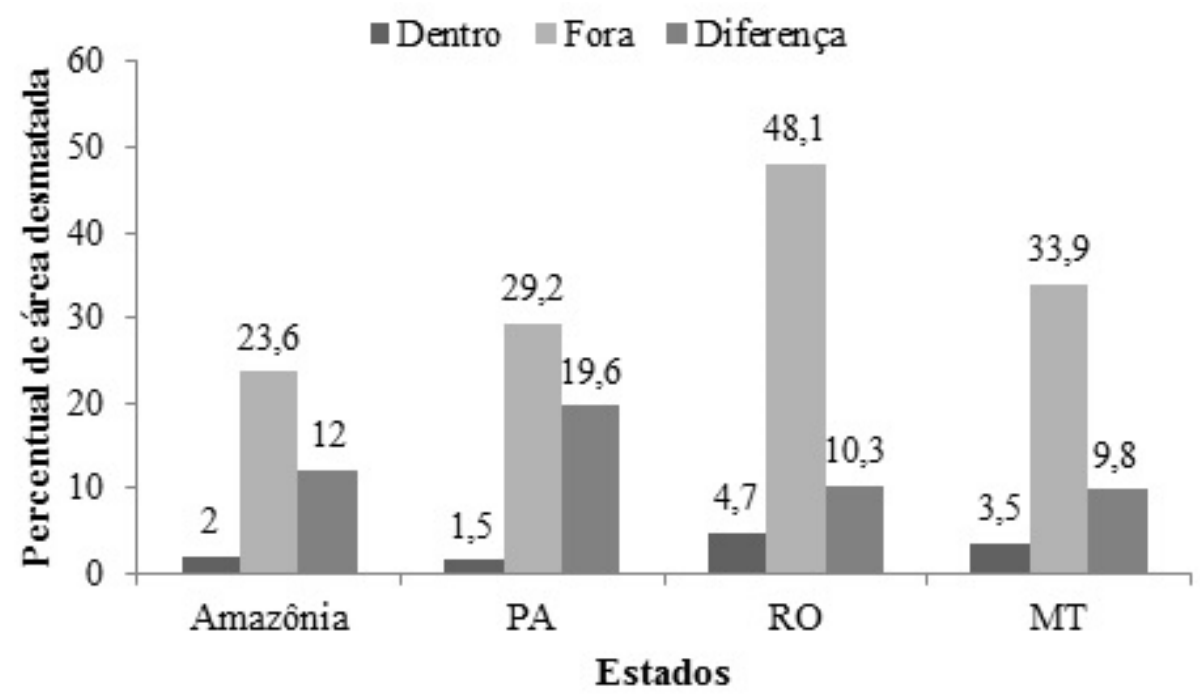

Legenda: Adaptado de Ferreira et al. (2005)

Apesar do expressivo aumento do desmatamento em áreas tropicais, existe pouca informação a respeito desses impactos sobre as comunidades ictíicas (BOJSEN e BARRIGA, 2002). Além disso, é possível que a elevada riqueza de espécies funcione como um tamponador das diferenças reportadas para sistemas temperados, de forma que as teorias e predições desenvolvidas com base nesses sistemas tenham pouca aplicabilidade nas latitudes mais baixas.

Dessa forma, o presente estudo visou comparar a composição e a estrutura de assembleias de peixes de igarapés de áreas que sofreram supressão vegetal e de uma área com presença de cobertura vegetal, compreendida no interior de uma Unidade de Conservação (Reserva Biológica do Jaru - Rebio Jaru) na bacia do rio Machado, na Amazônia brasileira. Nesta abordagem, procurou-se identificar as 
características do hábitat que seriam as mais relevantes na estruturação das ictiocenoses, testando a hipótese de que o tipo vegetacional predominante na microbacia (área de pastagem versus área florestada) exerce um papel determinante na estrutura e composição das assembleias de peixes, onde a abundância e riqueza de espécies é maior nos igarapés localizados na área conservada do que nos igarapés situados na área desflorestada da bacia, e que a composição de espécies e categorias tróficas dos peixes se apresentariam de forma diferenciada para cada uma das áreas analisadas.

\section{Bacia do rio Machado e Área da Reserva Biológica do Jaru}

O presente estudo foi realizado em igarapés localizados na bacia de drenagem do rio Machado, também conhecido como rio Ji-Paraná, situada na porção leste do Estado de Rondônia. A medida que o seu canal principal aumenta de ordem hierárquica, drena áreas com graus médios de alteração, alto e muito alto de alteração ambiental, sendo o trecho médio da bacia, na região central do Estado, o mais desmatado (originalmente com áreas florestadas que foram modificadas em pastagens para atividades de pecuária bovina) (KRUSCHE et al, 2005). Entretanto, no seu trecho final, a partir da confluência com o rio Machadinho, passa a drenar uma área com baixo grau de alteração antropogênica.

A Reserva Biológica do Jaru (Rebio Jaru) apresenta uma área total de 4.773.315,91 ha (PLANO DE MANEJO DA RESERVA BIOLÓGICA DO JARU, 2010) e está localizada nos municípios de Ji-Paraná, Vale do Anari e Machadinho d'Oeste, e faz limite com Theobroma, Ouro Preto do Oeste e Vale do Paraíso, todos estes no Estado de Rondônia e com os municípios de Colniza e Rondolândia, no Estado de Mato Grosso. Na região da Rebio Jaru a precipitação anual é de $2.131 \mathrm{~mm}$ (ANDRADE et al, 2009). O período mais chuvoso ocorre entre os meses de novembro a março (inverno), e o período mais seco, ocorre nos meses de maio a setembro (verão). Os meses de abril e outubro são considerados de transição entre um regime e outro (PLANO DE MANEJO DA RESERVA BIOLÓGICA DO JARU, 2010).

As amostragens foram realizadas nos meses de agosto de 2011 e junho de 2012, totalizando 20 igarapés (10 igarapés na área desflorestada da bacia do rio Machado e 10 igarapés na área florestada da Rebio Jaru) (Figura 2). 
Figura 2 - Localização dos pontos de amostragem na malha hídrica do rio Machado, Rondônia, Brasil.

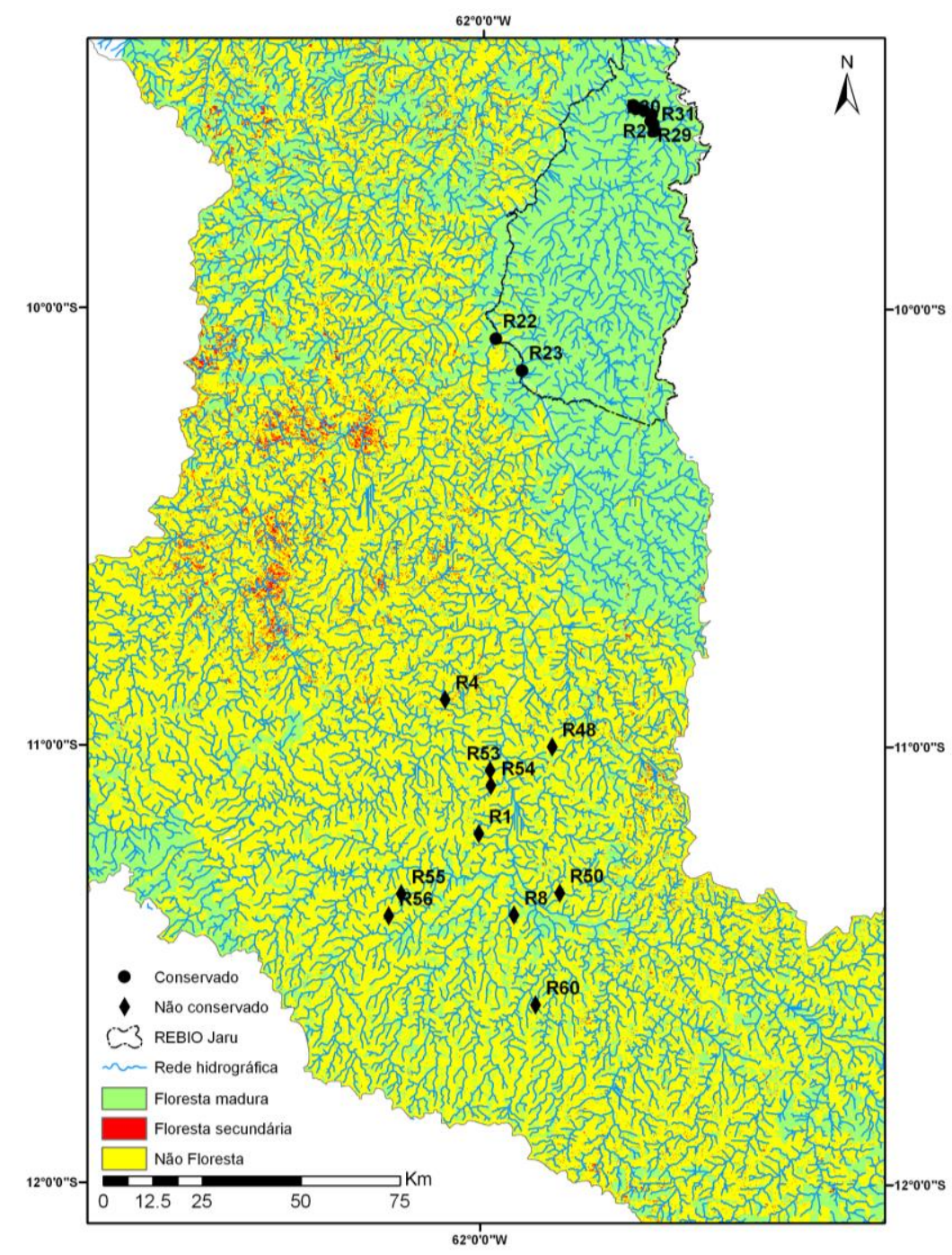

Legenda: $\bullet=$ pontos de coleta desflorestados no trecho médio da bacia $\mathrm{e} \bullet=$ pontos de coleta florestados no interior da Rebio Jaru.

\section{Resultados da pesquisa}

De acordo com a ordenação das amostras no espaço formado pelos dois primeiros eixos da $\mathrm{ACP}$, as duas áreas foram diferenciadas principalmente em relação à elevada presença de gramíneas, algas aderidas, largura, velocidade da correnteza, barranco nu, liteira grossa, liteira ripária, angiospermas arbustivas e raízes grandes em rede (Figura 3). 
Figura 3 - Ordenação das amostras no espaço formado pelos dois primeiros eixos da Análise de Componentes Principais com 20 igarapés.

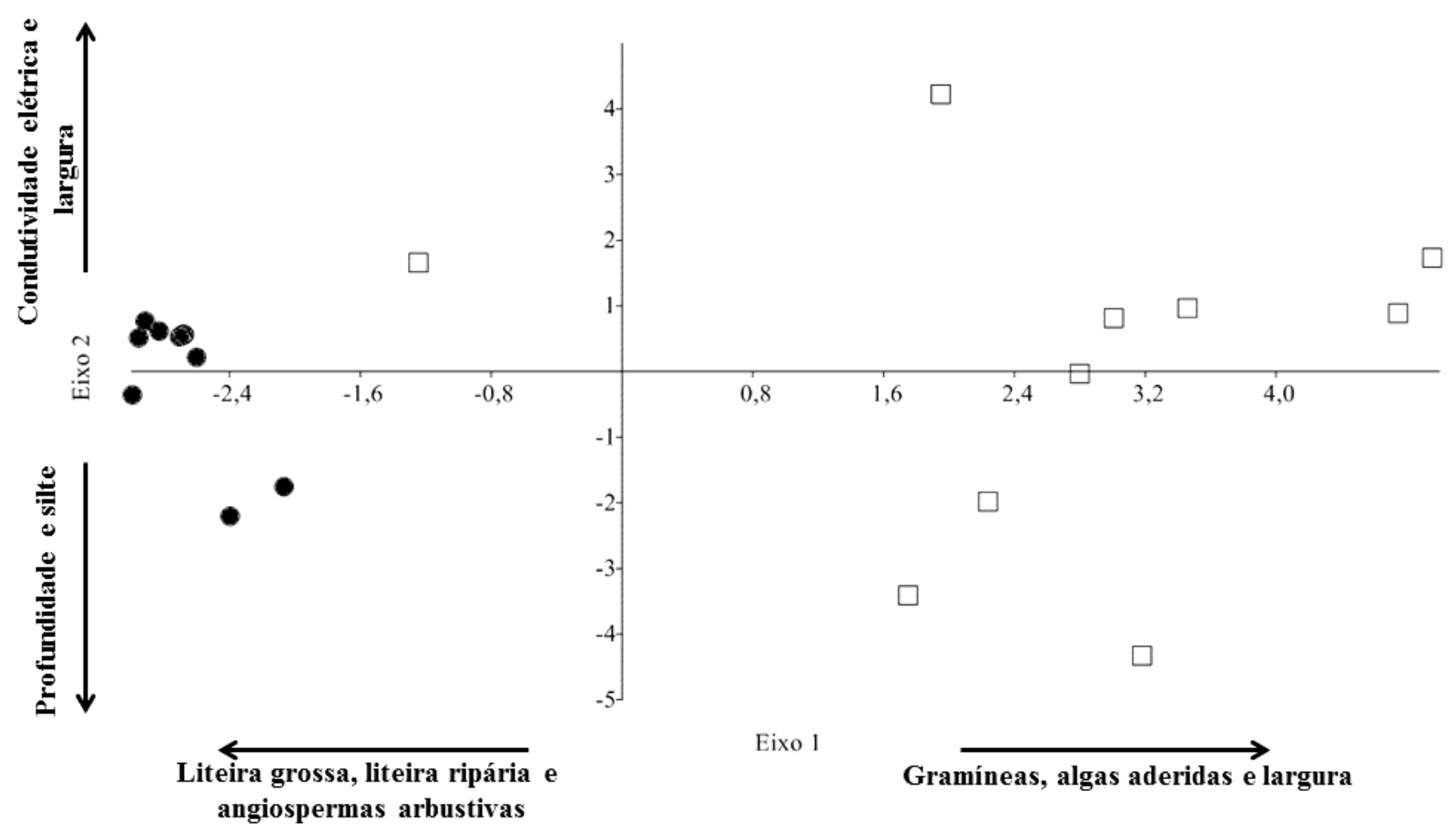

Legenda: • = igarapés localizados na área florestada e $\square=$ igarapés da área desflorestada

Foi coletado um total de 9.254 peixes, pertencentes a 95 espécies, 25 famílias e sete ordens. A área desflorestada da bacia apresentou 4.662 espécimes, distribuídos em 60 espécies, 17 famílias e seis ordens, e a área florestada apresentou um total de 4.592 exemplares, 71 espécies, 22 famílias e seis ordens. Não foram encontradas diferenças significativas para abundância $(\mathrm{t}=-0,82 ; p=0,42)$ e riqueza de espécies $(t=-1,04 ; p=0,30)$ entre as áreas estudadas

Entre as espécies, Serrapinus aff. notomelas ( $n=2353 ; 50,0 \%)$, Serrapinus microdon ( $\mathrm{n}=564 ; 12,1 \%)$, Odontostilbe fugitiva $(\mathrm{n}=278 ; 6,0 \%)$ e Moenkhausia colletti ( $n=205 ; 4,4 \%$ ) foram as mais representativas no trecho desflorestado, sendo Hyphessobrycon agulha ( $\mathrm{n}=823 ; 17,6 \%)$, Bryconella pallidifrons ( $\mathrm{n}=695 ; 15,1 \%)$, Knodus heteresthes $(n=583 ; 12,7 \%)$ e Apistogramma cf. resticulosa $(n=450 ; 9,8 \%)$ as mais abundantes nos igarapés florestados. Para ambas as áreas analisadas, Serrapinus aff. notomelas $(\mathrm{n}=2353 ; 25,5 \%)$, Hyphessobrycon agulha $(\mathrm{n}=823$; $9,6 \%)$ e Bryconella pallidifrons $(n=695 ; 8,1 \%)$ foram as espécies mais abundantes.

Os resultados obtidos em nossa pesquisa indicam que a composição das assembleias de peixes reflete a perda da cobertura vegetal na bacia hidrográfica 
estudada. Tal afirmação baseia-se na observação de uma elevada ocorrência e abundância de espécies de hábitos mais especializados e intolerantes a ambientes com elevado nível de degradação ambiental, como Hyphessobrycon agulha, Apistogramma cf. resticulosa, Ituglanis amazonicus, Helogenes gouldingi, dentre outras, nos igarapés florestados. Isso difere da composição de espécies (ex. Serrapinus aff. notomelas, S. microdon, Aequidens tetramerus) predominantemente encontradas na área desflorestada, que foi composto principalmente por espécies generalistas e tolerantes (TERESA, CASATTI, 2012) as condições, por exemplo, de elevada temperatura, maior presença de algas aderidas e predominância de gramíneas e barranco nu nas região marginal.

As mudanças na composição de espécies ocorreram entre as duas áreas com diferentes níveis de conservação, representando as respostas que são comuns em comunidades aquáticas expostas a gradientes de degradação de habitats (JOHNSON, HERING, 2009).

Com base nos dois primeiros eixos gerados pela Análise de Correspondência (AC) (Figura 4) e no teste de médias realizado com os escores de seu primeiro eixo, observamos a separação $(p<0,001)$ entre os igarapés compreendidos no trecho desflorestado daqueles localizados na área florestada, com base na composição (presença/ausência) de espécies.

Figura 4 - Ordenação dos igarapés da bacia do rio Machado sumarizada a partir de uma $\mathrm{AC}$ (CA1 e CA2 = eixos principais).

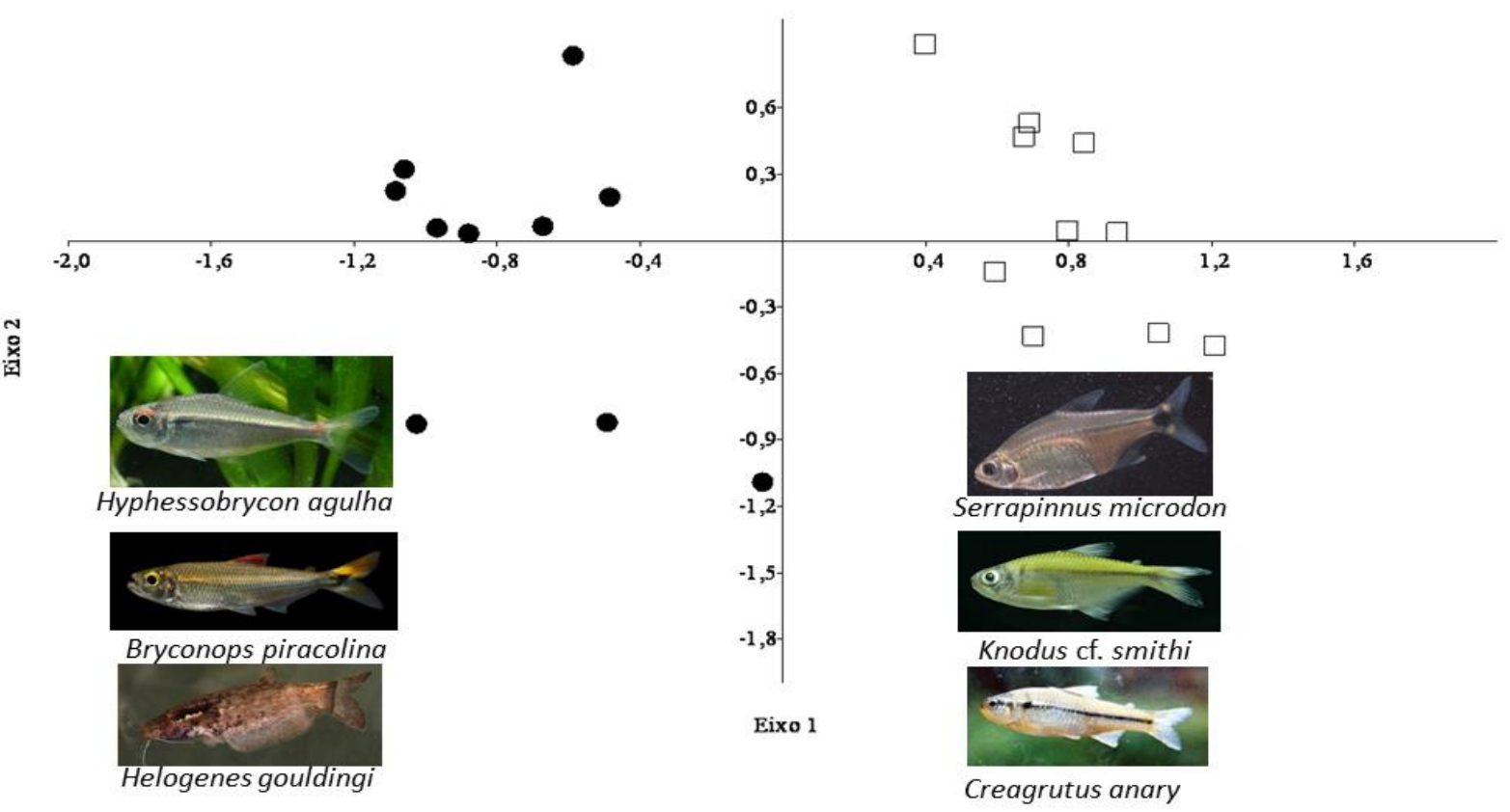

Legenda: $(\bullet$ = igarapés localizados na área florestada $\mathrm{e} \square=$ igarapés da área desflorestada). 
O padrão foi fortemente influenciado pela composição de espécies exclusivas e/ou com elevada ocorrência nos riachos desflorestados (ex. Creagrutus petilus, Knodus cf. smithi, Serrapinnus microdon e S. aff. notomelas) e na área florestada (Helogenes gouldingi, Bryconella pallidifrons, Hemigrammus melanochrous, Hyphessobrycon bentosi e H. agulha).

As assembléis representadas na área da Rebio são tipicamente de ambientes preservados (MATSUZAKI, 2013), sendo que as espécies mais abundantes nesta área são ausentes nos igarapés desfloretados localizados no trecho médio, sendo assim espécies possivelmente indicadoras.

A maioria dessas espécies são dependentes de recursos e condições específicas (ex. disponibilidade de substratos rochosos, presença de troncos e galhos, variabilidade hidráulica e disponibilidade de alimento alóctone carreado para o interior do habitat, níveis elevados de oxigênio e baixa turbidez) (CARVALHO, 2008), comuns em riachos preservados (LORION, KENNEDY, 2009). A perda de meso- e microhabitats é resultante da retirada da cobertura florestal, que provavelmente resultou a ausência destas espécies no trecho desflorestado.

Nove categorias tróficas foram identificadas. Os algívoros, insertívoros, onívoros e perifitívoros foram os mais abundantes em ambas as áreas. Diferenças foram encontradas entre as áreas, tanto para abundância $(F=4,30 ; p=0,04)$ quanto para riqueza de espécies $(F=3,96 ; p=0,04)$. Assim como para a abundância $(F=$ $32,67 ; p=0,0003)$ e riqueza de espécies $(F=57,92 ; p=0,0002)$ de cada categoria trófica. A área desflorestada apresentou maior abundância de algívoros $(p=0,0003)$ e perifitívoros $(p=0,0003)$ quando comprada à área florestada, enquanto esta última apresentou maior abundância de invertívoros $(p=0,02)$. Para a riqueza de espécies, os algívoros $(p=0,00004)$ e perifitívoros $(p=0,006)$ foram predominantes na área desflorestada quando comparada a área com floresta, enquanto esta última apresentou maior riqueza de insetívoros $(p=0,01)$ (Figura 5).

As principais características de peixe de riachos preservados (ex. dieta insetívora, hábito bentônicos, preferência por ambientes correntosos) estão normalmente associados a habitats de corredeiras (CASATTI, CASTRO, 1998) que são mesohabitats comuns em ambientes preservados. Diferentemente, os riachos situados em áreas de pastagem apresentam como principal ameaça a degradação do habitat físico, principalmente através da simplificação do substrato e redução da coluna d'água, ambas consequências da sedimentação excessiva ou assoreamento (CASATTI et al 2006). 
Em nosso estudo, a análise trófica das espécies nas áreas de coleta apontou uma maior riqueza e abundância de espécies algívoras e perifitívoras nos igarapés desflorestados e uma elevada abundância de invertívoros e riqueza de insetívoros na área com maior percentual de floresta.

A densa cobertura vegetal no entorno dos igarapés propicia um ambiente aquático com pouca penetração de luz, resultando em baixa produtividade primária (SANTOS, FERREIRA, 1999). Um dos mais importantes produtores primários em sistemas lóticos é o perifíton (HILL, WEBSTER, 1982 citado por POMPÊO, MOSCHINI-CARLOS, 2003), que constitui uma complexa comunidade de microorganismos (algas, bactérias, fungos, animais, detritos orgânicos e inorgânicos) aderida a um substrato inorgânico ou orgânico, vivo ou morto (WETZEL, 1983).

Mendonça et al (2008) descrevem que os igarapés são cursos d'água pobres em nutrientes, sendo as cadeias alimentares dependentes de material alóctone (animal ou vegetal) proveniente da floresta adjascente, destacando assim a forte relação entre a ecologia trófica das assembléias e a presença de vegetação ripária. Nossos resultados corroboram estudos de PERESSIN (2013) comparando assembleias de peixes de riachos urbanos e não urbanos (sombreados por vegetação) na bacia do rio Paranapanema, Estado de São Paulo, que aponta maior abundância de invertívoros em riachos com vegetação.

Nossos resultados ilustram relações intricadas entre a disponibilidade de alimentos, plasticidade trófica e hábitos de forrageamento das espécies. Sabe-se que substratos como rochas, galhos e troncos são úteis como superfície de crescimento de algas e perifíton e também como abrigos para macroinvertebrados aquáticos. De maneira geral, praticamente todas as espécies ausentes na área desflorestada possuem alguma especialização trófica e costumam ser dependentes do substrato e floresta circundante para o forrageamento. Por outro lado, as espécies que ocorreram apenas na área desflorestada são forrageadores de meia água/superfície, não dependentes do substrato e com alta plasticidade na dieta. 
Figura 5 - Abundância (A) e riqueza de espécies (B) (médiaterro padrão) das categorias tróficas dos peixes coletados na área florestada e desflorestada da bacia do rio Machado.
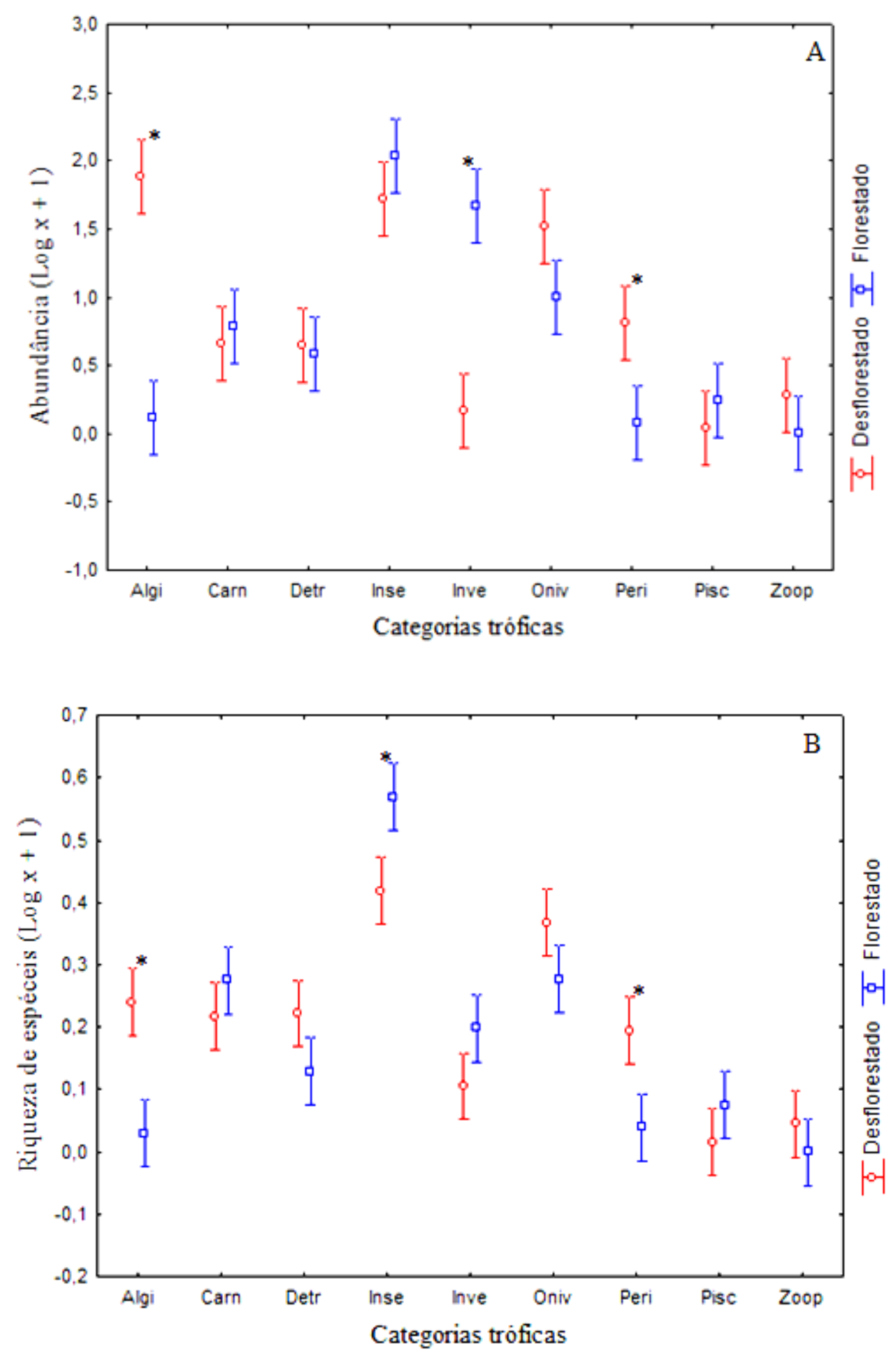

Legenda: Algi = algívoros, Carn = carnívoros, Detr $=$ detritívoros, Inse $=$ insetivoros, Inve $=$ invertívoros, Oniv $=$ onívoros, Peri $=$ perifitívoros, Pisc $=$ piscívoros, Zoop $=$ zooplanctívoros. ${ }^{*}=$ diferenças significativas entre médias 
Resultados similares aos nossos foram encontrados por Casatti et al, (2006), Teresa, Casatti $(2010,2012)$. Como um padrão geral, apontamos que o desmatamento afeta os riachos cuja integridade física e biológica depende da vegetação ripária nativa (PINTO et al. 2006), sendo sua ausência o fator modificador das comunidades aquáticas e funções ecossistêmicas (SWEENEY et al, 2004).

As assembleias de peixes em pequenos rios (primeira até terceira ordem) estão particularmente em risco devido a impactos oriundos de atividades antrópicas, sendo altamente suscetíveis a perda de espécie e redução da diversidade por mudanças induzidas pela urbanização, na qualidade da água, regime hidrológico e estrutura de habitats. Logo, sem o conhecimento de quais espécies vivem nestes sistemas, como elas interagem dentro de ambientes aquáticos altamente modificados ou como a biota responde à urbanização e seus impactos específicos, estaremos despreparados para estabelecer estratégias efetivas de conservação neste ecossistemas.

Concluímos que, apesar da área com pouca vegetação ripária não apresentar diferenças significativas no número de espécies e abundância quando comparada à área conservada, os igarapés desflorestados apresentaram maior repetição de espécies entre si (menor diversidade beta). Igarapés pouco conservados apresentaram homogeneização da sua ictiofauna em comparação com igarapés providos de mata ripária, refletindo a maior homogeneização estrutural encontrada em igarapés com baixo percentual de cobertura vegetal.

\section{Referências}

BOJSEN, B.H.; BARRIGA, R. Effects of deforestation on fish community structure in Ecuadorian Amazon streams. Freshwater Biology, v.47, n.11, p. 2246-2260, 2002.

CARVALHO, L.N. História natural de peixes de igarapés amazônicos: utilizando a abordagem do conceito do rio continuo. 2008. 142f. Tese (Doutorado em Biologia de água Doce e Pesca Interior) - Instituto Nacional de Pesquisas da Amazonia. Manaus, Amazonas, 2008.

CASATTI, L.; CASTRO, R.M.C. A fish community of the São Francisco River headwaters riffles, southeastern Brazil. Ichthyol. Explor. Freshwaters, v.9, p.229-242, 1998.

CASATTI, L.; LANGEANI, F.; SILVA, A. M.; CASTRO, R. M. C. Stream fishes, water and habitat quality in a pasture dominated basin, Southeastern Brazil. Brazilian Journal of Biology, v.66, p.681-696, 2006. 
FEARNSIDE, P.M. Deforestation in Brazilian Amazonia: history, rates and consequences. Conservation Biology, v.19, p.680-688, 2005.

FERREIRA, L.V.; VENTICINQUE, E.; ALMEIDA, S. O. Desmatamento na Amazônia e a importância das aéreas protegidas. Estudos Avançados, v.19, n.53, p.157-166, 2005.

HYNES, H.B.N. The ecology of running waters. Liverpool: Liverpool University Press, 1972.

JOHNSON, R.K.; HERING, D. Response of taxonomic groups in streams to gradients in resource and habitat characteristics. Journal of Applied Ecology, v.46, p. 175-186, 2009.

JUNK, W. J. As águas da Região Amazônica. In: SALATI, E.; SCHUBART, H. O. R.; JUNK, W. J. et al (Orgs.). Amazônia: desenvolvimento, integração e ecologia. São Paulo: Editora Brasiliense, 1983.p. 45-100.

KRUSCHE, A.V.; BALLESTER M. V. R.; VICTORIA R. L.; et al. Efeitos das mudanças do uso da terra na biogeoquímica dos corpos d'água da bacia do rio JiParaná, Rondônia. Acta Amazonica. v.35, n.2, p.197-205, 2005.

LORION, C.M.; KENNEDY, B.P. Riparian forest buffers mitigate the effects of deforestation on fish assemblages in tropical headwater streams. Ecological Applications, v.19, n.2, p.468-479, 1999.

MATSUZAKI, A.A. Levantamento taxonômico da ictiofauna de pequeno porte dos igarapés de terra-firme na estação ecológica do Cuniã, Porto Velho, Rondônia. 2013, 70f. Monografia (Graduação em Biologia) - Universidade Federal de Rondônia, Porto velho, Rondônia, 2013.

MENDONÇA, F.; PAZIN V.; SANTO H. E.; ZUANON J.; MAGNUSSON W. E. Reserva Ducke: A biodiversidade amazônica através de uma grade. Manaus: Áttema Desing Editorial, 2008.p. 60.

MISERENDINO, M.L. CASAUX R.; ARCHANGELSKY M.; DI PRINZIO C.Y.; BRAND C.; KUTSCHKER A.M. Assessing land-use effects on water quality, in-stream habitat, riparian ecosystems and biodiversity in Patagonian northwest streams. Science of the total environment, v.409, n.1, p. 612-624, 2011.

PERESSIN, A. Impactos da urbanização na ictiofauna de riachos da parte superior da bacia do alto rio Paranapanema (SP), Brasil. 2013, 83f. Dissertação (Mestrado em Diversidade Biológica e Conservação) - UFSCAR, Sorocaba, São Paulo, 2013. 
PINTO, B.C.T.; PEIXOTO, M.G.; ARAÚJO, F.G. Effects of the proximity from an industrial plant on fish assemblages in the rio Paraíba do Sul, southeastern Brazil. Neotropical Ichthyology, v.4, n.2, p. 269-278, 2006.

PLANO DE MANEJO DA RESERVA BIOLÓGICA DO JARU. Plano de manejo da reserva biológica do Jaru.1. ed. Brasilia: ICMBIO/MMA, 2010.

POMPÊO, M.L.M.; MOSCHINI-CARLOS, V. 2003. Macrófitas aquáticas e perifíton: aspectos ecológicos e metodológicos. São Carlos: RIMA, 2003.

SANTOS, G.M.; FERREIRA, E.J.G. Peixes da bacia amazônica. In: LOWEMCCONNELL, R.H (Org.). Estudos ecológicos de comunidades de peixes tropicais. São Paulo, Edusp, 1999.

SOARES-FILHO, B.; MOUTINHO P.; NEPSTAD D.; ANDERSON A.; RODRIGUES H.; GARCIA R.; DIETZSCH L.; MERRY F.; BOWMAN M.; HISSA L.; SILVESTRINI R.; MARETTI C. Role of Brasilian Amazon protected áreas in climate change mitigation. Proceedings of the National Academy of Sciences of the United States of America. v.107, n.24, p.10821-10826, 2010.

SWEENEY, B.; BOTT T. L.; JACKSON J. K.; KAPLAN L. A.; NEWBOLD J. D.; STANDLEY L. J.; HESSION W. C.; HORWITZ R. J.; Riparian deforestation, stream narrowing, and loss of stream ecosystem services. Proceedings of the National Academy of Sciences of the United States of America, v. 101, n.39, p. 14132-14137, 2004.

TERESA, F. B. \& CASATTI, L. Importância da vegetação ripária em região intensamente desmatada no sudeste do Brasil: um estudo com peixes de riacho. Pan-American Journal of Aquatic Sciences, v.5, p.444-453, 2010.

TERESA, F.B.; CASATTI, L. Influence of forest cover and mesohabitat types on functional and taxonomic diversity of fish communities in Neotropical lowland streams. Ecology of Freshwater Fish, v.21, p.1-10, 2012.

VERÍSSIMO, A.; ROLLA, A.; VEDOVETO, M.; FUTADA, S.M. Áreas protegidas na Amazônia Brasileira: Avanços e Desafios. 1. ed. Belém: Imazon Socioambiental, 2011.

WETZEL, R. G. Limnology. 2. ed. Saunders, 1983. 


\section{Fundamentos em manejo alimentar de pirarucu}

Jucilene Cavali 3 , Fabio Silva do Carmo Lopes ${ }^{4}$, Acsa Otto Luxinger 5 , Gean Charles Cardoso6, Fabiane Bazzi Rocha 7, Lucas Henrique Vieira de Andrade ${ }^{8}$, Mario Lima9 Marlos Oliveira Porto ${ }^{10}$

\section{Introdução}

O pirarucu ou Gigante da Amazônia é uma das maiores espécies de peixe de água doce do mundo, com ampla distribuição na bacia amazônica, pertencente à família dos Osteoglossídeos. Considerado monotípico como A. gigas Schinz, 1822, por mais de 140 anos, novos registros regem a existência de cinco espécies do gênero Arapaima, distribuídas na América do Sul das quais Castello et al (2013) cita: A. agassizii (Figura 1D) confirmada por estudos de Stewart (2013a), A. mapae (Figura 1B) e $A$. arapaima ou gigas descritas por Valenciennes (1847). A espécie de descrição mais recente da Amazônia Central, a A. leptossoma (STEWART, 2013b) (Figura 1A). A espécie A.gigas (Figura 1C) destaca-se pela abundância na America Latina: Brasil, Peru, Colômbia, Bolívia, Equador e Guiana.

Os estoques pesqueiros naturais do pirarucu vêm sofrendo pressões intensivas devido à pesca comercial. A exploração não sustentável impulsionou a publicação da Instrução Normativa (Instituto Brasileiro do Meio Ambiente e dos Recursos Naturais Renováveis, 2004) que regulamentasse a pesca do pirarucu na Amazônia, proibindo-a em alguns meses do ano e estabelecendo tamanhos mínimos para captura e abate.

\footnotetext{
${ }^{3}$ Dra em Zootecnia. Departamento de Zootecnia da Universidade Federal de Rondônia. jcavali@unir.br ${ }^{4}$ Engenheiro de Pesca. Mestrando em Ciências Ambientais Embrapa/UNIR.

${ }^{5}$ Engenheira de Pesca. Mestranda em Produção de Organismos Aquáticos, UFLA.

${ }^{6}$ Engenheiro de Pesca. Agroindústria Zaltana Pescados.

${ }^{7}$ Engenheira de Pesca. Autônoma.

${ }^{8}$ Bolsista PIBIC/CNPq. Acadêmico em Engenharia de Pesca.

${ }^{9}$ Engenheiro de Pesca. Mestrando em Zootecnia. Instituto Federal Goiano, IFG.

${ }^{10}$ Dr em Zootecnia. Departamento de Zootecnia da Universidade Federal de Rondônia.
} 
Figura 1. Comparação de diferenças morfológicas de espécies de pirarucu: A) Arapaima leptosoma, Sevastopol, Ucrânia. B) Arapaima mapae, INPA. C) Arapaima sp. gigas, INPA, Reserva Mamirauá (Jarauá); D) Arapaima agassizii, Bacia Amazônica, Brasil.

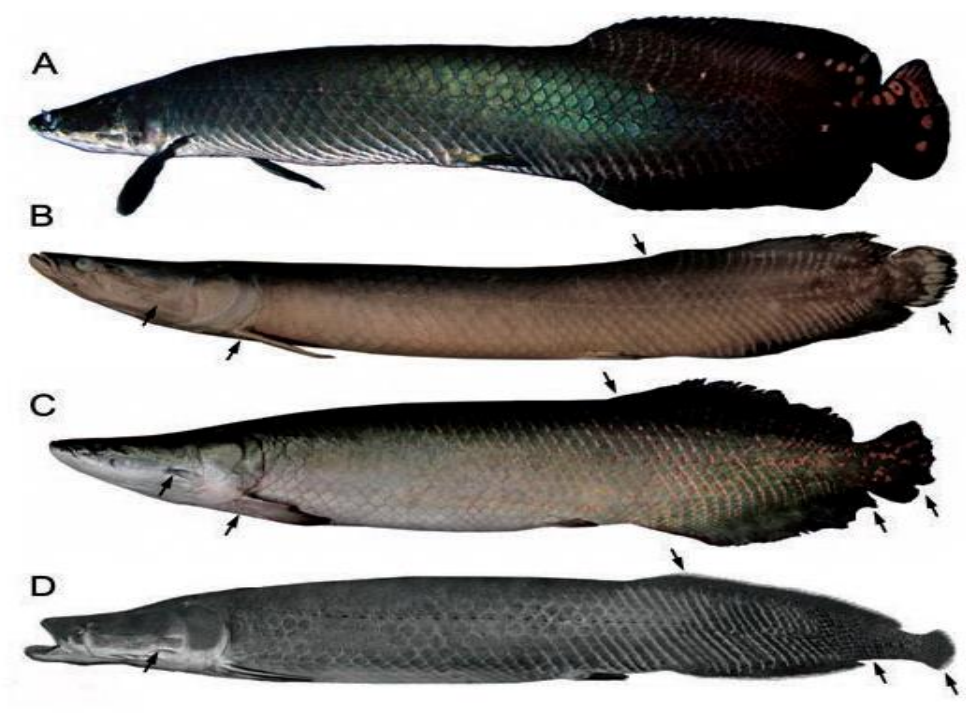

Fonte: adaptado de Castello et al (2013)

Como alternativa a captura nos estoques naturais e em função das características fisiológicas particulares da espécie, o cultivo do Pirarucu em viveiros escavados tem se destacado. Dentre as características deste peixe, destacam-se sua grande rusticidade, notadamente devido a sua respiração predominantemente aérea desenvolvida a medida em que o juvenil cresce e sofre alterações em suas brânquias, especialmente após 6 meses ou 1000 gramas (GOMES, 2007; RAMOS et al, 2013; RAMOS et al, 2014), alta velocidade de crescimento, chegando a alcançar até mais de 10 a $12 \mathrm{~kg}$ em um ano (LOPES, 2015) e, a qualidade e o rendimento de sua carne.

\section{Cultivo do Pirarucu em cativeiro}

Os primeiros cultivos e utilização da reprodução do pirarucu ocorreram por volta de 1948 no Pará (OLIVEIRA, 1944) e Ceará (FONTENELI, 1948). Já maiores estudos do pirarucu iniciaram-se na década de 80 (IMBIRIBA et al. 1986; IMBIRIBA, 2001; IMBIRIBA et al, 2006). No Estado de Rondônia, o primeiro produtor a dedicar- 
se ao cultivo intensivo da espécie em cativeiro e implementar tecnologias de produção de alevinos foi o Sr. Megumi Yokama (Sr. Pedrinho), no Município de Pimenta Bueno.

O cultivo de pirarucu em cativeiro enfrenta entraves que interferem diretamente no planejamento físico-financeiro do piscicultor, como a disponibilidade, qualidade e custo dos alevinos e o manejo nutricional para as fases subsequentes á alevinagem.

\section{Reprodução e disponibilidade de alevinos de qualidade}

O pirarucu é ovulíparo quanto ao tipo de fecundação, ou seja, apresenta a fecundação e o desenvolvimento dos ovócitos externos. Segundo Lopes et al (2013) a maturidade gonadal do Arapaima em ambiente natural é lenta, 4 a 5 anos, está relacionada ao seu comprimento e peso corporal e é influenciada pelas condições estressoras. Nestes ambientes os autores sugerem o início da maturação gonadal (estádio II) e a maturação avançada (estádio IV) a exemplares com $43 \mathrm{~kg}$ e $139 \mathrm{~cm}$ e, $62 \mathrm{~kg}$ e $187 \mathrm{~cm}$, respectivamente, quando a proporção de ovada representa em média $0,75 \%$ do peso corporal. A maturidade sexual pode ser antecipada quando cultivados em viveiros escavados.

Os aspectos do comportamento reprodutivo do Arapaima são complexos, envolve a formação de casais monogâmicos, construção de ninhos, realizam desova parcelada por apresentar oócitos em diferentes estágios de desenvolvimento, em 8 a 12 vezes no ano colocando em média 800 a 2.000 óvulos/desova ou 4 a 5 óvulos g-1 de peso vivo de fêmea (OLIVEIRA et al, 2007) e têm cuidado parental com a progênie (SILVA, DUNCAN, 2016). Segundo Monteiro et al (2010) para a identificação do sexo para formação dos casais, pode-se levar em consideração características visuais como a presença de manchas cor laranja na região inferior da cabeça caracteriza os machos e representa seus perfil hormonal com maior concentração de testosterona. Em cativeiro, uma das disfunções reprodutivas apresentadas parece ser a pouca produção de sêmen sendo esta característica como um dos maiores entraves na reprodução destes animais (NÚÑES et al, 2011). Segundo Silva, Silva, Melo (2015) monitorando 18 matrizes chipadas em 2004 na Piscigranja Boa esperança em Rondônia, a complementação da dieta com peixes forrageiros no período fértil, como o Cará da amazônia, proporcionou estímulo à liberação das larvas de 102 mil para 175 mil de 2014 para 2015. 
A reprodução controlada e a produção de juvenis saudáveis são fundamentais para viabilização do cultivo do Pirarucu em cativeiro. A prevalência de doenças e parasitos é a principal causa de mortalidade na fase de alevinagem da reprodução em cativeiro. $\mathrm{Na}$ maioria das vezes os animais comercializados são clandestinamente capturados enquanto pós larvas em grande lagos e levados a tanques de cultivos para treinamento alimentar, etapas nas quais são infestados por parasitas dentre eles: Monogenoidea (brânquias e pele), Digenea (intestino), Cestodaria (cavidade abdominal), Nematódea (estômago, intestinos, cecos pilóricos e bexiga natatória), Acantocéfala (intestino), Copepoda (narinas), Branchiura (pele), Pentastomida (estomago) e Myxozoa brânquias e nadadeira, conforme relatado por Marinho et al (2015). Tais infestações são potencializadas em função do manejo: elevadas densidades de estocagem, qualidade da agua, uso de produtos inadequados no controle de parasitos.

Segundo Ono et al (2004) a taxa de sobrevivência em um cardume de 5.000 a 6.000 alevinos de 3 a $4 \mathrm{~cm}$ é menor que $10 \%$ em um período de 30 dias. A média obtida no Estado de Rondônia gira em torno de 6\% de sobrevivência. Os índices de mortalidade de alevinos nesta fase inicial, atrelados aos procedimentos do treinamento alimentar na transição zooplactons-ração comercial e ao domínio das exigências nutricionais nesta fase de vida, resultam na oferta de alevinos a um custo elevado aos piscicultores.

Como maioria das espécies carnívoras, o pirarucu demanda treinamento alimentar na transição da ingestão de alimentos vivos para inertes (rações) (CRESCÊNCIO et al, 2001). A eficiência de treinamento rege em torno de $90 \%$. Segundo Ono et al (2004), alevinos com média de $7 \mathrm{~cm}$ fazem a transição zooplacton -ração comercial em cerca de 10 dias e o treinamento alimentar a rações é mais eficaz quando sob altas densidades de estocagem devido o sinergismo ou hábito gregário dos alevinos ser muito expressivo durante o treino alimentar.

A produção de alevinos de pirarucu de qualidade é o principal entrave na produção em escala para atender as pisciculturas, consequentemente as indústrias frigoríficas e o mercado consumidor em expansão.

Dentre as dificuldades para se obter juvenis de qualidade com desempenho semelhante, tem-se a heterogeneidade dos alevinos de um mesmo lote mesmo que submetido ás mesmas condições de manejo (Figura 2).

A heterogeneidade dos lotes pode estar relacionada a fatores como genética,

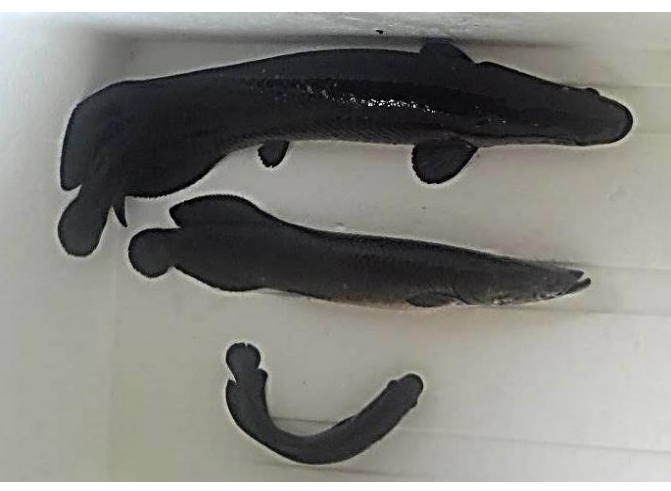


resistência em sanidade, dentre outros. Contudo, mesmo que o produtor adquira alevinos de mesma matriz, a heterogeneidade se apresenta na fase de juvenil, devido as diferentes taxas de crescimento e da presença de animais de comportamento dominante.

A heterogeneidade dos alevinos resulta em animais com diferentes pesos ao abate, atraso dos lotes menores, maior custos de produção e dificuldade de classificação na agroindústria.

\section{Densidade de estocagem}

A densidade de estocagem possui influência direta no consumo e desempenho dos animais, sendo diretamente relacionada a qualidade do alevino e a renovação de água. Apesar do cultivo em tanques-redes ser estudado com maior frequência em função da facilidade de manejo e otimização do uso da ração, os resultados obtidos apresentam-se muito variáveis e na grande maioria os estudos avaliam as fases alevino-juvenil (Tabela 1).

Tabela 1 - Diferentes densidades de estocagem de juvenis de Arapaima gigas

\begin{tabular}{ccccc}
\hline $\begin{array}{c}\text { Densidade de } \\
\text { Estocagem }\end{array}$ & $\begin{array}{c}\text { Peso inicial } \\
(\text { Peso final) }\end{array}$ & $\begin{array}{c}\text { Tempo de } \\
\text { cultivo (dias) }\end{array}$ & $\begin{array}{c}\text { Conversão } \\
\text { Alimentar } \\
\text { Aparente }\end{array}$ & Autor \\
\hline 23 peixes $/ \mathrm{m}^{3}$ & $10 \mathrm{~g}(115 \mathrm{~g})$ & 45 & 1,03 & Cavero et al (2003a) \\
20 peixes $/ \mathrm{m}^{3}$ & $84 \mathrm{~g}(1,0 \mathrm{~kg})$ & 140 & 1,12 & Cavero et al (2003b) \\
& $84 \mathrm{~g}(1,4 \mathrm{~kg})$ & 200 & 1,12 & Oliveira et al $(2012)$ \\
10 a 12,5 & $104 \mathrm{~g}$ & 140 & 1,20 & Luxinger $(2015)$ \\
peixes $/ \mathrm{m}^{3}$ & $(2,6 \mathrm{~kg} \mathrm{e} 2,18 \mathrm{~g})$ & & 2,20 & Ituassú et al $(2005)$ \\
5 peixes $/ \mathrm{m}^{3}$ & $50 \mathrm{~g}(500 \mathrm{~g})$ & 90 & 2,30 & Souza et al $(2009)$ \\
10 peixes $/ \mathrm{m}^{3}$ & $120,6 \mathrm{~g}(355 \mathrm{~g})$ & 45 & 1,2 a 1,6 & \\
3 peixes $/ \mathrm{m}^{3}$ & $2,1 \mathrm{~kg}$ & 210 & &
\end{tabular}

Pode-se constatar que o aumento da densidade de estocagem proporciona maior susceptibilidade a estresse e aumento da mortalidade dos alevinos. Contudo, diferente das demais espécies carnívoras o pirarucu não possui comportamento canibalístico acentuado (IMBIRIBA et al, 2001; LUXINGER, 2015). 
Luxinger (2015) avaliando densidades de estocagem de 2, 4, 6 e 8 juvenis $/ \mathrm{m}^{3}$ em tanques-rede, observou máximo desempenho e conversão alimentar aparente (CAA) de 2,20 na densidade de estocagem de 5 peixes $/ \mathrm{m}^{3}$. Contudo, encontramos na literatura trabalhos com CAA mais elevadas em densidades de estocagem maiores o que reforça a influência da qualidade da água e dos alevinos no sistema de cultivo.

Densidade de estocagem é um severo e agressivo estressor no manejo em piscicultura. Segundo Oliveira et al. (2012), densidades de estocagem de 10 e 12,5 peixes $/ \mathrm{m}^{3}$ afetou o peso final (2.630 vs. $\left.2.138 \mathrm{~g}\right)$ e o ganho de peso (2.516,9 vs. $2043,1 \mathrm{~g})$. Apesar de não influenciar na taxa de crescimento específico (2,25 vs. 2,22 $\% / d i a)$, a CAA $\left(1,2\right.$ vs.1,2) e a produção de biomassa $\left(26,3 \pm 2,1\right.$ e $\left.25,4 \pm 2,6 \mathrm{~kg} / \mathrm{m}^{3}\right)$ as variações do cortisol, glicose, lactato e hematócrito de pirarucus sujeitos as altas densidades foram mais intensas que aquelas obtidas pelo transporte (BRANDÃO et al 2008).

Alevinos de Pirarucu são mais susceptíveis as condições estressoras, também em função da maior demanda pelo $\mathrm{O}_{2}$ aquático nesta fase (SILVA, DUNCAN, 2016), e quando cultivados em tanques-rede apresentam desempenho produtivo inferiores aos alcançados em viveiros escavados.

\section{Manejo alimentar de pirarucu}

\section{Aspectos fisiológicos e nutricionais}

A energia dos alimentos é utilizada na manutenção do metabolismo, locomoção, reprodução e transformação da proteína em crescimento do tecido muscular (FRACALOSSI, CYRINO, 2012). Ao contrário dos animais endotermos, os peixes pecilotérmicos não necessitam gastar energia para controle térmico corporal, além de demandar menor quantidade de energia para locomoção em meio aquático.

Em adição, os peixes gastam menos energia para sintetizar e excretar resíduos nitrogenados visto que até $90 \%$ das excreções de nitrogênio $(N)$ ocorrem na forma de amônia pelas brânquias sendo o restante dos metabólitos excretados pela urina, fezes e pele (descamações) na forma de uréia, ácido úrico e aminoácidos (Figura 3). A excreção da amônia é realizada por difusão facilitada em água, ou seja, diretamente, sem gasto de energia (ATP) porém, dependente do gradiente de concentração da agua. Peixes pulmonados, a exemplo do Pirarucu, podem excretar 
amônia e uréia nos períodos de estiagem ou ambientes estressores relacionados à disponibilidade de agua.

Figura 3. Produtos finais do metabolismo dos aminoácidos em Peixes

\section{Aminoácidos no sangue e tecidos}

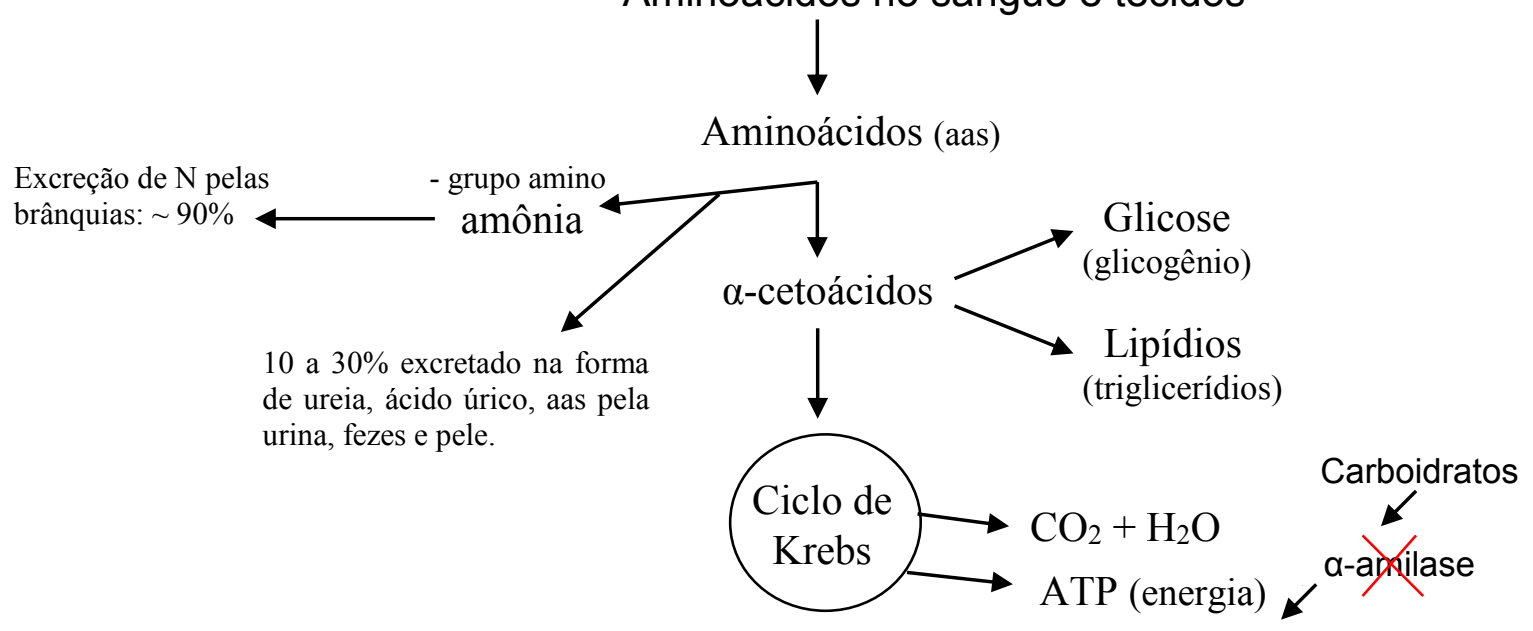

Somado a menor demanda por energia dos peixes, as espécies carnívoras apresentam especificidades no metabolismo enzimático, o que as torna mais dependentes da proteína na dieta aumentando consideravelmente o custo das rações. Segundo relatório prévio do estudo realizado pelo CNA na Cooperativa COOPAMAR em Ariquemes, $84,4 \%$ e $73,7 \%$ do custo operacional efetivo refere-se a ração no cultivo do Pirarucu e Tambaqui, respectivamente. O custo dos ingredientes para fabricação de rações na Região Norte ainda são entraves para diminuir os custos de produção comparados às outras regiões do País.

\section{Exigência de espécies carnívoras e atividade enzimática}

Espécies carnivoras possuem o trato gastrointestinal curto impossibilitando a adequada digestão e absorção dos carboidratos mais complexos, além de apresentarem prejuízos á digestão destes pela deficiência nas enzimas @-amilase (limitada secreção e atividade) e baixa atividade de carboxilases (FURNÉ et al, 2005). A baixa eficiência das espécies carnívoras no aproveitamento de carboidratos (CIPRIANO et al, 2015) as torna mais dependente dos aas para produção de energia (ATP) (Figura 3), quando sob dietas com baixo teor de gorduras. Segundo Furné et 
al, (2005) as espécies carnívoras apresentam elevada atividade de lipases favorecendo a digestibilidade dos ingredientes de origem animal.

Nas reações degradativas dos aas (20 diferentes aas protéicos), após remoção do grupo amino (desaminação dos aas), gerarão diferentes produtos, dependendo do esqueleto de carbono. A glicose é gerada a partir de aas e armazenada na forma de glicogênio (polímero de 8 a 12 unidades de glicose) no fígado e músculo. Os triglicerídeos (glicerol +3 ácidos graxos), podem ter o glicerol originado a partir da glicose ( $1 \mathrm{~mol}$ glicose forma 2 mols de glicerol) e de esqueletos de carbono próprios (Acetil-CoA).

Logo, o desequilíbrio na relação energia proteína da dieta pode acarretar em não aproveitamento dos nutrientes pelo animal (absorção), o aumento considerável da excreção de nitrogênio na água, assim como de outros metabólitos (CYRINO et al, 2010); além de desequilíbrio fisiológico do animal.

A alta relação proteína e baixa energia nas rações permitirá que o animal converta a proteína em energia que, além de favorecer a (glicogênio, TAGs). O excesso de lipídios na dieta resultará em maior acumulo de gordura visceral, menor rendimento de carcaça e ineficiência econômica do sistema de produção.

\section{Digestibilidade dos ingredientes em rações de pirarucu}

Cipriano et al $(2015 ; 2016)$ avaliando a digestibilidade de ingredientes em alevinos de pirarucu com 235 gramas (Tabela 2) observou que os ingredientes de origem vegetal, a base de milho, soja, arroz e trigo, apresentam coeficientes de digestibilidade aparente (CDA) da energia bruta abaixo de $60 \%$, comparado aos ingredientes de origem animal dados pela farinhas de peixe, penas, vísceras e carne e ossos, com CDA acima de $75 \%$, o que se deve a menor capacidade do pirarucu em digerir os ingredientes e obter energia de fontes de origem vegetal. Silva et al (2013) também observaram baixa digestibilidade da proteina do milho para o Surubim.

Ono et al (2008) avaliando pirarucus de 96,8g observou CDA de matéria seca entre 59,3 a $68,3 \%$ para o glúten de milho, farelo de arroz e farelo de trigo, e Braga et al. (2008) avaliando dourados de 33,5g observaram CDA da matéria seca de 95,2 e $95,7 \%$ para as farinhas de peixe e vísceras, respectivamente. 
Tabela 2. Coeficientes de digestibilidade aparente da matéria seca, proteína bruta e energia bruta de ingredientes de origem animal e vegetal em Pirarucu $(235 \mathrm{~g})$

\begin{tabular}{llll}
\hline \multicolumn{1}{c}{ Alimentos } & Matéria seca \% & Proteina bruta $\%$ & Energia bruta \% \\
\hline Farinha de vísceras de aves & $93,46 a \pm 0,58$ & $90,31 b \pm 2,14$ & $96,25 a \pm 1,84$ \\
Farinha de peixe $55 \%$ & $89,19 a \pm 0,18$ & $97,64 a \pm 2,00$ & $89,05 a \pm 8,70$ \\
Farinha de penas hidrolisada & $79,49 b \pm 0,47$ & $80,39 c \pm 2,76$ & $83,34 a \pm 1,25$ \\
Farelo de soja 45\% & $76,71 b \pm 0,38$ & $83,84 b \pm 1,61$ & $58,00 c \pm 5,47$ \\
Fubá de milho & $76,37 b \pm 0,42$ & $93,44 a \pm 3,44$ & $40,10 \mathrm{~d} \pm 5,42$ \\
Farinha de carne e ossos & $70,76 \mathrm{~b} \pm 0,43$ & $89,38 \mathrm{~b} \pm 2,82$ & $75,36 \mathrm{~b} \pm 6,07$ \\
Amido de milho & $70,66 \mathrm{~b} \pm 6,54$ & $90,94 \mathrm{~b} \pm 7,00$ & $47,87 \mathrm{~d} \pm 5,37$ \\
Glúten de milho 20\% & $61,18 \mathrm{c} \pm 0,38$ & $74,22 \mathrm{c} \pm 2,88$ & $59,76 \mathrm{c} \pm 1,26$ \\
Farelo de arroz & $46,23 \mathrm{~d} \pm 2,79$ & $68,23 \mathrm{c} \pm 6,27$ & $42,23 \mathrm{~d} \pm 2,35$ \\
Farelo de trigo & $45,13 \mathrm{~d} \pm 0,08$ & $68,58 \mathrm{c} \pm 2,25$ & $47,37 \mathrm{~d} \pm 3,67$ \\
& $\mathrm{CV} \%=7,21$ & $\mathrm{CV} \%=4,47$ & $\mathrm{CV} \%=7,42$ \\
\hline
\end{tabular}

Fonte: Cipriano et al $(2015 ; 2016)$

Os peixes são capazes de adaptar suas funções digestivas (resiliência) às alterações alimentares (composição e disponibilidade); especialmente àquelas generalistas, capazes de explorar maior variedade de alimentos, importante por aproveitarem um amplo espectro de ingredientes de baixo custo. Menor resiliência das enzimas digestivas existe para espécies carnívoras, ditas especialistas, por ter seu potencial de ganho máximo limitado ao equilíbrio protéico. Silva et al (2013) ao estudar pintados alimentados com diferentes rações que observaram aumentou da produção de @-amilase nas dietas com altos níveis de carboidratos.

Bustos et al (2002) trabalhando com alevinos de pirarucu de 6,5g por 47 dias observaram melhor desempenho e conversão alimentar nas rações com inclusão de farinha de peixes (CAA 2,6) quando comparada a inclusão de farelo de soja (CAA $6,4)$.

Atentar às fontes alimentares é importante e deve-se considerar ainda na relação energia e proteína a fim de favorecer o equilíbrio e explorar o máximo potencial de ganho de peso do animal.

Assim, é de grande importância da formulação adequada da ração com base nas exigências nutricionais espécie-específica considerando: ingredientes acessíveis e com boa digestibilidade, palatabilidade das rações e a relação quanti-qualitativa da proteína. 


\section{Relação energia e proteína bruta nas rações de pirarucu}

A qualidade das rações está relacionada ao atendimento das exigências nutricionais segundo a espécie e idade do animal para o qual deve-se levar em consideração a relação proteína vs. energia na ração, más especialmente o perfil aminoacídico da proteína bruta utilizada na formulação.

O conceito de proteína ideal prevê a inclusão de ingredientes protéicos com perfil de aa's capazes de prover sem excesso ou falta, os requerimentos de todos os aa's necessários para a manutenção animal e a máxima deposição protéica, proporcionando a absorção completa dos aa's pelas células epiteliais sem disputa pelos sítios de absorção. Contudo, os estudos do perfil protéico do Arapaima gigas são incipientes e detêm-se aos níveis de proteína bruta nas rações e restritos as fases de alevinagem e juvenil (Tabela 3).

Tabela 3 - Níveis de Proteína bruta em rações de pirarucu

\begin{tabular}{ccccc}
\hline Fase & Peso inicial-final & $\begin{array}{c}\text { Nível e proteína } \\
\text { bruta (PB) }\end{array}$ & $\begin{array}{c}\text { Conversão } \\
\text { Alimentar } \\
\text { Aparente }\end{array}$ & Autor \\
\hline \multirow{2}{*}{ Alevino/ } & $120,7 \mathrm{~g}-233,2 \mathrm{~g}$ & 33,40 e $46 \%$ & 4,3 & Ituassú et al (2005) \\
Juvenil & $104 \mathrm{~g}-2,4 \mathrm{~kg}$ & $48,6 \%$ & 2,3 & Oliveira et al (2012) \\
& $300 \mathrm{~g}$ & $40 \%$ & 1,20 & Bustos (2002) \\
& $500 \mathrm{~g}-4,1 \mathrm{~kg}$ & $36,38,40,42,45 \%$ & 2,39 & Lopes (2015) \\
Adulto & $2,1 \mathrm{~kg}-7,8 \mathrm{~kg}$ & $36,40 \mathrm{e} 44 \%$ & 1,34 & Souza (2009) \\
& $2,1 \mathrm{~kg}-7,0 \mathrm{~kg}$ & $48 \%$ & 1,52 & \\
\hline
\end{tabular}

Ituassu et al (2005) avaliando níveis de 30, 36, 42 e 48\% de proteína bruta (PB) para juvenis de pirarucu com 120,6 g em tanques-rede de $1 \mathrm{~m}^{3}$ por 45 dias, observaram melhor ganho de peso, taxa de crescimento específico, rendimento de carcaça e conversão alimentar aparente (CAA de 2,3) nos animais que consumiram ração contendo $48 \%$ de proteína bruta (Tabela 3 ).

Souza (2009) avaliando níveis de PB para adultos de Pirarucu obteve conversões baixas e diferenças entre os níveis de PB; Lopes (2015) por sua vez, obteve CAA mais elevadas sem diferenças entre os níveis de PB para juvenis de Pirarucu até os $4,1 \mathrm{~kg}$ aos 100 dias de cultivo em hapas na densidade de estocagem de $10 \mathrm{~kg}$ de biomassa $/ \mathrm{m}^{3}$, demonstrando que estudos em nutrição de pirarucu, 
especialmente na fase adulto são necessários a fim de se conhecer com mais afinco as exigências nutricionais desta espécie carnívora que tem como base dieta protéica de alto custo.

Em o perfil aminoacídico estendendo as exigências em cada fase de vida do animal o equilíbrio proteína e energia deve estar ajustando, ou seja, a relação energia vs. proteína adequada e ajustada a quantidade de ração fornecida pois estes fatores repercutem diretamente na excreção de metabólitos, no desempenho produtivo e no custo de produção de espécies carnívoras.

Pirarucu alimentados com dietas na relação energia vs. proteína de 8 e $9 \mathrm{kcal} / \mathrm{g}$ de proteína resultaram no melhor desempenho zootécnico para o pirarucus mantidos em tanques-rede, durante 210 dias de produção (melhor ganho de peso diário, melhor conversão alimentar aparente e maior consumo e taxa de crescimento específico), não havendo influência das fontes de energia não-protéica (óleo vegetal e gordura animal) (Tabela 4).

Tabela 4. Desempenho de Pirarucu $(2,5 \mathrm{~g})$ em tanques-rede alimentados com diferentes relações ED:PB e duas fontes de energia (OV: oleo vegetal e GA: gordura animal).

\begin{tabular}{|c|c|c|c|c|c|c|c|c|}
\hline \multirow{4}{*}{ Parametros } & \multicolumn{8}{|c|}{ Relação energia digestível / proteína bruta $(\mathrm{kcal} / \mathrm{g}$ ) } \\
\hline & \multirow{2}{*}{\multicolumn{2}{|c|}{$\begin{array}{c}11,0 \\
36 \% \text { PB }\end{array}$}} & \multirow{2}{*}{\multicolumn{2}{|c|}{$\begin{array}{c}10,1 \\
40 \% \text { PB }\end{array}$}} & \multirow{2}{*}{\multicolumn{2}{|c|}{$\begin{array}{c}9,0 \\
44 \% \text { PB }\end{array}$}} & \multirow{2}{*}{\multicolumn{2}{|c|}{$\begin{array}{c}8,0 \\
48 \% \text { PB }\end{array}$}} \\
\hline & & & & & & & & \\
\hline & OV & GA & OV & GA & OV & GA & OV & GA \\
\hline GPD (g/dia) & $22,0 b$ & $20,0 b$ & $24,9 a$ & $26,0 a$ & $24,1 \mathrm{a}$ & $27,4 a$ & $24,3 a$ & $27,1 \mathrm{a}$ \\
\hline $\begin{array}{l}\text { Conversão } \\
\text { Alimentar (CAA) }\end{array}$ & $1,44 b$ & $1,61 b$ & $1,43 b$ & $1,36 b$ & $1,38 a$ & $1,24 a$ & $1,38 a$ & $1,27 a$ \\
\hline $\begin{array}{l}\text { Consumo médio } \\
(\mathrm{kg} / \mathrm{px})\end{array}$ & $6680 b$ & $6792 b$ & $7534 a$ & $7409 a$ & $7000 a$ & $7180 a$ & $7056 a$ & $7100 a$ \\
\hline
\end{tabular}

Fonte: Souza et al (2009)

Geralmente, rações utilizadas na alimentação de peixes carnívoros contêm elevada concentração de proteína animal como farinha de carne e ossos e farinha de peixes, apresentando alto custo e fazendo com que os peixes excretem níveis elevados de fósforo e nitrogênio, contribuindo para eutrofização das águas (KUBITZA, 2003). As rações que eram apenas desenvolvidas para maximizar o crescimento dos peixes, agora devem atender a outras necessidades, como a 
sustentabilidade ambiental no cultivo, o que pode ser atingido pela otimização do uso dos nutrientes nas dietas, utilizando, para isso, um adequado balanço entre a energia e a proteína. Rações que contém relações entre energia e proteína elevadas resultam em menor consumo voluntário pelos peixes (FRACALOSSI, CYRINO 2012) culminando em mais resíduo de ração no meio e eutrofização do viveiro.

\section{Taxas de arraçoamento e frequência alimentar}

A taxa de arraçoamento representa a quantidade de ração fornecida aos peixes. A determinação dessa taxa deve estar associada a taxa de crescimento do animal por meio do ganho de peso e sobra de resíduos. Conhecer a conversão alimentar aparente da espécie em cada fase é fundamental para evitar desperdícios de ração, impactos na qualidade da água e redução de custos. $O$ fornecimento de uma alta taxa de alimentação conduz a ineficiência do metabolismo digestivo, compromete o desempenho de forma direta, piorando a conversão alimentar e, indiretamente, a redução na qualidade da água (SILVA, DUNCAN, 2016), enquanto uma subalimentação causa uma grande competição pelo alimento, dando origem a uma sensível variação no tamanho dos peixes e, conseqüentemente, a uma baixa taxa de crescimento.

Considerando que a taxa de arraçoamento influencia diretamente o crescimento e a eficiência alimentar de uma espécie, estudos das necessidades nutricionais de peixes vem sendo conduzido em termos da melhor taxa de arraçoamento a fim de otimizar o custo do sistema de produção, o ganho de peso e principalmente a qualidade da agua dos sistemas de cultivo. Leopoldino (2015) avaliou 90 pirarucus com peso inicial de $1.6 \mathrm{~kg}$ por 20 dias e observaram CAA variando de 3,13 a 1,96. Os resultados não apresentaram diferenças no ganho de peso através da regressão entre as taxas de arraçoamento (Tabela 5). Contudo, os impactos econômicos e, por consequência, na qualidade da agua devido a eutrofização por resíduos e produção de metabólitos é inferida já nos primeiros 20 dias de estudo.

O metabolismo do Pirarucu reduz com o aumento da idade do animal, assim, a conversão alimentar de alevinos passa de cerca de 1,2 a valores acima de 3,0 quando adultos, na fase de engorda (LOPES, 2015). 
Tabela 5 - Desempenho de pirarucu em diferentes taxas de arraçoamento.

\begin{tabular}{cccccc}
\hline Variáveis & \multicolumn{5}{c}{ Porcentagem de Ração em relação ao Peso corporal } \\
\cline { 2 - 6 } & $4,5 \%$ & $4 \%$ & $3,5 \%$ & $3 \%$ & $2,5 \%$ \\
\hline Ração Fornecida & 6913,2 & 6240,3 & 5445,7 & 4636,1 & 3831,9 \\
Ganho de Peso & 376,67 & 352,22 & 324,58 & 327,78 & 341,67 \\
Conversão Alimentar (CAA) & 3,13 & 3,16 & 3,12 & 2,91 & 1,96 \\
\hline
\end{tabular}

Fonte: Leopoldino (2015)

Assim, deve-se atender as exigências nutricionais de cada fase de modo a aproveitar a taxa de crescimento específico de juvenis, quando são mais eficientes no aproveitamento da proteína e formação de tecido muscular. Subnutrição severa nesta fase, vulgarmente conhecido como "peixe facão" (Figura 4), pode resultar em prejuízos irreversíveis ao piscicultor.

Na fase adulta, a taxa de crescimento é menor, o metabolismo mais lento e a CAA menos eficiente; tal redução é especialmente maior durante as fases finais de desenvolvimento, onde as taxas de crescimento diário são menos elevadas. Assim, é importante avaliar a quantidade e a qualidade de alimento necessário para o cultivo do pirarucu, desde a fase larval até o momento da despesca.

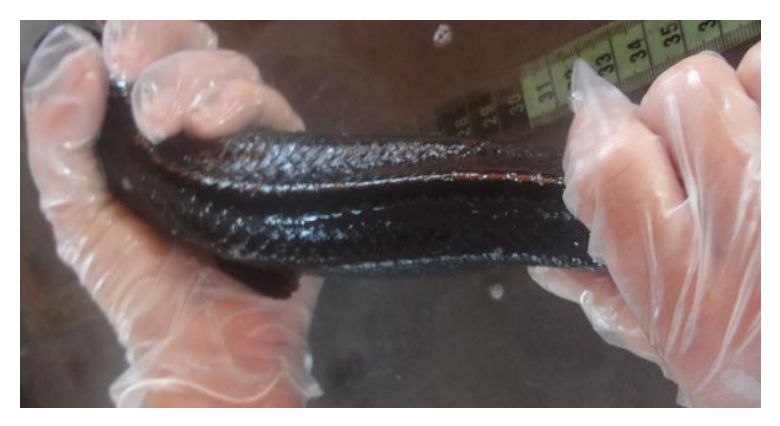

Figura 4. Alevino "facão" de Pirarucu. Arquivo pessoal.

Portanto, para que se otimize a relação custo/benefício no sistema de produção, é necessário considerar, além do custo das rações e alevinos, os aspectos qualitativos e quantitativos da alimentação. O conhecimento da digestibilidade dos ingredientes utilizados na alimentação dos peixes é de fundamental importância porque permite a formulação de alimentos mais eficientes, resultando em melhor aproveitamento dos nutrientes, otimização dos custos de alimentação e aumento da produtividade e rentabilidade do produtor. 


\section{Referências}

BRANDÃO, F.R.; GOMES, L.C.; CRESCÊNCIO, R.; CARVALHO, E.S. Use of salt during the transportation of Arapaima gigas juveniles (1 kg). Acta Amazonica, v. 38, n. 4, p. 767-772, 2008.

BUSTOS O. E. Evaluación de tres niveles, 35, 40 y 45\% de proteína en el pirarucú (Arapaima gigas) durante la etapa de alevinaje, con harina de pescado y/o torta de soya como fuentes de proteína. Tesis Zootecnia Universidad Nacional de Colombia. Bogotá D. C. 2002.

CASTELLO, L.; STEWART, D.J., ARANTES, C.C. O que sabemos e precisamos fazer a respeito da conservação do pirarucu (Arapaima spp.) na Amazônia. In: FIGUEIREDO, E.S.A. Biologia, conservação e manejo participativo de pirarucus na Pan-Amazônia. Tefé: IDSM, 2013. 278p.

CAVERO, B.A.S.; PEREIRA-FILHO, M.; ROUBACH, R.; ITUASSÚ, D.R.; GANDRA, A.L. 2003a. Efeito da densidade de estocagem na homogeneidade do crescimento de juvenis de pirarucu em ambiente confinado. Pesquisa Agropecuária Brasileira, v.38, p. 103-107.

CAVERO, B.A.S.; ITUASSÚ, D.R.; PEREIRA-FILHO, M.; ROUBACH, R. Uso de alimento vivo como dieta inicial no treinamento alimentar de juvenis de pirarucu. Pesquisa agropecuaria brasileira, v. 38, n. 8, p. 1011-1015, 2003b.

CIPRIANO, F. D.S., LIMA K.S., SOUZA R.H.B., TONINI W.C.T., PASSINATO E.B., BRAGA L.G.T. Digestibility of animal and vegetable protein ingredients by pirarucu juveniles, Arapaima gigas. Revista Brasileira de Zootecnia. v.45, n.10. p.581-586, 2016.

CIPRIANO, F. D.S., LIMA K.S., PASSINATO E.B., JESUS, R.M., MAGALHÃES JR, F.O., TONINI W.C.T., BRAGA L.G.T. Apparent digestibility of energetic ingredients by pirarucu juveniles, Arapaima gigas (Schinz, 1822). Short Communication. Latin American Journal Aquatic Research. v.43, n.4. p.786-791, 2015.

CYRINO, J.E.P., BICUDO, A.J.A., SADO, R.Y., BORGHESI, R., DAIRIKI, J.K. A piscicultura e o ambiente - o uso de alimentos ambientalmente corretos em piscicultura. Revista Brasileira de Zootecnia, v.39, p.68-87, 2010 (supl. especial)

CRESCÊNCIO, R. 2001. Treinamento alimentar de alevinos de pirarucu, Arapaima gigas (Cuvier, 1829), utilizando atrativos alimentares. Dissertação de Mestrado. 
Instituto Nacional de Pesquisas da Amazônia/Fundação Universidade do Amazonas. Manaus, Amazonas. 35p.

FURNÉ, M., HIDALGO, M.C., LOPEZ, A., GARCIA-GALLEGO, M., MORALES, A.E., DOMERZAIN, A., DOMEZAINE J., SANZ, A. Digestive enzyme activities in Adriatic sturgeon Acipenser naccarii and rainbow trout Oncorhynchus mykiss. A comparative study, Aquaculture, 250, 391-398. 2005.

FRACALOSSI, D.M. CYRINO, J.E.P. NUTRIAQUA: nutrição e alimentação de espécies de interesse para a aquicultura brasileira. $1^{\text {a }}$ ed. Florianópolis: Sociedade Brasileira de Aquicultura e Biologia Aquática, 375 p. 2012.

GOMES, L. C. Physiological responses of pirarucu (Arapaima gigas) to acute handling stress, Acta Amazonica v. 37, n.4. p. 629 - 634. 2007

FONTENELE, O. Contribuição para o conhecimento da biologia do pirarucu, Arapaima gigas (Cuvier), em cativeiro (Actinopterygii, Osteoglossidae). Revista Brasileira de Biologia, Rio de Janeiro, v.8, n. 4, p. 445-459, 1948.

IMBIRIBA, E.P., Potencial da criação de pirarucu, Arapaima gigas, em cativeiro. Acta Amazônica, Manaus 31, 299-316. 2001.

IMBIRIBA, E. P.; BARD, J.; MOURA CARVALHO, L. O. D. de; NASCIMENTO, C. N. B.; SOUZA, J. C. M. Resultados preliminares de criação do pirarucu, Arapaima gigas (Cuvier) em cativeiro. Belém: EMBRAPA-CPATU. 1986.4 p.

ITUASSU, D.R., PEREIRA FILHO, M., ROUBACH, R., CRESCÊNCIO, R., CAVERO, B.A.S., GANDRA, A. L., Níveis de proteína bruta para juvenis de pirarucu. Pesquisa Agropecuária Brasileira, v.40, 255-259. 2005.

KUBITZA, F. 2003. Qualidade da água no cultivo de peixes e camarões. 1. ed. Jundiaí: F. Kubitza. 229 p.

LEOPOLDINO, F.B. Taxas de arraçoamento para juvenis de pirarucu (Arapaima gigas) cultivado em viveiro escavado. Trabalho de Conclusão de Curso - TCC. Departamento de Engenharia de Pesca: UNIR. 52p. 2015

LOPES, F.S.C. Desempenho produtivo e econômico de pirarucu (Arapaima gigas) em diferentes sistemas de alimentação proteicos. Trabalho de Conclusão de Curso TCC. Departamento de Engenharia de Pesca: UNIR. 54p. 2015.

LOPES, K., ROCHA, R., FERREIRA, M.A.P., QUEIROZ, H.L. Nota sobre a biologia reprodutiva do pirarucu Arapaima gigas Schinz 1822. In: FIGUEIREDO, E.S.A. Biologia, conservação e manejo participativo de pirarucus na Pan-Amazônia. Tefé: IDSM, 2013. p.43-58. 
LUXINGER, A.O. Densidade de estocagem de alevinos de pirarucu (Arapaima gigas) cultivados em tanques-rede. Trabalho de Conclusão de Curso - TCC. Departamento de Engenharia de Pesca: UNIR. 49p. 2015.

MARINHO, R.G.B, TOSTES, L.V., BORGES, M., OBA-YOSHIOKA, E.T., TAVARESDIAS, M. Respostas hematológicas de Arapaima gigas (Pisces: Arapaimidae) parasitados naturalmente por protozoários e metazoários. Biota Amazônia. v.5, n.1, p.105-108, 2015.

MONTEIRO, L.B.B, SOARES, M.C.F., CATANHO, M.T.J.; HONCZARYK A. Aspectos Reprodutivos e Perfil Hormonal dos Esteróides Sexuais do Pirarucu, Arapaima gigas (SCHINZ,1822), em Condições de Cativeiro. v40, n.3. p 435 - 450. 2010.

NÚÑES, J.; CHU-KOO, F.; BERLAND, M.; ARÉVALO, L.; RIBEYRO, O.; DUPONCHELLE, F.; RENNO, J.F. Reproductive success and fry production of the paiche, Arapaima gigas (Schinz), in the region of lquitos, Perú. Aquaculture Research, n. 42, pg. 815-822, 2011.

ONO, E.A.; HALVERSON, M.R.; KUBITZA, F. Pirarucu, O Gigante Esquecido. Panorama de Aquicultura, 14:14-25. 2004.

ONO, E.A., NUNES, E.S.S., CEDANO, J.C.C., PEREIRA FILHO, M., ROUBACH, R. Digestibilidade aparente de dietas práticas com diferentes relações energia: proteína em juvenis de pirarucu. Pesquisa Agropecuária Brasileira, 43, 249-254. 2008.

OLIVEIRA, C.E. Piscicultura amazônica. A voz do Mar. Rio de Janeiro, v. 23 n 188, p. 104-106, 1944.

RAMOS, C.A., FERNANDES, M.N., COSTA, O.T.F., DUNCAN W.P. Implications for osmorespiratory compromise by anatomical remodeling in the gills of Arapaima gigas. The anatomical record 296:1664-1675. 2013.

RAMOS, C.A.; RAULINO, J.C.N.; MENEZES, G.C.; CARMO, I.B.; BRASIL, E.M.; AFFONSO, E.G.; COSTA, O.T.F.; FERNANDES, M.N. Influences of Amazonian White and Black Waters on the hematological and biochemical plasma features of Arapaima gigas (Osteoglossiformes). Journal of Life Sciences, v. 8, n. 3, p. 252-261, 2014.

ROUBACH, R.; PEREIRA FILHO, M. 2003. Pirarucu production: advances in Central Amazon, Brazil, Global Aquaculture Advocate, v.6: 44-46.

SILVA, E.G.O., SILVA, E.S., MELO, G.M.P. Inducão de desovas da matriz do Arapaima gigas criada em cativeiro na piscigranja boa esperança nos municipios de 
Pimenta Bueno e Primavera no estado de Rondônia. Anais... Encontro de PósGraduação e IX Encontro de Iniciação Científica, 3. 2015.

SILVA, T.S.C., MORO, G.V. SILVA, T.B.A. DAIRIKI, J.K. CYRINO J.E.P. Digestibility of feed ingredients for the striped surubim Pseudoplatystoma reticulatum. Aquaculture Nutrition, v.19, p.491-498. 2013.

SOUZA, R.T.Y.B., OLIVEIRA, S.R., JUNIOR, E.A.S., ONO, E.A., ROUBACH, R. AFFONSO, E.G. Avaliação do desempenho produtivo do pirarucu, Arapaima gigas, alimentado com diferentes dietas em sistema intensivo de tanques-rede. Anais... ZOOTEC - Associação Brasileira de Zootecnia. 2009.

STEWART, D.J. Re-description of Arapaima agassizii (Valenciennes), a Rare Fish from Brazil (Osteoglossomorpha: Osteoglossidae). Copeia: March 2013, v.1:38-51. 2013a.

STEWART, D.J. A New Species of Arapaima (Osteoglossomorpha: Osteoglossidae) from the Solimões River, Amazonas State, Brazil. Copeia: September 2013, v.3:470476. 2013b.

TAVARES-DIAS, M. 2009. Manejo e sanidade de peixes em cultivo [recurso eletrônico]Marcos Tavares-Dias, Organizador. Macapá: EMBRAPA AMAPÁ, 2009. CD-ROM.

\section{Agradecimentos}

A Nutrizon Alimentos LTDA e Piscicultura Boa Esperança pelo apoio ao desenvolvimento das pesquisas 


\section{Nutrição e alimentação de tambaqui}

Marlos Oliveira Porto ${ }^{11}$, Aline Ribeiro Almeida ${ }^{12}$, Cleanderson Ferreira Carvalho ${ }^{13}$, Jeferson Jose Machado ${ }^{14}$, Carlos Roberto Moraes $\mathrm{Jr}^{15}$, Newmar Tavares Dias Soares $^{16}$, Elvino Ferreira ${ }^{17}$, Jucilene Cavali ${ }^{18}$

\section{Introdução}

O tambaqui (Colossoma macropomum, Cuvier, 1818) é a principal espécie cultivada e comercializada na Amazônia, sobretudo no estado de Rondônia (PINHEIRO et al 2014).

\section{Tambaqui (Colossoma macropomum)}

O Tambaqui, Colossoma macromomum pertencente à família Serrasalmidae e à subfamília Serrasalminae. Este peixe é considerado de piracema, nativo das bacias dos rios Solimões, Amazonas e Orinoco, sendo amplamente distribuído na parte tropical da América do Sul e na Amazônia Central, e muito apreciado pelo sabor, sendo importante fonte de proteína animal (ARAÚJO-LIMA, GOULDING, 1998). A espécie apresenta excelente desempenho para cultivo em diferentes sistemas de criação intensiva (CHELLAPA et al 1995; MELO et al 2001), possui rápido crescimento e alta eficiência alimentar. A dieta natural do tambaqui inclui zooplânctons, frutos e sementes, sendo considerado um onívoro com tendência a frugívoro.

\footnotetext{
${ }^{11}$ Médico Veterinário, Dr. em Zootecnia. Departamento de Zootecnia da Universidade Federal de Rondônia. marlosporto@unir.br

${ }^{13}$ Engenheira de Pesca. Autônoma

${ }^{13}$ Engenheiro de Pesca. Agroindústria Peixes da Amazônia. Acre.

${ }^{14}$ Engenheiro de Pesca. Autônomo

${ }^{15}$ Engenheiro de Pesca. Trovão Consultoria.

${ }^{16}$ Bolsista PIBIC/CNPq. Acadêmico em Engenharia de Pesca

${ }^{17}$ Zootecnista, Dr em Zootecnia. Departamento de Medicina Veterinária, UNIR.

${ }^{18} \mathrm{Dr}^{\mathrm{a}}$ em Zootecnia. Departamento de Zootecnia da Universidade Federal de Rondônia.
} 
Essa espécie atinge a maturidade sexual entre o terceiro e o quarto ano de vida, apresenta desova total, alta fecundidade e ovos semipelágicos (ARAÚJO-LIMA, GOULDING, 1998).

Pelos fatores supracitados, o tambaqui tem sido o peixe de escolha para cultivo na região norte do país. A espécie atingiu a produção de aproximadamente 54,3 mil toneladas em 2010 , crescimento de cerca $40 \%$ em relação ao produzido em 2008 (MPA, 2012).

Sabe-se que a alimentação é responsável pela maior fração dos custos, dentro do sistema de produção, podendo em cultivos intensivos de tambaqui representar até $60 \%$ dos custos de produção (MELO et al 2001; IZEL, MELO, 2004; GOMES et al 2006).

\section{Nutrição e Alimentação}

Conhecer a composição química e o valor nutritivo dos alimentos que podem compor uma dieta e utilizar o manejo alimentar adequado para cada sistema de criação, adaptado de acordo com a espécie e a fase de produção, é fundamental para o sucesso do sistema de cultivo (FURUYA, 2001).

A nutrição é o conjunto de processos que vão desde a ingestão do alimento até a sua assimilação pelas células nos diferentes tecidos. Entende-se por alimentação, o ato ou efeito de alimentar os peixes. O conhecimento dos hábitos alimentares dos peixes é importante para o fornecimento de rações, uma vez que auxilia na determinação das necessidades nutricionais de cada espécie.

Entre os vários fatores que contribuem para a nutrição de peixes, destaca-se o fato de dependerem direta e indiretamente do meio onde vivem, estando sujeitos às condições ambientais, de difícil manipulação e que podem influenciar na eficiência de uso das rações.

Rações que apresentam altos teores energia em relação à proteína pode levar o peixe à saciedade, sem que estes ainda não tenham suprido as necessidades em proteína ou outros nutrientes e, desta forma, não expressam o máximo potencial de ganho muscular, podendo, ainda acumular gordura na carcaça e nas vísceras. Por outro lado, quando a ração tem pouca energia em relação à proteína, ao se saciarem, muita proteína é ingerida, não havendo na ração energia suficiente para transformá-la em tecido muscular. Neste último caso, parte da proteína em excesso será utilizada como energia, aumentando os custos da ração e fazendo com que o 
nitrogênio da sua composição seja excretado, aumentando a poluição do meio aquático (SANTOS, 2013).

A quantidade de proteína bruta $(\mathrm{PB})$ recomendada em termos práticos para tambaqui tem variado de 20 a $40 \%$ de $\mathrm{PB}$, de acordo com a fase da vida produtiva do animal, sendo os teores mais elevados para alevinos, os intermediários para juvenis e os menores teores de proteína bruta para animais em fase de engorda, rações com cerca de $20 \%$ de proteína bruta tem sido utilizado no cultivo da espécie no Peru.

A alimentação dos peixes estocados nos tanques-rede, por sua vez, é ainda mais importante devido ao regime de confinamento em que os animais são submetidos, sendo o acesso limitado à produção primária do meio aquático, deve suprir todas as necessidades nutricionais das espécies, essas dietas dependerão da espécie a ser cultivada. A qualidade da ração é um fator limitante para o cultivo. Alimentos de baixa qualidade possuem menor estabilidade na água, consequentemente, maior carga poluente, reduzindo o desempenho animal devido a dissolução dos nutrientes na água. Já a ração de alta qualidade possui maior estabilidade na água, menor carga poluente e promove uma maior produtividade (NASCIMENTO, 2010).

\section{Fatores que afetam o consumo de ração}

Alguns fatores podem interferir no consumo de ração pelos peixes como o sistema de cultivo em viveiros ou tanques-rede, a qualidade dos alevinos, o valor nutricional da dieta (proteína e energia), o fotoperíodo, a sanidade e o manejo, além da qualidade da água.

\section{Sistema de cultivo}

O sistema de cultivo em viveiro escavado ou tanques-rede é de grande importância para o cultivo do Tambaqui, em função das densidades de estocagem adotadas nestes sistemas, mas especialmente devido à espécie não apresentar desempenhos satisfatórios, quando adultos, sob cultivo em tanques-rede (CARVALHO, 2015).

As vantagens dos tanques-redes são diversas como a possibilidade de uso racional dos recursos hídricos, escalonamento da produção, possibilidade de uso de lâminas impróprias para cultivos intensivos, facilidade no monitoramento e manejo, 
controle eficiente da população e da sanidade, facilidade na despesca e permite o confinamento de peixes na quantidade adequada onde serão alimentados até atingirem o peso de comercialização (CODEVASP, 2013). Os comedouros instalados dentro dos tanques redes são de fundamental importância para que o alimento ofertado não se disperse sendo eficientemente consumido e monitorado quanto as sobras. A criação do tambaqui em tanques-rede é uma alternativa para as propriedades rurais que possuem pequenos lagos e açudes. $O$ sistema de cultivo em tanque-rede possibilita ainda a observação diária dos peixes, facilita o manejo como a avaliação biométrica, e intensifica a produção, trazendo mais rentabilidade para o produtor.

Rodrigues (2014) fez uma revisão e observou variação na frequência ideal de alimentação para tambaquis na faixa de peso de 55 a 1000 gramas, sendo esta frequência também influenciada pelo local de cultivo, viveiros escavados ou tanquesrede (Tabela 1). Observou-se ainda neste estudo a falta de informação para tal variável, para peixes na fase de engorda em tanques-rede, provavelmente, devido ao maior custo nas pesquisas com animais de maior porte e pela baixa eficiência alimentar da espécie neste tipo de cultivo, uma vez que o acesso à produção primária fica limitado, retirando uma das grandes vantagens da espécie.

Tabela 1 - Frequência de alimentação para tambaqui em viveiros escavados e tanques-rede

\begin{tabular}{|c|c|c|c|}
\hline Peso médio (g) & $\begin{array}{c}\text { Proteína bruta } \\
(\%)\end{array}$ & $\begin{array}{c}\text { Frequência de } \\
\text { alimentação ao dia }\end{array}$ & Referências \\
\hline \multicolumn{4}{|c|}{ Viveiros escavados } \\
\hline Alevinagem & 34 & 4 & IZEL, MELO, 2004 \\
\hline 100 a 500 & 28 & 2 & \\
\hline 500 a 1000 & 28 & 2 & \\
\hline$>1000$ & 28 & 1 & \\
\hline \multicolumn{4}{|c|}{ Tanque-rede } \\
\hline $1-3$ a $20-40$ & 34 & 3 & SILVA et al 2007 \\
\hline 55,55 a 200 & 34 & 3 & CHAGAS et al 2005 \\
\hline$>200$ & 28 & 2 & CHAGAS et al 2007 \\
\hline
\end{tabular}

Fonte: Rodrigues (2014)

A densidade de estocagem é um dos fatores críticos, para que se possa desempenhar o potencial genético dos alevinos na criação em tanques- redes, estando diretamente ligadas as Boas Práticas de Manejo, podendo ser evitados muitos problemas como o estresse (PORTO, 2005). O uso de densidades de $\sim 41 \sim$ 
estocagem adequadas pode reduzir a produção de amônia, aumentar o ganho/ $\mathrm{m}^{3} \mathrm{de}$ água e a rentabilidade do piscicultor.

A quantidade de peixe a ser produzida dependerá da espécie e da região. Em sistema de produção super-intensivo apenas uma espécie é cultivada em alta densidade, chegando a produzir até 200 peixes $/ \mathrm{m}^{3}$ de água. Os resultados positivos em cultivos comerciais de peixes dependem do alimento fornecido para as espécies, que devem ser balanceados em todos os nutrientes. A dieta influencia o comportamento, a integridade estrutural, saúde, funções fisiológicas, a reprodução e o crescimento dos peixes.

Peixes criados em baixas densidades de estocagem apresentam alta taxa de crescimento e porcentagem de sobrevivência, porém a produção por área é baixa (GOMES et al 2000), e peixes mantidos em altas densidades, normalmente, têm menor crescimento além de reduzir as taxas de conversão alimentar, propiciar o canibalismo das nadadeiras dorsais, a redução da condição física, o incremento da competição e a piora da qualidade da água. Desta forma, a densidade de estocagem torna-se um fator crítico para o adequado desempenho dos alevinos na criação em tanques- redes estando diretamente ligada às boas práticas de manejo, podendo ser evitados muitos problemas como o estresse, quando se conhece a densidade de estocagem da espécie (PEDRAZZANI et al 2007). Para alevinos a partir de 10 gramas de peso corporal, quanto maior o nível de proteína bruta na ração, maior a produção por volume de água utilizado, no entanto, são maiores os custos e menor retorno do capital investido, durante um período de 30 dias, onde o nível mais rentável foi o de $32 \%$ de $\mathrm{PB}$, sendo este o recomendado para esta fase de peixes criados em tanque rede (ALMEIDA, 2014), semelhante ao valor encontrado por Melo et al (2001).

\section{Qualidade dos alevinos}

A qualidade de um alevino em sistemas de produção mais intensivos relaciona-se, principalmente, ao máximo desempenho deste alevino nas condições nutricionais e de manejo impostas. O máximo desempenho atrela-se a genética e resistência a doenças e parasitos, que interferem, diretamente, na obtenção de lotes mais homogêneos durante o cultivo. Lotes homogêneos compostos por alevinos saudáveis e que apresentam adequado desempenho produtivo propiciam ao piscicultor, ciclos de cultivos mais curtos, rápido retorno econômico. 
Alevinos de qualidade ruim, normalmente, refugos de lotes heterogêneos, relacionam-se a idades mais avançadas e prejuízos fisiológicos á boas conversões alimentares e, principalmente, a eficiência de ganho em tecido proteico na carcaça, onde o rendimento para produção de filé é reduzido em função das estruturas ósseas e tecido gorduroso, ou seja, aumento de resíduos como vísceras, cabeça, peso da pele e escamas dentre outros.

O consumo de alimento de um organismo animal diminui proporcionalmente ao seu peso à medida que ele cresce; tal redução é especialmente maior durante as fases iniciais de desenvolvimento, onde as taxas de crescimento diário são mais elevadas. Assim, é importante avaliar a quantidade de alimento necessário para o cultivo de qualquer espécie, desde a fase larval até o momento da despesca. Ajustes quinzenais na taxa de arraçoamento, em função das biometrias, contribuirão bastante para tais melhorias (SUSSEL, 2008).

A qualidade do alevino atrelada a idade ou fase de crescimento do peixe relaciona-se ainda a outros parâmetros que interferem no consumo e no desempenho do animal. Machos e fêmeas em maturação de gônadas requerem maiores níveis de nutrientes do que peixes em repouso gonadal (SANTOS, 2013).

\section{Qualidade da água}

A água influencia diretamente no cultivo do tambaqui. Considera-se fundamentais os parâmetros de temperatura da água, $\mathrm{pH}$, quantidade de oxigênio dissolvido, as concentrações de amônia presente no meio, a transparência, os teores de nitrito e nitrato.

A temperatura da água pode influenciar o consumo de forma positiva, visto que está diretamente relacionada à temperatura do animal que influencia na atividade enzimática e metabólica dos peixes. A atividade das enzimas digestivas como amilase, maltase, tripsina e quimotripsina, no intestino e cecos pilóricos, além das proteases no estômago e amilases no estômago e esôfago, é acelerada às temperaturas de 35 a $40{ }^{\circ} \mathrm{C}$ (RODRIGUES, 2014). Este fator faz com que a espécie cultivada nas regiões tropicais apresentem maior desempenho ás cultivadas em regiões mais frias.

O tambaqui suporta valores abaixo de $1 \mathrm{mg} \mathrm{L}^{-1}$ de oxigênio dissolvido na água (GRAEF, 1995) e possui capacidade de expansão do lábio inferior para realizar a captura de oxigênio em condições extremas de falta deste, que lhe permite captar e direcionar a água das camadas mais superficiais, rica em oxigênio, para as brânquias 
(ARAUJO-LIMA, e GOULDING, 1998; BALDISSEROTTO, 2009). Maior crescimento é obtido em águas ácidas, com pH entre 4 e 6 (ARIDE et al 2007), sendo a espécie resistente à ação tóxica da amônia, podendo atingir valores de até $0,46 \mathrm{mg} \mathrm{L}^{-1}$ de amônia não ionizada (ISMIÑO-ORBE et al, 2003).

\section{Manejo nutricional}

No manejo nutricional dentre os fatores que podem afetar o consumo está a palatabilidade da ração, o tamanho do pélete, a relação entre a energia e a proteína bruta da dieta, frequência e taxa de arraçoamento dentre outros.

Machado (2014) avaliando juvenis de tambaqui em diferentes taxas de arraçoamento observaram um aumento linear no ganho de peso e rendimento de carcaça quanto maior a quantidade de ração fornecida (Tabela 2), apesar da menor amplitude do ganho de peso a partir da taxa de alimentação de $6 \%$ do peso corporal.

Tabela 2 - Desempenho e Rendimentos de alevinos de tambaqui em diferentes taxas de alimentação.

\begin{tabular}{|c|c|c|c|c|c|c|c|c|c|}
\hline \multirow[t]{2}{*}{ Variável } & \multicolumn{5}{|c|}{ 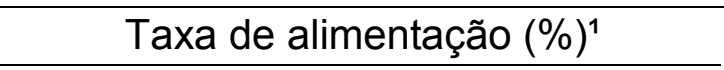 } & \multicolumn{3}{|c|}{ Contraste $^{2}$} & \multirow[t]{2}{*}{$\mathrm{CV}(\%)$} \\
\hline & 2 & 4 & 6 & 8 & 10 & $\mathrm{~L}$ & $Q$ & $\mathrm{C}$ & \\
\hline Peso corporal inicial (g) & 34,3 & 32,2 & 32,6 & 32,2 & 33,9 & - & - & - & - \\
\hline Peso corporal final $(\mathrm{g})^{3}$ & 169,9 & 232,6 & 297,5 & 287,0 & 314,9 & * & ns & ns & 14,37 \\
\hline Ganho médio diário (g) & 2,3 & 3,3 & 4,4 & 4,2 & 4,6 & ns & ns & ns & 17,61 \\
\hline Carcaça (g) & 101,72 & 141,70 & 184,96 & 176,57 & 197,83 & * & ns & ns & 14,24 \\
\hline Órgãos e vísceras (g) & 11,56 & 15,87 & 21,00 & 19,42 & 21,14 & * & ns & ns & 15,23 \\
\hline Cabeça (g) & 43,34 & 57,65 & 71,22 & 67,92 & 74,75 & $*$ & ns & ns & 16,07 \\
\hline $\begin{array}{l}\text { Rendimento de carcaça } \\
(\%)\end{array}$ & 64,77 & 65,85 & 66,80 & 66,9 & 67,27 & * & ns & ns & 1,83 \\
\hline $\begin{array}{l}\text { Conversão alimentar } \\
\text { aparente }\end{array}$ & 0,64 & 0,92 & 1,25 & 1,75 & 2,06 & * & ns & ns & 15,22 \\
\hline $\begin{array}{l}\text { Fornecimento de ração } \\
\% \text { PC }\end{array}$ & 1,32 & 3,32 & 5,65 & 7,83 & 11,30 & & & & \\
\hline
\end{tabular}

Contudo, o autor destaca um aumento na conversão alimentar aparente quanto maiores as taxas de alimentação, sendo necessário mais ração por 
quilograma de carne produzido, assim como destaca a necessidade do produtor realizar a análise econômica do sistema, a fim de verificar a viabilidade financeira do fornecimento de taxas mais elevadas de rações, nesta fase de crescimento, que demanda rações mais proteicas e aumenta o custo de produção.

A frequência alimentar tem gerado dúvida aos produtores e técnicos em piscicultura. Esta pode aumentar o gasto com mão-de-obra à medida que se aumenta a frequência de alimentação. Desta forma, dependendo da fase produtiva em que o animal encontra-se a frequência pode ser reduzida sem implicar em menor desempenho. Souza et al (2014), avaliando o desempenho e rendimentos de alevinos tambaquis de 15 gramas em tanques-rede, alimentados com ração contendo $45 \%$ de PB a $5 \%$ de taxa de arraçoamento, não encontraram diferenças no desempenho entre as taxas de arraçoamento recomendando a frequência de alimentação de duas vezes ao dia para juvenis de tambaqui, principalmente visando minimizar o custo com mão de obra (Tabela 3 ).

As taxas de arraçoamento, dada pela quantidade de ração fornecida em relação ao peso corporal, foi estudada por Chagas et al (2007), os autores observaram que o tambaqui a partir de $200 \mathrm{~g}$ apresentaram menor ganho de peso, porém melhor conversão alimentar aparente (CAA) na taxa de alimentação de $1 \%$ do peso corporal $(320 \mathrm{~g}$ e CAA de 1,98$)$ quando comparado as taxas de 3 e $5 \%$ do PC CAA (490 e 595 g; CAA de 4,8 e 7,0, respectivamente).

Tabela 3 - Variáveis médias de desempenho e glicose dos alevinos de tambaqui submetidos a várias frequências de alimentação por 30 dias

Variáveis

Frequência de alimentação diária

Peso médio inicial $(\mathrm{g})$

\begin{tabular}{ccccc}
2 & 4 & 6 & 8 & CV (\%) \\
\hline 16,0 & 15,9 & 15,4 & 15,7 & 3,95
\end{tabular}

Ganho de peso médio final ( $\mathrm{g}$ )

$41,0 \quad 46,7 \quad 38,8 \quad 42,7 \quad 20,76$

Consumo total de ração aparente (g)

223,3

226,2

$210,2 \quad 201,2$

7,74

Conversão alimentar aparente 1,52

1,26

1,37

2,01

25,35

Taxa de crescimento específico (\%)

$4,2 \quad 4,53$

4,16

4,35

10,70

Glicose plasmática (mg/dL) 97,75 89 82,87

89,25

13,89

Sobrevivência (\%)

$93,75 \quad 100$

100

95 12,98

Fonte: Souza et al (2014)

Estudos sobre as exigências nutricionais de tambaqui em tanques rede ou cultivo ainda são incipientes na Região Norte, onde a taxa de crescimento é mais acelerada em função das condições climáticas. Nestas regiões é também grande a demanda por ingredientes alternativos para possibilitar a redução do custo das 
dietas, visto que o valor do transporte dos grãos até as fábricas aumenta o custo das rações.

As proteínas são moléculas complexas, constituídas de aminoácidos, sendo que 20 deles compõem a maioria das proteínas. Estes são os mais importantes nutrientes para a vida, crescimento e produção dos peixes. Os peixes formam suas gorduras a partir de outras gorduras, de carboidratos ou de proteínas ocorrentes nos alimentos. Ao contrário, as proteínas só podem ser formadas a partir de aminoácidos, obtidos pela quebra de proteínas ingeridas por aqueles animais. Por isto, eles devem consumir estes nutrientes para o suprimento contínuo de aminoácidos (RIBEIRO, 2012). As proteínas compõem os ingredientes mais caros na formulação das rações.

Os animais necessitam de proteínas, aminoácidos, gorduras (lipídios), fibras, vitaminas e minerais que estão presentes na ração em suas dietas. Os tipos e quantidades de cada um desses nutrientes variam, não somente entre as espécies, mas dentro das espécies, com a idade, funções produtivas e condições ambientais.

Os peixes são eficientes em catabolizar o excesso de proteína, com gasto de energia menor que o observado para aves e mamíferos. Segundo Cowey (1980), a excreção de nitrogênio, em peixes teleósteos, é feita sob a forma de amônia, sendo $97 \%$ do total eliminados pelas brânquias, sem gasto de energia, e somente os $3 \%$ restantes eliminados pela urina. Desta forma, os peixes utilizam mais eficientemente a proteína como fonte de energia que outros vertebrados. Nada é mais importante nas criações de peixes em cativeiro do que boa dieta balanceada, combinada com adequado manejo alimentar. Se não houver consumo de alimento suficiente não haverá crescimento e, quase sempre, ocorrerá aumento na mortalidade.

Lima et al. (2016) trabalhando com alevinos de tambaqui com peso inicial 0,35 g fornecendo rações com diferentes teores de proteína bruta (PB, 20 a 40\%) obtiveram efeito quadrático com ponto de máxima na ração contendo $36 \%$ de $P B$, onde os animais ganharam $15,45 \mathrm{~g}$. Os autores obtiveram melhor conversão alimentar a medida que aumentaram o teor de PB da ração com valores de 1,46 e $0,89 \mathrm{~g} \mathrm{~g}^{-1}$, para 20 e $40 \%$ de PB, respectivamente. Isto demonstra que o teor de PB na dieta pode influenciar diretamente no consumo de ração. Resultado semelhante foi encontrado por Machado et al. (dados não publicados) quando avaliaram rações comerciais contendo 32 e $36 \%$ de PB, para alevinos de tambaqui com peso inicial de $1,08 \mathrm{~g}$, os pesquisadores verificaram maior peso final para os alevinos que receberam a ração com $36 \%$ de $\mathrm{PB}(31,97$ versus $40,26 \mathrm{~g})$.

Segundo Porto et al. (2016) ao avaliar níveis crescentes de PB (28, 32, 36 e $40 \%$ de PB) na ração para alevinos com peso inicial de $35 \mathrm{~g}$ até $160 \mathrm{~g}$, verificaram maior ganho de peso para os juvenis recebendo a ração com $28 \%$ de PB em relação a média dos demais tratamentos (2,63 g versus 2,04 g). Contudo, na continuidade do 
mesmo trabalho realizado por estes autores, foi verificado tendência a efeito quadrático (Valor-P $=0,1186$ ) com ponto de máximo para os animais recebendo ração comercial contendo $36 \%$ de $\mathrm{PB}$, onde o peso final foi de $534 \mathrm{~g}$, quando comparado a média dos demais tratamentos, que foi de $489 \mathrm{~g}$. Na literatura não se tem informação sobre as exigências nutricionais de proteína bruta para tambaquis com peso mais elevados que os supracitados.

De acordo com Silveira et al. (2009) os carboidratos representam o grupo de nutrientes mais controversos na alimentação de peixes, uma vez que estes não expressam deficiências e sintomas de carência evidentes. Estes mesmos autores relatam que os peixes, de uma forma geral, não apresentam um requerimento específico de carboidratos na dieta. Porém, algumas espécies exibem uma redução moderada na taxa de crescimento quando alimentadas com dietas livres de carboidratos. Desta forma, o nível de carboidratos na dieta, considerado ótimo, é muito variável, com valores entre 7 e $40 \%$ de acordo com Silveira et al. (2009) e vai depender, principalmente, do hábito alimentar de cada espécie.

O consumo de ração pelos peixes pode ser regulado pela ingestão de energia. Assim, uma dieta deficiente em energia aumentará o consumo de alimentos e, em casos extremos, uma maior utilização da proteína para gerar energia, em detrimento do uso desta para uso em processos anabólicos. Outro extremo seriam as dietas com excesso de energia que podem limitar o consumo de proteínas, vitaminas e minerais aumentando a deposição de gordura corporal, sobretudo a gordura visceral (MORAES et al 2015). A relação energia/proteína das dietas ainda é controvérsia, sendo utilizadas dietas que variam de 6 a $12 \mathrm{Kcal} / \mathrm{g}$ proteína, sendo o mais usual dietas com $10 \mathrm{Kcal} / \mathrm{g}$ proteína.

Os ingredientes energéticos mais comuns na fabricação de rações para peixes são o milho, o sorgo e o trigo. O milho é o alimento energético padrão para diversas espécies animais, sendo a principal fonte energética que compõe as rações para peixes onívoros e herbívoros.

\section{Fotoperíodo}

O fotoperíodo ou tempo de exposição à luminosidade afeta a fisiologia de crescimento e a reprodução do tambaqui (MENDONÇA et al 2012). Os mesmos autores avaliando a influência do fotoperíodo de $6,12,18$ e 25 horas de luminosidade sobre o desempenho de alevinos de tambaquis (Tabela 4), observaram influência positiva do fotoperíodo para o ganho de peso, conversão alimentar, 
comprimento corporal, taxa de crescimento específico, taxa de eficiência proteica e ganho de peso diário. Segundo os autores, o fotoperíodo tem influência significativa sobre características de crescimento e consumo de ração do tambaqui, especialmente acima de 15 horas de luz.

A Região Norte caracteriza-se por períodos mais longos de luz solar e altas temperaturas o que faz com que o tambaqui, espécie nativa e com hábitos de alimentação luz do dia, tenha seu consumo de alimentos estimulado e otimize seu metabolismo.

Tabela 4 - Valor médio para peso, ganho de peso, consumo de alimento e conversão alimentar para tambaqui em diferentes fotoperíodos

Variável

Peso final(g)

Ganho de peso $(g)$

Consumo de alimento $(\mathrm{g})$

Conversão alimentar aparente

Taxa de crescimento específico (\%)

Fonte: Mendonça et al. (2012) - Adaptado
Tratamentos (horas de luz)

\begin{tabular}{c|c|c|c|}
6 & 12 & 18 & 24 \\
\hline 41,71 & 44,31 & 45,65 & 51,73
\end{tabular}

$29,42 \quad 32,05 \quad 33,53 \quad 39,69$

$62,20 \quad 71,77 \quad 72,60 \quad 86,53$

$1,78 \quad 1,78 \quad 1,81 \quad 1,97$

$2,96 \quad 3,22$

Destaca-se assim o potencial de criação da espécie cultivada e beneficiada no Estado de Rondônia além da necessidade em estudos relacionando a espécie a técnicas de avaliação de rendimentos do pescado (REIS NETO et al 2012).

\section{Considerações Finais}

O manejo nutricional e alimentar correto irá garantir o crescimento do tambaqui, em condições de saúde adequadas, permitindo que os peixes resistam às condições impostas pelo sistema de criação, dificultando o aparecimento de doenças. Além disto, os fornecimentos adequados de rações aos peixes, tanto pela escolha apropriada da ração, quanto pela estratégia de alimentação, contribuem para redução no desperdício de alimento, diminuindo a poluição ambiental e o custo de produção. 
O conhecimento de níveis de proteína que sejam adequados para atender as exigências de tambaqui criados em sistemas mais intensivos torna-se necessário, visando aumentar o desempenho produtivo e econômico dos mesmos e ainda, reduzir os níveis de amônia na água.

\section{Referências}

ALMEIDA, A. R. de. Indicadores econômicos da nutrição de alevinos de tambaqui em tanques-rede: níveis de proteína e densidades de estocagem. In: Seminário Programa de Iniciação Científica. Anais... PIBIC:UNIR, 2014.

ARAUJO-LIMA,C.R.M.; GOULDING,M. So fruitful fish:ecology, conservation, and aquaculture of the Amazon's tambaqui. New York:Columbia University Press, 1997. $157 p$.

ARIDE, P.H.R.; ROUBACH, R.; VAL, A.L. Tolerance response of tambaqui Colossoma macropoum (Cuvier) to water pH. Aquaculture Research, 38: 588-594. 2007.

BALDISSEROTTO, B. 2009 Respiração e circulação. In: BALDISSEROTTO, B. Fisiologia de peixes aplicada à piscicultura. $2^{\mathrm{a}}$ ed. Santa Maria: Editora UFSM. p.5375.

CARVALHO, C.F. Desempenho produtivo e Rendimentos de carcaça, cortes e coprodutos de tambaqui cultivados em tanque-rede, sob diferentes taxas de alimentação. Trabalho de Conclusão de Curso (Graduação em Engenharia de Pesca e Aquicultura) - Universidade Federal de Rondônia. 62p. 2015.

CHAGAS, E.C., GOMES, L.C., MARTINS JR. H., ROUBACH. Produtividade de tambaqui criado em tanque-rede com diferentes taxas de alimentação. Ciência Rural, v.37, n.4, 2007.

CHELLAPA, S.; CHELLAPA, N.T.; BARBOSA, W.T.; HUNTIGORD, F.A.; BEVERIDGE, M.C.M. Growth and production of the Amazonian tambaqui in fixed cages under different feeding regimes. Aquaculture International, v.3, p.11-21, 1995.

COMPANHIA DE DESENVOLVIMENTO DOS VALES SÃO FRANCISCO E PARANAÍBA - CODEVASP. Manual de criação de peixes em tanques-rede. 2. ed. Brasília: Codevasf, 2013. 68 p.

COWEY, C.B. Protein metabolism in fish. In: BUTTERY, P.J., LINDSAY, D.B. Protein deposition in animals. London: Butterworths, 1980. p.271-288. 
FURUYA,W. M.; PEZZATO, L. E.; PEZZATO, A. C.; BARROS, M M.; MIRANDA E. C. de. Coeficientes de Digestibilidade e Valores de Aminoácidos Digestíveis de Alguns Ingredientes para Tilápia do Nilo (Oreochromis niloticus). Revista Brasileira Zootecnia, v.30 n.4 2001.

GOMES, L.C.; BALDISSEROTTO, B.; SENHORINI, J.A. Effect of stocking density on water quality, survival, and growth of larvae of matrinxã, Brycon cephalus (Characidae), in ponds. Aquaculture, v.183, p.73-81, 2000.

GOMES, L.C.; CHAGAS, CHAGAS, E.C.; MARTINS-JUNIOR, H.; ROUBACH, R; ONO, E.A. LOURENÇO, J.N. Cage culture of tambaqui (Colossoma macropomum) in a central Amazon floodplain lake. Aquaculture, Amsterdam, v. 253, p. 374-384, 2006.

GRAEF, E. W. 1995. As espécies de peixes com potencial para criação no Amazonas, In: Val, L. A. (Eds). Criando peixes na Amazônia. Instituto Nacional de Pesquisas da Amazônia, Manaus, Amazonas. p. 29-43.

ISMIÑO-ORBE, R.A., ARAUJO-LIMA, C.A.R.M., GOMES, L.C. Excreção de amônia por tambaqui (Colossoma macropomum) de acordo com variações na temperatura da água e massa do peixe. Pesquisa agropecuária brasileira, v. 38, n. 10, p. 12431247 , out. 2003.

IZEL, A.C.U.; MELO, L.A.S. Criação de tambaqui (Colossoma macropomum) em tanques escavados no estado do Amazonas. Manaus: Embrapa Amazônia Ocidental. 19p. 2004

LIMA, C. S.; BOMFIM, M.A.B.; SIQUEIRA, J.C.; RIBEIRO, F.B.; LANNA, E.A.T. Crude protein levels in the diets of tambaqui, Colossoma macropomum (cuvier, 1818), fingerlings. Revista Caatinga, v.29, n.1, p.183-190, 2016.

MACHADO J.J. Desempenho produtivo e econômico de juvenis de Tambaqui (Colossoma macropomum, 1816) em tanque-rede, sob diferentes taxas de fornecimento de ração. Trabalho de Conclusão de Curso (Graduação em Engenharia de Pesca e Aquicultura) - Universidade Federal de Rondônia. 35 p. 2014.

MELO, L.A.S.; IZEL, A.C.U.; RODRIGUES, F.M. Criação de tambaqui (Colossoma macropomum) em viveiros de argila/barragens no Estado do Amazonas. Embrapa Amazônia Ocidental, 2001. 25p.

MENDONÇA, P.P, VIDAL JUNIOR, M.V.; POLESE, M.F.; DOS SANTOS, M.V.B.; REZENDE, F.P. ANDRADE, D.R. Morphometrical development of tambaqui (Colossoma macropomum, Cuvier, 1818) under different photoperiods. Revista Brasileira Zootecnia, v.41, n.6, p.1337-1341, 2012. 
PEDRAZZANI, A. S.; MOLENTO C. F. M.; CARNERO P. C. F.; CASTILHO M. F. Sensciência e bem-estar de peixes: uma visão de futuro do mercado consumidor. Panorama da Aquicultura, Rio de Janeiro, v.17, n.102, jul./ ago. 2007.

PINHEIRO, L.M., COTA, T; ROCHA, C. T; PORTO, M. O; BELETE, N.A.S; CAVALI, J. Caraterização dos processos e produtos do pescado nas indústrias frigorificas do Estado de Rondônia. Anais... In: VI SIMPÓSIO DE CONTROLE DE QUALIDADE DO PESCADO. Santos: SIMCOPE. 2014.

PORTO, M. S. A. Indicadores de estresse em peixes da Amazônia: sensibilidade em face do tipo de estressor. 2005. Dissertação (Mestrado em Ciências Biológicas) Universidade Federal do Amazonas, Manaus, 2005.

PORTO, M.O.; ALMEIDA, A.R.CAVALI, J. LUXINGER, A.O.; CARAVALHO, C.F.; MORAES, C.R.; ROCHA, R.B.; SANTOS, V.F.; LIMA, M.; FERREIRA, E. Desempenho produtivo de tambaqui sob, diferentes níveis de proteína em rações comerciais na fase de crescimento. Anais... In: World Aquaculture Society - LAQUA p.223, 2016.

REIS NETO, R.V., FREITAS, R.T.F., SERAFINI, M.A., COSTA, A.C., FREATO, T.A., ROSA, P.V., ALLAMAN, I.B. Interrelationships between morphometric variables and rounded fish body yields evaluated by path analysis. Revista Brasileira de Zootecnia, v.41, n.7, p.1576-1582, 2012.

RIBEIRO P. A. P.; MELO D. C.; COSTA L. S.; TEIXEIRA E. A.; Manejo nutricional e alimentar de peixes de água doce. Belo Horizonte, Minas Gerais, 2012.

RODRIGUES, A.P.O. Nutrição e alimentação do tambaqui (Colossoma macropomum). Boletim do Instituto da Pesca, São Paulo, n.40, v.1, p.135-145, 2014.

SANTOS. F.W.V. Nutrição De Peixes De Água Doce: Definições, Perspectivas E Avanços Científicos. Secretaria Especial de Aquicultura e Pesca. In: SEAP-Secretaria Especial de Aqüicultura e Pesca. 36p. 2013.

SOUZA, R.C., CAMPECHE, R.M.L., CAMPOS, D.F.B., FIGUEIREDO, R.A.C.R., MELO, J.F.B. Frequência de alimentação para juvenis de tambaqui. Arq. Bras. Med. Vet. Zootec., v.66, n.3, p.927-932, 2014.

SUSSEL, F. R. Alimentação Na Criação De Peixes Em Tanques-Rede. Assis- SP, 2008.

\section{Agradecimentos}

A NUTRIZON Alimentos, Piscicultura do Sr Edilson e CNPq pelo apoio a pesquisa 


\title{
Sanidade de Peixes em Cultivo
}

\author{
Bruna Rafaela Caetano Nunes Pazdiora ${ }^{19}$, Henrique Magalhães de Sales Neto ${ }^{20}$
}

\section{Introdução}

A sanidade é um dos aspectos mais relevantes para a produção comercial de animais aquáticos. Com o aumento significativo da aquicultura no Brasil tem aumentado a importância dos estudos de parasitas e outros patógenos de organismos aquáticos, especialmente naqueles que hospeda espécies com potencial para o cultivo (EIRAS et al, 2010).

Devido à intensificação da produção nas pisciculturas, podem ocorrer surtos epizoóticos (mortalidade) causados pelo surgimento de doenças parasitárias e bacterianas e/ou pelo estresse de manejo e transporte que os peixes sofrem rotineiramente, somados à alta densidade de estocagem de peixes utilizada. Esses são fatores limitantes à produção e produtividade, resultando em perdas econômicas e/ou gastos com tratamentos antiparasitários. (TAVARES-DIAS, MONTAGNER, 2016; SANTOS et al, 2013)

Estes patógenos podem ser bactérias, protozoários, e fungos e estão presentes no meio natural, mas quando os peixes são submetidos às condições estressantes o sistema imune é afetado, resultando em queda da resistência, permitindo assim a proliferação do parasita. Não obstante existem ainda os metazoários, parasitas monogeneas, que são responsáveis por grandes mortandades em pisciculturas em condições ambientais não favoráveis sendo também motivos de preocupação (EIRAS et al, 2010; PAVANELLI et al, 2013).

As perdas causadas por parasitas e outros patógenos representam um fator determinante para o sucesso da piscicultura, pois além de disseminar agentes patogênicos para o ambiente, representam riscos à saúde pública. $O$ conhecimento da distribuição parasitária, bem como, da complexa relação entre fatores ambientais,

19 Zootecnista, Dra em Ciências Agrárias. Departamento de Zootecnia da Universidade Federal de Rondônia.bruna.nunes@unir.br

20 Mestrando em Produção de Organismos Aquáticos. Programa de Pós-graduação em Ciências Veterinárias, UFLA 
hospedeiros e parasitos são importantes para que se possa intervir no sistema, com técnicas profiláticas adequadas, criando programas preventivos de controle destas enfermidades.

Principais doenças em peixes de cultivo - Caso Tambaqui (Colossoma macropomum) e Pirarucu (Arapaima gigas)

\section{Doenças causadas por protozoários}

Vários protozoários são responsáveis por causar doenças em peixes de criação, portanto estão entre os principais grupos de parasitos responsáveis por surtos epizoóticos em fazendas de criação. O filo Protozoa reúne diversos organismos de vida livre em todo o mundo, evolutivamente distintos, que atuam principalmente como ectoparasitas. Estes agentes são responsáveis pela etiologia de várias doenças na aquicultura global, além de ocasionar a fragilização do hospedeiro, tornando-o mais susceptível às infecções secundárias, especialmente pelas bacterioses (KUBTIZA, KUBTIZA, 1999; KUBTIZA et al, 2000,).

Ichthyophthirius multifilis: São ectoparasitos ciliados localizados na pele e nas brânquias de peixes de água doce. É o agente etiológico da ictiofitiríase também conhecida como "doença dos pontos brancos", devido aos sinais clínicos característicos (PÁDUA et al, 2012). Esta espécie é considerada a responsável por grandes prejuízos na piscicultura mundial. Apresenta um ciclo direto que pode se completar em poucos dias onde o parasito adulto (Trofonte) que está presente no tecido branquial ou na pele dos hospedeiros; atingindo a maturidade, sai do hospedeiro e fica no substrato dos tanques de cultivo, denominando-se Teronte que são as formas infectantes (EWING, KOCAN, 1988).

Dentre os sinais clínicos estão, pontos brancos na superfície do corpo, nadadeiras e brânquias, com o agravamento da condição clínica dos peixes, é possível observar peixes apáticos, com natação errática e sem vigor, além de anorexia, mudança da coloração da pele, hemorragias e posterior invasão bacteriana e fúngica, com aspecto de algodão. Estudos patológicos mostram a laceração das células epidérmicas, e a necrose do tecido devido ao acúmulo de muco. No tecido branquial, são responsáveis por considerável perda funcional do órgão (PAVANELLI et al, 2008, VENTURA, PAPERNA, 1985). 
O diagnóstico da ictiofitiríase é realizado de forma simples e rápida, a partir do raspado, tanto da pele quanto das brânquias, e pesquisa pelo parasito em microscópio óptico. A partir desta análise é possível observar o protozoário com o aumento de 40 vezes (objetiva de 4x), exibindo movimento rotativo, além da coloração escurecida do corpo e um macronúcleo mais claro, em forma de ferradura, apenas presente nos organismos adultos (PÁDUA et al, 2012). A maneira mais adequada para se evitar a ictiofitiríase é levar em conta a boa qualidade da água, e evitar o estresse, principalmente o motivado pelas oscilações térmicas bruscas. Recomendam- se ainda banhos profiláticos e quarentena (LUQUE, 2004).

Trichodina spp.: São ectoparasitas ciliados de forma circular, encontrados com freqüência na superfície e nas brânquias dos peixes, possui um disco adesivo com uma série de dentículos (figura 1). Possui um ciclo de vida direto, realizando a fissão binária como principal forma de replicação sobre o hospedeiro. Após o processo de divisão, as células filhas reabsorvem os dentículos velhos e formam novos dentículos (MADSEN et al, 2000, HECKMANN, 1996). Com este processo, conseguem obter altos níveis da intensidade de parasitismo em um curto espaço de tempo, sob influência da disponibilidade de alimento e temperatura da água.

Figura 1 -Trichodina, objetiva de 100, seta (dentículos). Arquivo pessoal dos autores.

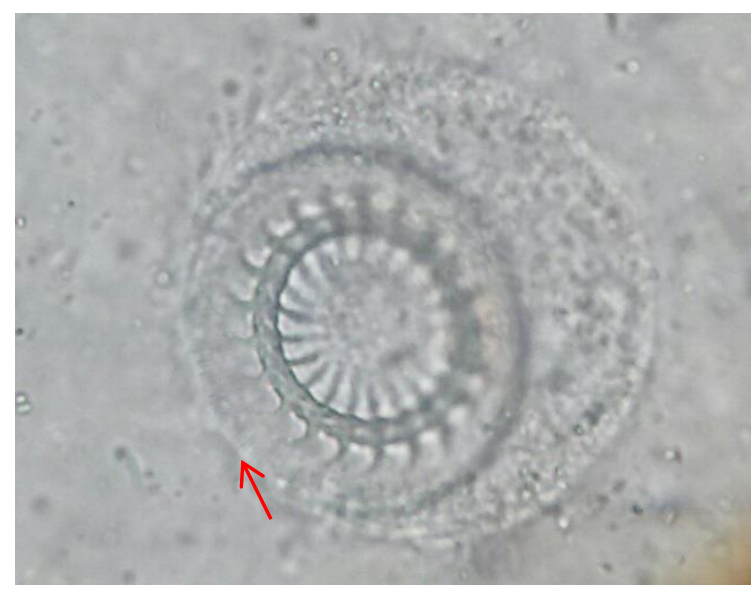

Estes parasitos podem estar normalmente nos tanques de cultivo, mas proliferam principalmente em águas com excesso de material em decomposição. Provocam produção excessiva de muco e hemorragias em forma de petéquias, também hiperplasia e necrose da epiderme, sendo portas abertas para infecções secundárias. A patogenia fica apenas evidente nos casos de grande intensidade parasitária (ZANOLO, YAMAMURA, 2006; EIRAS et al, 2010). O diagnóstico é através do exame microscópico de raspagens da superfície e branquias (Figura 2).

O tratamento pode ser feito com banhos profiláticos e quarentena, cuja duração pode variar de acordo com os diferentes hospedeiros (KUBTIZA, KUBTIZA, 2004). 
Figura 2 - Diagnóstico de tricodinídeos em raspado de pele de Pirarucu (Arapaima gigas) severamente parasitado. Objetiva de 4. Arquivo pessoal.

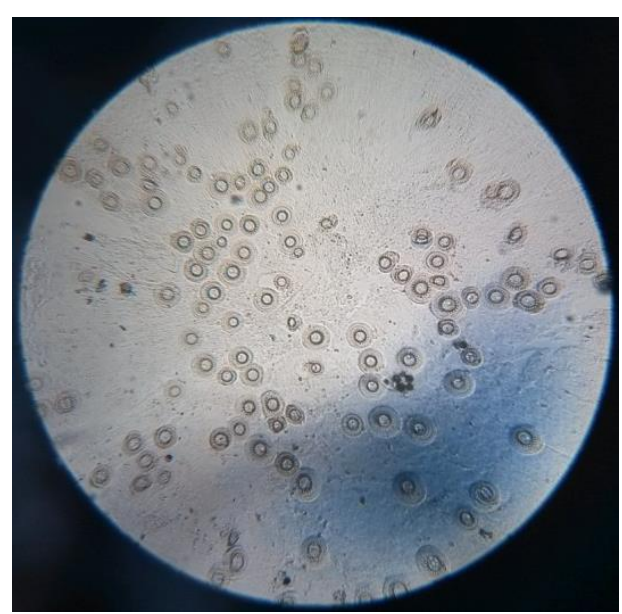

\section{Doenças causadas por helmintos}

As helmintíases compreendem doenças parasitárias causadas por diferentes tipos de vermes que infectam hospedeiros invertebrados e vertebrados em todo o mundo. Na piscicultura brasileira, as doenças causadas por vermes estão entre as principais causas de mortalidade, principalmente relacionadas às verminoses de pele e brânquia, ocasionada pelo grupo Monogenea (TAKEMOTO et al, 2004). No entanto, vermes endoparasitos como os nematódeos, cestódeos e acantocéfalos são comumente diagnosticados em peixes de criação, principalmente no cultivo de espécies nativas (PAVANELLI et al, 2013). Estes endoparasitos geralmente causam um impacto silencioso sobre os aspectos produtivos e desempenho do plantel, uma vez que os piscicultores dificilmente detectam sua presença, pela carência de um programa de monitoramento sanitário para o diagnóstico precoce da doença. Dessa forma, o diagnóstico geralmente é realizado de forma tardia, quando o problema encontra-se completamente disseminado e com a contaminação de todo o sistema de criação.

Monogenea: São helmintos ectoparasitos, mais prevalentes em peixes de água doce no Brasil. São caracterizados pela presença de estruturas de fixação esclerotizadas (haptor) (figura 3) e pelo ciclo biológico direto. A maioria das espécies é ovípara, entretanto, os Gyrodactilídeos compõem um grupo integrado por espécies vivíparas (UEDA et al, 2013; EIRAS et al, 2010). 
Figura 3 - Exemplar de Dactylogyridae, destaque para o haptor (ganchos). Arquivo pessoal.

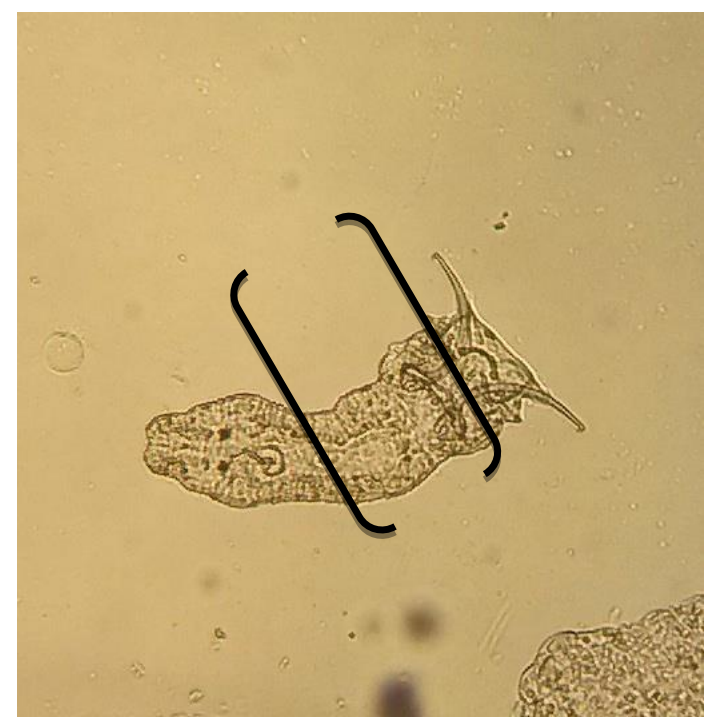

A localização preferencial nos peixes é nas brânquias, narinas, olhos e na superfície corporal. Em infecções intensas eles podem provocar lesões nos tecidos branquiais, vitais ao hospedeiro, alterando seu comportamento e podendo levá-los a morte (PAVANELLI et al, 2008). Também em infecções menos intensas as pequenas lesões são portas abertas para infecções secundárias.

Os monogenéticos parasitos de peixes de água doce pertencem na sua grande maioria a duas famílias: Dactylogyridae (Figura 3) e Gyrodactylidae (Figura 4). No caso dos Gyrodactilídeos, o viviparismo é revelado com a presença de um outro indivíduo semelhante, e assim sucessivamente até atingir quatro gerações no mesmo animal (EIRAS et al, 2010).

O diagnóstico pode ser efetuado através da visualização direta através microscopia de raspado coletado das brânquias e muco. Também neste caso a profilaxia é fundamental, com banhos (formalina 1:4000, cloreto de sódio) e quarentenas (KUBTIZA, KUBTIZA, 2004).

Nematoda: Apesar de ser o maior grupo de parasitos de peixes, os nematóides são considerados, pouco prevalentes em peixes de cultivo, devido apresentarem ciclo de vida indireto, com a participação de diversos hospedeiros intermediários, entre eles, copépodes planctônicos, aves silvestres, moluscos entre outros. São fáceis de serem reconhecidos, devido ao formato alongado com extremidades afiladas. São dióicos e exibem dimorfismo sexual (MARTINS et al, 2004, TAKEMOTO et al, 2004 ).

No Brasil, existem relatos sobre a presença de espécies de Philometra em peixes de água doces, estas são normalmente encontradas encistadas na pele, 
nadadeiras, ovário e cavidade corporal provocando peritonite. Nematóides da família Atractidae (Rondonia rondoni) têm mostrado grande intensidade de parasitismo, mas aparentemente não mostram alterações histopatológicas nos tecidos dos Pacus (Piaractus mesopotamicus e Myleus micans) e do armado (Pterodoras granulosus), embora exista a possibilidade de provocar obstrução intestinal (DIAS et al, 2004; TAVARES-DIAS, 2001).

O diagnóstico pode ser efetuado através necropsia do hospedeiro, realizando uma visualização direta do parasito coletado no sistema digestivo (estômago e intestino) (PAVANELLI et al, 2013). Também neste caso, a profilaxia é fundamental, evitando aves e outros animais próximos ao local de cultivo, impedindo assim que fechem o ciclo.

Acantocéfalos: são geralmente vermes cilíndricos, longos e que não tem tubo digestivo. São dotados de trompas de fixação (probóscide), provida de ganchos, porém não se tem observado como agente patogênico grave de peixes, podem causar lesões locais na mucosa intestinal, porém sem retardo no crescimento (KABATA, 1985, MELO et al, 2013a).

O seu ciclo de vida é complexo e envolve em muitos casos mais do que um hospedeiro. De uma forma geral, o embrião de acantocéfalo é expelido do organismo hospedeiro através das fezes, em seguida, é necessário que seja comido por um hospedeiro intermédio, em geral crustáceos, em vez de digerido, o embrião penetra a parede intestinal do crustáceo e aloja-se na cavidade abdominal, onde enquista e se transforma em cistacanto. Em determinado momento, o hospedeiro intermédio é ingerido pelo hospedeiro final, que pode ser um mamífero, aves ou peixes. A digestão do crustáceo provoca a libertação do acantocéfalo nos intestinos do hospedeiro final. Para garantir a fixação, o cistocanto extrai a probóscide e fixa-se aos intestinos, desenvolvendo-se então para a fase adulta (THATCHER, 1980, KRITSKY, THATCHER, 1984, EIRAS et al, 1994).

O diagnóstico pode ser efetuado através de necropsia do hospedeiro, realizando uma visualização direta do parasito coletado no sistema digestivo (estômago e intestino) (PAVANELLI et al, 2008). Também neste caso a profilaxia é fundamental.

\section{Doenças causadas por Crustáceos}

Os crustáceos parasitas são organismos altamente modificados cujos apêndices orais e natatórios tem se transformado em potentes órgãos de fixação ao hospedeiro, com as consequentes repercussões patogênicas. 
Perulernaea gamitanae: É um crustáceo de ordem Copepoda, que possui especificidade pelo seu hospedeiro, parasitando exclusivamente tambaqui e seus hibridos. De modo geral, apresentam duas fases distintas de crescimento, náuplio e copepodito, antes de atingirem o estágio adulto. A fase naupliar, referente à fase de vida livre, é de seis estágios e a de copepodito, de cinco estágios, sendo que a diferenciação sexual inicia-se apenas a partir do terceiro estágio. Os machos são de vida livre natantes, enquanto apenas as fêmeas são parasitas (BENETTON, MALTA, 1999; THATCHER, 2006; EIRAS et al, 2010; TAVARES DIAS, 2011). Esse lernaeídeo possui a característica de parasitar as fossas nasais, a cavidade bucal, a parede do esôfago e as paredes internas do opérculo do tambaqui (figura 4).

Figura 4 - Exemplar de Perulernaea, parasitando tambaqui (cavidade bucal e narina). Arquivo pessoal.

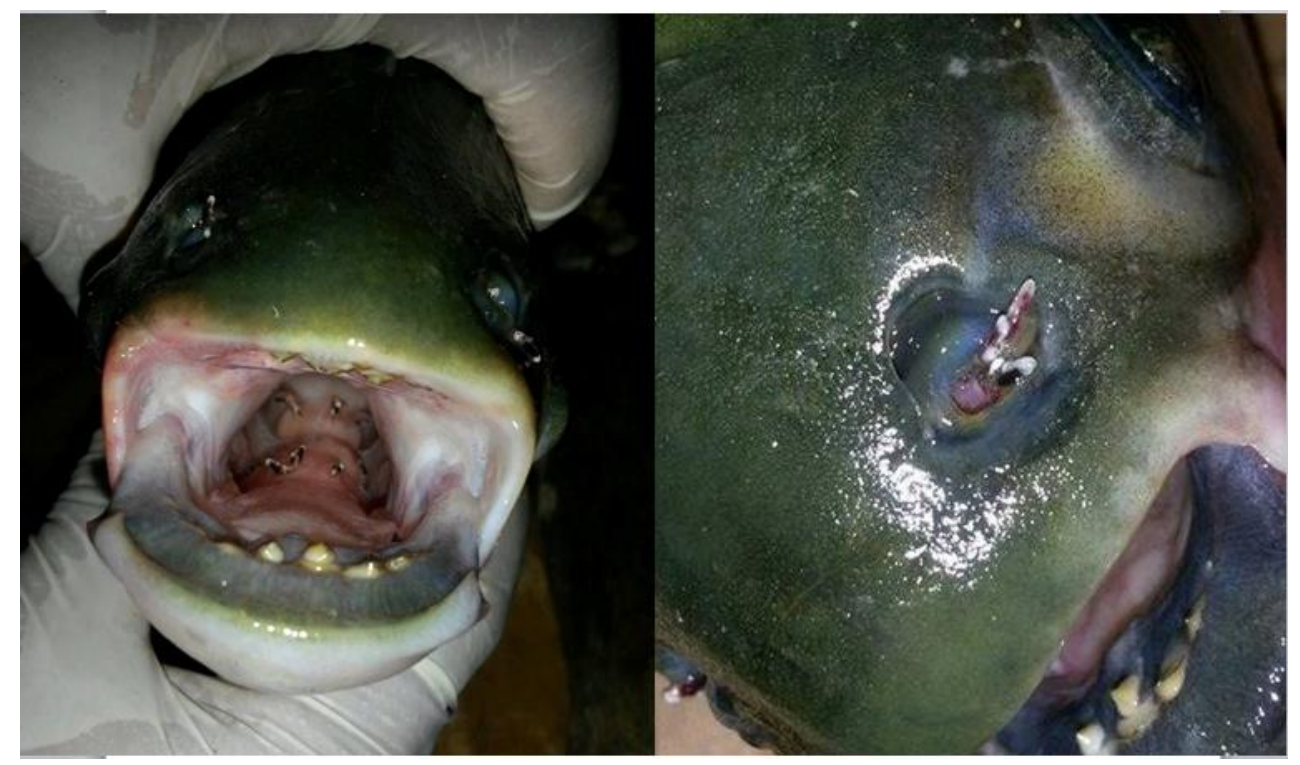

Perulernaea gamitanae é um parasito que pode medir $1,50 \mathrm{~cm}$ de comprimento e infestar cultivos intensivos de tambaqui causando mortalidade. Já foram encontrados mais de 80 parasitos sugando o sangue de um juvenil de tambaqui (FISCHER et al, 2003; TAVARES DIAS, 2011).

A principal profilaxia consiste em não introduzir espécimes parasitados nas pisciculturas. Deve-se tomar atenção para que a água a ser introduzida não contenha formas larvais dos parasitos e a água de transporte dos peixes deve ser descartada (PAVANELLI, et al, 2008). Podem ser aplicados banhos profiláticos e quarentena a cada lote de peixes adquirido. 


\section{Bases para a profilaxia e o controle}

No Brasil, são poucos os estudos realizados para testar a eficácia e os efeitos secundários de fármacos utilizados para combater parasitoses em peixes, principalmente nas criações intensivas. Sem a comprovação científica de sua eficácia, não é possível prever a extensão do prejuízo e em muitos casos, parece ser melhor sacrificar o plantel, drenar e desinfetar o tanque e, a seguir, recomeçar a criação (PÁDUA et al, 2014).

Portanto, o manejo adequado da piscicultura é, sem dúvida, a medida mais importante a ser tomada para evitar que os peixes sejam acometidos pelos mais variados parasitos. Todos os peixes no ambiente natural apresentam uma fauna parasitária característica, muitas vezes sem manifestação patogênica (EIRAS et al, 2006). Entretanto, em condições de cultivo, devido ao aumento da densidade populacional e demais fatores associados, tais organismos (parasitos) podem tornarse patogênicos.

Sendo assim, é de fundamental importância o controle rígido dos fatores físico-químicos (nível do oxigênio, temperatura, $\mathrm{pH}$ e demais) que garantem a qualidade da água, além do adequado fluxo de água nos tanques e do controle da densidade populacional (KUBITIZA, 2012). O transporte adequado dos peixes também é um fator significativo, pois o estresse e as lesões podem facilitar diversas infecções, além dos cuidados requeridos com a água usada no transporte, que pode servir como um veículo de transmissão de parasitos.

Quando os organismos aquáticos se encontram intensamente parasitados ou com lesões profundas, dificilmente recuperam sua normalidade com tratamentos. Portanto, é fundamental o eficiente de manejo sanitário através do uso de diversas medidas profiláticas. Dois procedimentos (preventivos e curativos) devem ser adotados, quanto a: qualidade e procedência dos animais; ambiente de cultivo e qualidade de água; qualidade, conservação e freqüência de alimento; manejo dos animais e equipamentos acessórios ao cultivo e monitoramento da saúde dos animais. Como por exemplo, a desinfecção feita nos equipamentos, utensílios e nos tanques; os banhos profiláticos a serem realizados nos alevinos e nos adultos (PAVANELLI, et al, 2008; TAVARES-DIAS, 2009).

\section{Conclusão}

O conhecimento das principais doenças parasitárias é uma importante ferramenta para a criação de espécies de peixes. Sabendo-se quais as espécies de 
parasitas mais comuns, pode-se, através de medidas de manejo, evitar a proliferação de doenças. Tendo-se em vista que grande parte dos parasitas são comensais, ou seja, são normalmente encontrados nos peixes e no ambiente de cultivo, e só desencadeiam uma doença quando há um desequilíbrio na relação parasita, hospedeiro e ambiente.

\section{Referências}

BENETTON, M.L.F.N.; MALTA, J.C.O. Morfologia dos estágios de náuplios e copepodito I de Perulernaea gamitanae Thatcher \& Paredes, 1985 (Crustacea: Cyclopoida: Lernaeidae), parasita do tambaqui Colossoma macropomum (Cuvier, 1818), (Osteichthyes: Characidae), cultivado em laboratório. Acta Amazonica, v.29, p.97-121, 1999.

DIAS, M.K.R., NEVES, L.R., MARINHO, R.D.G. B., PINHEIRO, D. A., TAVARESDIAS, M. (2015). Parasitism in tambatinga (Colossoma macropomum x Piaractus brachypomus, Characidae) farmed in the Amazon, Brazil. Acta Amazonica, v.45, n.2, p.231-238.

DIAS, P.G.; FURUYA, W.M.; PAVANELLI, G.C.; MACHADO, M.H.; TAKEMOTO, R.M. Carga parasitária de rondoni Travassos, 1920 (Nematoda, Atractidae) e fator de condição do armado, Pterodoras granulosus Valenciennes, 1833, (Pisces, Doradidae). Acta scientiarum: Biological Sciences, v.26, n.2, p.151-156, 2004

EIRAS, J.C., TAKEMOTO, R.M., PAVANELLI, G.C., ADRIANO, E.A. (2010). Diversidade dos parasitas de peixes de água doce do Brasil. Maringá: Clichetec, 2380-2389.

EIRAS, J.C. Elementos de Ictioparasitologia. Porto: Fundação Eng. António de Almeida, 1994. 339 p.

ESTADO, P.E.T.R.N. Ectoparasitos em híbrido tambatinga provenientes de piscicultura em tanque-rede no estado do Amapá (Brasil). Bol. Inst. Pesca, São Paulo, v.41, n.2, p.409-417. 2015.

EWING, M.S.; K.M. KOCAN. Ichthyophthirius multifilis (Ciliophora): population studies suggest reproduction in host epithelium. Journal of Protozoology, v. 35, p. 549-552, 1988.

FISCHER, C.; MALTA, J.C.O.; VARELLA, A.M.B. A fauna de parasitas do tambaqui, Colossoma macropomum (Cuvier, 1818) (Characiformes: Characidae) do médio Rio 
Solimões, estado do Amazonas (AM) e do baixo Rio Amazonas, estado do Pará (PA), e seu potencial como indicadores biológicos. Acta Amazonica, v.33, p. 651-662, 2003.

HECKMANN, R. Protozoan Parasites of Fish, Part II. Aquaculture Magazine, p. 56$59,1996$.

KUBTIZA, F.; KUBTIZA, L.M.M. Principais parasitoses e doenças dos peixes cultivados. $4^{\mathrm{a}}$. ed. Jundiaí: F. Kubitza, 2004. 118 p.

KABATA, ZBIGNIEW. Parasites and diseases of fish cultured in the tropics. Taylor \& Francis Ltd., 1985.

KUBITZA, L. M.M., 2000, Principais parasitoses e doenças em tilápias. Panorama da Aqüicultura, v.10, n.60, p. 39 - 53.

KUBITZA, F, KUBITZA, L. M. M., 1999, Principais Parasitoses e Doenças dos Peixes Cultivados. $3^{\text {a }}$ Edição, Jundiaí, São Paulo, 96p.

KRITSKY, D.C., THATCHER, V.E. (1984). Neotropical monogenea. 6. Five new species of Diplectanum (Diplectanidae) from freshwater teleosts, Plagioscion spp.(Sciaenidae), in Brazil. Proceedings of the Biological Society of Washington (USA).

KUBITZA, F.; CAMPOS, J.L.; ONO, E.; ISTCHUK, P.I. Panorama da Piscicultura no Brasil: estatísticas, espécies, polos de produção e fatores limitantes a expansão da atividade. Panorama da Aquicultura, v. 22, p. 14-25, 2012.

LUQUE, J.L. Biologia, epidemiologia e controle de parasitos de peixes. Revista Brasileira de Parasitologia Veterinária, v.13, p.161-165, 2004. Suplemento.

MARTINS, M.L., TAVARES-DIAS, M., FUJIMOTO, R.Y., ONAKA, E. M., \& NOMURA, D. T. (2004). Haematological alterations of Leporinus macrocephalus (Osteichtyes: Anostomidae) naturally infected by Goezia leporini (Nematoda: Anisakidae) in fish pond. Arquivo Brasileiro de Medicina Veterinária e Zootecnia, 56(5), 640-646.

MADSEN, H.C.K.; BUCHMANN, K.; MELLERGAARD, S. Trichodina sp. (Ciliophora: Peritrichida) in eel Anguilla anguilla in recirculation systems in Denmark: host-parasite relations. Diseases of Aquatic Organisms, v. 42, n. 1. p. 149-152, 2000.

MELO, F. T. V.; COSTA, P. A. F. B.; GIESE, E. G.; GARDNER, S. L.; SANTOS, J. N. A description of Neoechinorhynchus (Neoechinorhynchus) veropesoi $n$. sp. (Acanthocephala: Neoechinorhynchidae) from the intestine of the silver croaker fish Plagioscion squamosissimus (Heckel, 1840) (Osteichthyes: Sciaenidae) off the east coast of Brazil. Journal of Helminthology, Londres, v.1, p. 1-8. 2013a. 
PÁDUA. S.B; FILHO. R. N. Doenças em peixes de criação: Bases para o diagnóstico. Aquivet. 39p. 2014.

PÁdUA, S.B.; MENEZES FILHO, R. N. ; BELO, M. A. A. ; NAGATA, M. M. . Nutritional additive increases the survival rate and decreases parasitism in tilapia during the masculinization. Aqua Culture Asia Pacific , v. 10, p. 24-27, 2014.

PÁDUA, S.B.; MENEZES FILHO, R. N.; DIAS NETO, J. ; JERÔNIMO, G.T. ; ISHIKAWA, M.M ; Martins, Maurício Laterça . Ictiofitiríase: conhecendo a doença para elaborar estratégias de controle. Panorama da Aquicultura, Rio de Janeiro, $p$. 22-31, 21 jul. 2012.

PAVANELLI, G.C.; EIRAS, J.C.; TAKEMOTO, R M. Doenças de peixes: profilaxia, diagnóstico e tratamento. 3. ed. Maringá: Universidade Estadual de Maringá, 2008. $305 \mathrm{p}$.

PAVANELLI, G.C.; TAKEMOTO, R. M.; EIRAS, J.C. (Org.). 2013. Parasitologia de peixes de água doce do Brasil. Maringá: Eduem. 85-114p. 


\section{Qualidade da água na piscicultura}

Fabiano Moreira Figueiredo 21, Rafaela Lemes da Costa ${ }^{22}$, Satia da Costa Bomfim ${ }^{23}$, Juliana Ferraz Huback Rodrigues ${ }^{24}$, Fernanda Bay-Hurtado 25

\section{Introdução}

O crescimento demográfico na entrada do terceiro milênio alcançou a cifra de 6 bilhões de pessoas que necessitam de alimento diário, para suprir esta necessidade, o homem terá de abrir novas frentes agrícolas, porém, poucos países ainda têm novas fronteiras agrícolas para serem desbravadas, nesta corrida, novas alternativas tendo como suporte a água estão sendo propostas, como a hidroponia e aquicultura. Em países como China e Indonésia, a aquicultura progressivamente se torna um dos principias meios de produção de proteína animal (LENZI, 2009).

A aquicultura, ou cultivo de organismos aquáticos, na qual está inserida a piscicultura, é o segmento da produção animal que mais cresce no cenário mundial atual, tendo superado as taxas de crescimento da bovinocultura, da avicultura e da suinocultura (ONO; KUBITZA, 2003). Sua expansão contribui para melhorar a dieta de muitas pessoas, especialmente em áreas rurais pobres, onde a presença de nutrientes essenciais na alimentação são muitas vezes escassos (FAO, 2014).

Conforme dados da FAO (2014) a produção mundial de pescado continua crescendo em um ritmo mais rápido que a população mundial, e aquicultura continua sendo um dos setores de produção de alimentos de maior crescimento. Em 2012 a aquicultura estabeleceu alta recorde de produção e atualmente fornece quase metade do peixe para o consumo humano, projetando que o aumento seja de $62 \%$ em 2030, devido à estabilização do desempenho da pesca de captura selvagem, e

21 Engenheiro de Pesca.

22 Engenheira de Pesca.

23 Bolsista UNIR/CNPq. Acadêmica de Engenharia de Pesca

24 Zootecnista. Programa de Pós-doutorado em Ciências Ambientais Embrapa/UNIR.

${ }^{25}$ Química. Dra em Biologia Experimental. Departamento de Zootecnia da Universidade Federal de Rondônia. fernandabay@unir.br 
sendo desenvolvida e praticada de maneira responsável a aquicultura pode gerar benefícios duradouros a segurança alimentar mundial e ao crescimento econômico.

O Brasil é um dos poucos países que possui condições de atender à crescente demanda mundial por produtos de origem pesqueira, sobretudo por meio da aquicultura. Na Região Norte onde a aquicultura está se desenvolvendo com rapidez, em 2009, Rondônia ocupou a $3^{\circ}$ posição na produção de pescado (8.178,1 ton.), baseada principalmente no cultivo de tambaquis (Colossoma macropomum) em tanques escavados (MPA, 2010). De acordo com estatísticas da Secretaria de Desenvolvimento Ambiental de Rondônia - SEDAM (2013), Rondônia se destaca como o maior produtor de peixes de água doce, cultivando 10.805 hectares de lâmina de água, com uma produção estimada em 64.833 toneladas de pescados por ano (G1-Rondônia, 2014).

Em 2013 ocupou a primeira posição do país na produção de tambaqui, sendo os municípios de Ariquemes, Mirante da Serra e Urupá seus principais produtores, conforme a Secretaria de Estado da Agricultura, Pecuária e Regularização Fundiária - Seagri, na safra 2012/2013, Rondônia teve uma produção aproximada de 48 mil toneladas de tambaqui, com estimativa para 2014 de 70 mil toneladas. Os principais compradores do peixe rondoniense são os estados como Amazonas, Piauí, Maranhão, Rio de Janeiro, São Paulo e o Distrito Federal (G1-Rondônia, 2014).

A qualidade da água é preocupação constante em criações de peixes, quando esta é de má qualidade, pode ocorrer quedas no desempenho produtivo e mortalidade dos peixes, diminuindo produção e a lucratividade (BACCARIN, 2002).

O viveiro de piscicultura funciona como um ecossistema artificial onde as condições abióticas e bióticas podem ser parcialmente manipuladas (MARTINS, 2007), abrigando uma comunidade biótica bem diversificada, desde produtores primários, a produtores secundários e decompositores (OSTI, 2009). Neste encontrase o plâncton que é composto por organismos animais (zooplâncton) e vegetais (fitoplâncton) (KUBITZA, 1998).

O fitoplâncton possui importante papel na produção primária do meio aquático, abrange um conjunto de organismos diversificados a nível taxonômico, morfológico e fisiológico, que apresentam diferentes requisitos e respostas as variáveis físicas e químicas da água, como a luz, temperatura, alcalinidade, concentração de nutrientes, pH, oxigênio, etc. (LUÍS, 2011). Este produz de 50 a 95\% do oxigênio nos sistemas aquaculturais, no entanto, o plâncton chega a consumir cerca de 50 a $80 \%$ do OD em processos respiratórios, sendo o equilíbrio entre a fotossíntese e a respiração um pré-requisito para a manutenção constante da composição química da água (KUBITZA, 1998). 
O processo de eutrofização pode ocorrer naturalmente, ou por ação antrópica, causada pela deposição de material poluente (ESTEVES, 1998). Um ambiente aquático é eutrófico quando apresenta uma quantidade excessiva de nutrientes, em especial compostos nitrogenados e fosfatados, que contribuem na degradação do equilíbrio ecológico e da qualidade da água (ANDRADE, 2008). O enriquecimento artificial dos corpos d'água, principalmente com tais compostos, promovem 0 crescimento excessivo de algas e plantas aquáticas, muitas vezes ocasionando mortandade de peixes, devido ao déficit de OD na água (MERCANTE et al, 2008; OSTI, 2009).

A assimilação de amônia, nitrato e fósforo pelo fitoplâncton pode acarretar um crescimento descontrolado desta comunidade provocando florações de algas no ambiente, que se forem originadas por determinadas espécies de cianobactérias que são capazes de liberar compostos potencialmente tóxicos na água, podem gerar dificuldades no tratamento da mesma (MULLER et al 2012).

A deficiência de conhecimentos básicos sobre a qualidade da água faz com que os próprios produtores contribuam para a queda na qualidade desta, pois, nos tanques e viveiros com baixa renovação de água, é inevitável o acúmulo de resíduos orgânicos e metabólicos gerados durante o processo produtivo, sendo assim o desafio do produtor minimizar o acúmulo de resíduos durante o cultivo, evitando assim uma rápida degradação da qualidade da água, de forma a obter um melhor desempenho dos peixes e maior produtividade (KUBITZA, 2003).

A palavra limnologia vem do grego limné, que significa lago, é definida como o estudo ecológico de todas as massas d'águas continentais, independentemente de suas origens, dimensões e concentrações salinas, tendo por objetivo estudar os ecossistemas aquáticos como um todo. O conhecimento da importância da limnologia vem sendo reconhecida nos últimos anos conjuntamente com o próprio crescimento da aquicultura, trazendo consigo a preocupação com o regime e a qualidade dos mananciais, bem como a manutenção da boa qualidade da água em tanques e viveiros, sendo a aplicabilidade dos conhecimentos limnológicos a chave para o sucesso de uma produção aquícola racional (ESTEVES, 1998).

\section{Importância da qualidade da água na piscicultura}

A água constitui um dos compostos de maior distribuição e importância na crosta terrestre, sua importância para a vida está no fato de que nenhum processo metabólico ocorre sem a sua ação direta ou indireta, foram suas propriedades que 
possibilitaram o surgimento e a manutenção da vida na terra (ESTEVES, 1998). A água é a única substância que aparece com abundância na Terra nos três estados físicos: sólido (forma o gelo dos glaciares e das calotas polares e cobre os picos das montanhas mais altas); líquido (cobre aproximadamente 3/4 da superfície terrestre, os oceanos possuem $28,3 \times 10^{20}$ litros de água) e gasoso (em toda a atmosfera terrestre). A água está presente também nos animais, vegetais e como "água de hidratação" em muitos minerais. Pode ser doce ou salgada, e disposta como lago, córrego, rio, mar ou oceano, entre outros (LENZI, 2009).

O termo "água" refere-se ao elemento natural desprovido de qualquer utilização, já o termo recurso hídrico refere-se à utilização da água como bem econômico. Os recursos hídricos são destinados ao abastecimento do consumo humano e as atividades produtivas, sendo captados a partir de rios, lagos, represas e aquíferos subterrâneos. Estas águas são encontradas em domínio terrestre, nos continentes e ilhas, formando a hidrosfera, sendo que $97,5 \%$ desta camada é formada por água salgada e 2,5\% água doce, sendo rios e lagos responsáveis por somente $0,3 \%$ deste último percentual (REBOLÇAS, 2002).

Ao compartilhar de tão grande quantidade de água, o homem julga este bem inesgotável e apenas nos últimos anos tem se conscientizado de que, a água não é só preciosa e esgotável como também deve ser preservada e usada com moderação, uma vez que, a demanda pelo consumo de água vêm aumentando. Todavia, os corpos d'água nos últimos anos estão sendo cada vez mais poluídos devido à atuação das atividades antrópicas.

Sendo um dos componentes básicos dos ciclos geoquímico e biogeoquímico, a água sempre terá em solução espécies químicas que podem ser poluentes ou não, várias são as fontes de poluição dos mananciais superficiais ou subterrâneos, sendo elas naturais ou provocadas pelo homem, em geral a fonte ou a origem do poluente está longe do corpo d'água, pois, dentro do ciclo biogeoquímico a hidrosfera possui capacidade de dissolver, deslocar e transportar os poluentes (LENZI, 2009).

A América do Sul como um todo, em particular para o Brasil, concentra as maiores bacias hidrográficas do mundo. $O$ território brasileiro concentra aproximadamente 12 a $15 \%$ de toda água doce disponível no planeta. A água no entanto é um recurso natural reciclável, mas não renovável (CYRINO et al, 2010). Muitos cientistas, conforme Esteves (1998), já afirmaram há tempos que o principal problema para o futuro da humanidade não estará na escassez de combustíveis fósseis, mas sim, no déficit de água doce. Porém, seu uso indiscriminado associado à deterioração de sua qualidade intensifica a sua escassez, assim, há necessidade de maior cuidado com a utilização de água proveniente de sistemas de criação de organismos aquáticos, não só melhorando o manejo empregado, mas também adotando sistemas que auxiliem na melhoria da qualidade da água (MILLAN, 2009). 
Uma vez que, na atividade de piscicultura a disponibilidade e qualidade da água são fatores fundamentais. Apesar de aparentemente óbvio, $\mathrm{O}$ ambiente aquático é o meio onde os peixes vivem e desenvolvem-se, estão em constante contato com a água, utilizando-a para a obtenção de oxigênio e liberação de gás carbônico, além de resíduos nitrogenados e outras substâncias de excreção (MORO et al 2013).

O impacto da piscicultura é quase desprezível em comparação ao impacto ambiental de efluentes domésticos e industriais (CYRINO et al 2010). No entanto a contaminação das águas superficiais com a entrada de poluentes, rejeitos oriundos das atividades humanas nos corpos hídricos altera os diversos componentes presentes na água, promovendo modificações em suas características físicas, químicas e biológicas (JARDIM, 2011). Segundo Kubitza (2003), condições inadequadas de qualidade da água prejudicam o crescimento, reprodução, saúde, sobrevivência e até mesmo a qualidade dos peixes, de modo que, a habilidade dos produtores e técnicos em monitorar e corrigir a qualidade da água é um fator decisivo no sucesso dos empreendimentos aquícolas da água nos viveiros e taques de cultivos.

Desse modo, a análise de parâmetros físicos e químicos da água constitui uma importante ferramenta para monitorar a qualidade hídrica do sistema (MATSUZAKI et al, 2004). Dentre os parâmetros mais estudados destacam-se: potencial hidrogeniônico $(\mathrm{pH})$, Oxigênio Dissolvido (OD), temperatura $(\mathrm{T})$, alcalinidade, condutividade elétrica, nitrogênio $\left(\mathrm{NH}_{3}, \mathrm{NH}_{4} \mathrm{e} \mathrm{NO}_{2}{ }^{1-}\right)$ e fósforo ( $\mathrm{P}$ e $\mathrm{PO}_{4}{ }^{3-}$ ) e, transparência.

\section{Potencial hidrogeniônico (pH)}

Em regra geral, valores de $\mathrm{pH}$ próximos à neutralidade $(6,5$ a 8,0$)$ são mais adequados à produção de peixes, valores muito acima ou abaixo desta faixa podem causar prejuízos ao crescimento, reprodução e saúde dos mesmos, e em condições extremas ocasionar considerável mortandade de peixes (KUBITZA, 2003). O valor ideal de $\mathrm{pH}$ depende das diferentes espécies de peixe, onde valores inferiores a 6,5 ou superiores a 8,5 causam problemas fisiológicos diversos. Já o $\mathrm{pH}$ na água varia de acordo com outros parâmetros de sua qualidade com a alcalinidade e a dureza (MORO et al 2013). 


\section{Oxigênio dissolvido (OD)}

Elemento vital para sobrevivência de diversas formas de vida, o oxigênio pode ser um dos fatores limitantes na produtividade dos sistemas de cultivo de peixes, deste modo as concentrações de oxigênio dissolvido devem ser mantidas acima de 4,0 mg. $\mathrm{L}^{-1}$ (KUBITZA, 2003), valores abaixo geralmente causam estresse aos peixes, reduzindo o consumo de alimento e resistência a doenças (MASSER et al, 1993). Já para Moro et al (2013)., para as espécies de águas frias, a concentração de oxigênio dissolvido na água deve ser sempre superior a $5,0 \mathrm{mg} \cdot \mathrm{L}^{-1}$ e para as espécies de águas quentes (tropicais), o ideal é uma concentração acima de 3,0 mg.L-1. Níveis de oxigênio abaixo de 1,0 mg.L-1 são letais para a maioria das espécies, se expostas por muitas horas a essa situação.

As principais fontes de oxigênio na água são diretamente da atmosfera, que penetra por ação mecânica provocada pelos ventos, correntes ou declividades. Outra fonte que contribui de maneira notável para a oxigenação da água é a ação fotossintética das plantas clorofiladas. Sendo a luz indispensável para este processo, o oxigênio é produzido unicamente nas horas do dia e somente até onde a luz possa penetrar na coluna de água (GURGEL; VINATEA, 1998).

\section{Temperatura (T)}

A temperatura, importante variável para a vida aquática e metabolismo do sistema, interfere diretamente na solubilidade dos gases (BRANCO, 1986 apud ANDRADE, 2008) bem como, no crescimento e desenvolvimento animal e vegetal, devido à influência sobre as reações químicas, está intimamente relacionada com as condições climáticas locais, dentre os quais a mais importante para tanques rasos é a quantidade de radiação solar incidente (MILLAN, 2009).

Há uma faixa de conforto térmico adequada para os peixes, a qual varia dependendo da espécie e do estágio de desenvolvimento em que se encontram, onde a preferência de uma espécie se dará na faixa de temperatura que corresponde ao valor ideal para o seu crescimento e bem estar. Temperaturas abaixo ou acima dessa faixa inibem o apetite e o crescimento dos peixes, além de favorecer a incidência de doenças. Para as espécies de clima tropical, a faixa favorável à prática da piscicultura varia de 26 a $30^{\circ} \mathrm{C}$. As espécies amazônicas, como o tambaqui (Colossoma macropomum) e o pirarucu (Arapaima gigas), preferem temperaturas 
mais próximas a $28^{\circ} \mathrm{C}$. Já espécies do Sul do Brasil, como o jundiá (Rhamdia quelen), temperaturas ao redor de $24^{\circ} \mathrm{C}$ será o mais apropriado (MORO et al 2013).

\section{Alcalinidade}

A alcalinidade total da água (expressa em $\mathrm{mg}^{-\mathrm{L}^{-1}}$ de carbonato de cálcio $\left(\mathrm{CaCO}_{3}\right)$ ), é derivada principalmente da dissolução do calcário dos solos e a sua concentração é determinada principalmente pelas características do solo, de modo que, viveiros em áreas com solos arenosos frequentemente apresentam uma alcalinidade total abaixo de $20 \mathrm{mg} \cdot \mathrm{L}^{-1}$, enquanto os viveiros construídos em áreas com solos calcários podem apresentar uma alcalinidade total acima de $100 \mathrm{mg.L} \mathrm{L}^{-1}$. Outros fatores como o clima também influenciam, como por exemplo, os viveiros localizados em regiões áridas possuem solos com maior alcalinidade total do que viveiros localizados em regiões úmidas (QUEIROZ; BOEIRA, 2006).

Segundo Moro et al. (2013), baixa alcalinidade pode proporcionar variações no $\mathrm{pH}$ ao longo do dia. No entanto, o ideal é que as águas de sistema de piscicultura apresentem uma alcalinidade total maior que $20 \mathrm{mg}$ de $\mathrm{CaCO}_{3} / \mathrm{L}$, sendo o nível ideal em torno de $40 \mathrm{mg}$ de $\mathrm{CaCO}_{3} / \mathrm{L}$ por proporcionar adequada capacidade de tampão ou buffer da água, evitando a redução do $\mathrm{pH}$ devido ao aumento da taxa respiratória nos viveiros. Valores de $\mathrm{pH}$, dureza e alcalinidade altos normalmente não causam problemas para os peixes, entretanto valores baixos ocasionam sérios problemas nos animais e em casos extremos a morte de todos os peixes. Valores abaixo do ideal, é indicada a aplicação de 3 ton/ha de calcário agrícola, 2 ton/ha quando o $\mathrm{pH}$ de uma mistura (parte de solo do fundo do viveiro mais uma parte de água), estiver entre 5 e 6 e 1 ton/ha quando o pH dessa mistura estiver entre 6 e 7.

\section{Condutividade elétrica}

A condutividade elétrica de uma solução é a capacidade desta em conduzir a corrente elétrica, ou seja, a capacidade de condução desta corrente se dá em função dos íons presentes na água, no entanto é de se esperar que em soluções de maior concentração iônica, maior será a condutividade elétrica, exceto em águas muito puras onde ocorre o processo inverso (ESTEVES, 2011). 
Na composição iônica em geral os principais cátions constituintes são o cálcio $\left(\mathrm{Ca}^{2+}\right)$, magnésio $\left(\mathrm{Mg}^{2+}\right)$, sódio $\left(\mathrm{Na}^{+}\right)$, potássio $\left(\mathrm{K}^{+}\right)$, ferro $\left(\mathrm{Fe}^{3+}\right)$, e o manganês $\left(\mathrm{Mn}^{2+}\right)$ e os principais ânions são o cloreto $\left(\mathrm{Cl}^{-}\right)$, sulfato $\left(\mathrm{SO}_{4}{ }^{2-}\right)$, carbonato $\left(\mathrm{CO}_{3}{ }^{2-}\right)$ e bicarbonato $\left(\mathrm{HCO}_{3}{ }^{-}\right)$. Vários fatores podem influenciar na composição iônica dos corpos d'água, como: a geologia da área de drenagem dos efluentes, geologia da bacia de acumulação do lago e regime de chuvas, bem com também o tipo de influência antrópica à qual estes corpos d'água estão submetidos (ESTEVES, 2011).

\section{Nitrogênio $\left(\mathrm{NH}_{3}, \mathrm{NH}_{4}\right.$ e $\left.\mathrm{NO}_{2}{ }^{1-}\right)$}

O nitrogênio é considerado um dos elementos mais importantes no metabolismo dos ecossistemas aquáticos, em razão de sua participação na formação de proteínas, podendo atuar como fator limitante da produção primária desses ecossistemas e, em determinadas condições, tornar-se tóxico para os organismos aquáticos. Dentre os compostos nitrogenados dissolvidos na água, encontra-se uma forma ionizada, $\mathrm{NH}_{4}{ }^{1+}$, denominada íon amônio, ou simplesmente amônio, e outra não ionizada, $\mathrm{NH}_{3}$, amplamente conhecida como amônia. As duas formas juntas constituem a amônia total, ou nitrogênio amoniacal total (PEREIRA; MERCANTE, 2005).

$\mathrm{Na}$ forma nitrito $\left(\mathrm{NO}_{2}{ }^{1-}\right)$, este pode causar mortalidade nos organismos aquáticos, pois em elevadas concentrações no meio aquático pode causar a oxidação do ferro da hemoglobina (o ferro passa do estado ferroso $\mathrm{Fe}^{+2}$ para o estado férrico $\mathrm{Fe}^{+3}$ ), transformando-a em metahemoglobina, comprometendo a capacidade de transporte de $\mathrm{O}_{2}$ para os tecidos, matando o indivíduo por asfixia e cianose (WAMBACH, 2012).

O nitrogênio presente nos viveiros pode estar dissolvido ou particulado, pode ser de origem orgânica ou inorgânica oriundo da decomposição de matéria orgânica e resultado de intemperismo dos solos, bem como, incorporado aos tanques de maneira artificial pela adição de fertilizantes orgânico e inorgânicos e por águas residuais de atividades pecuárias (MORO et al 2013). 


\section{Fósforo $\left(\mathrm{Pe} \mathrm{PO}_{4}{ }^{3-}\right)$}

A dinâmica dos nutrientes, principalmente nitrogênio e fósforo, possuem efeito direto na biota aquática, interferindo no crescimento e desenvolvimento dos organismos planctônicos e macrófitas, na maioria das águas continentais o fósforo é o principal fator limitante da produtividade, além disso, este elemento tem sido apontado como o principal responsável pela eutrofização artificial destes ecossistemas (ESTEVES, 1998).

O ciclo do fósforo é considerado o mais crítico da produção orgânica por ser fator limitante e também porque sua carga é facilmente consumida pelo fitoplâncton, sendo que a sustentabilidade de uma piscicultura depende, entre outros fatores, da avaliação e manutenção constante dos níveis de fósforo. O fósforo presente nos ambientes aquáticos é de origem natural ou artificial, sendo no caso da piscicultura em sua grande maioria de origem artificial (arraçoamento) (PEREIRA; RIBEIRO FILHO, 2004).

\section{Transparência}

Na água, a luz é utilizada pelo fitoplâncton para a realização da fotossíntese, onde a energia luminosa é transformada pelos organismos em matéria orgânica, logo havendo liberação de oxigênio. $O$ ideal para ambientes de cultivo é que a transparência esteja entre 40 a $60 \mathrm{~cm}$ e seu monitoramento deve ser realizado pelo menos uma vez por semana, uma vez que durante o período noturno não há produção se oxigênio (MORO et al 2013).

O monitoramento da transparência da água do viveiro é importante, principalmente quando não se dispõe de medidores de oxigênio e nem de sistemas de aeração para eventuais emergências, porque permite acompanhar a concentração da população planctônica. Assim, o piscicultor pode prever e evitar possíveis diminuições na concentração de OD na água, principalmente no período noturno, quando o fitoplâncton cessa o processo de fotossíntese e consequentemente para de produzir oxigênio (FARIA et al, 2013). 


\section{Importância do fitoplâncton na qualidade da água}

A comunidade fitoplanctônica é caracterizada por um grupo diversificado de organismos fotossintetizantes, ou não, encontrados em ambientes marinhos, de água doce, de água salobra, solos entre outros. Sua identificação é auxiliada principalmente pelos tipos de pigmentos fotossintéticos, produtos de reserva, aspecto da parede celular, morfologia, citologia, ciclo de vida entre outras características (HOEK et al, 1997 apud CORRÊA, 2011).

Nos ambientes de água doce, há coexistência de um grande número de espécies de algas fitoplanctônicas. Geralmente, duas ou mais espécies tornam-se dominantes no ambiente, enquanto conjuntamente pode ser encontrado um grande número de espécies raras e subdominantes (MULLER, 2012).

Em águas interiores podem ser encontrados representantes de praticamente todos os grupos de algas. A predominância de um ou outro grupo em determinado ecossistema é uma função, principalmente, das características predominantes do meio, como por exemplo, em lagos distróficos (ricos em compostos húmicos) por via de regra ocorre predominância de algas Chlorophyta, representadas pelas Desmidiaceae. Os principais grupos com representantes no plâncton de água doce são: Cyanophyta, Chlorophyta, Euglenophyta, Chrysophyta e Pyrrophyta (ESTEVES, 1998).

As mudanças constantes do ambiente e as relações entre espécies, não proporcionam um ambiente uniforme por períodos longos de tempo, ocasionando um processo lento de exclusão competitiva e gerando um equilíbrio misto de populações. A composição final da comunidade fitoplânctonica é consequência de um balanço entre perdas e ganhos dentro do grupo de espécies que apresentam adaptações para sobreviver no ambiente (MULLER, 2011).

Segundo Vicente et al. (2005) a composição e abundância do fitoplâncton em lagos e reservatórios depende dos seguintes fatores: condições físicas e hidrológicas (luz, temperatura, turbulência/estabilidade de plâncton); composição química da água (nutrientes e mineralização da matéria orgânica (compostos em constante de proporcionalidade), $\mathrm{pH}$, oligoelementos, fatores biológicos (predação por parte de filtradores planctófagos (zooplâncton e peixe), relações entre espécies (efeito alelopático e toxicidade induzida por algumas espécies) e o parasitismo de fungos (infecções por fungos e flagelados heterotróficos cromistas capazes de reduzir densas populações fitoplactônicas). 
Segundo Muller (2012), os fatores ambientais mais importantes que interferem e regulam o desenvolvimento de organismos que são selecionados mais adaptados à condição particular do ambiente, são a intensidade luminosa, temperatura, sedimentação e distribuição vertical dos organismos na coluna d'água, disponibilidade de nutrientes no meio aquático, competição e alelopatia com demais produtores primários, além da predação pelo zooplâncton.

A variação temporal do fitoplâncton em lagos tropicais, segundo Esteves (1998), é um dos fatores controladores mais importantes na disponibilidade de nutrientes e radiação subaquática, porém em lagos e represas tropicais de baixa profundidade, ambientes geralmente sujeitos a muita turbulência, torna-se difícil o reconhecimento dos fatores mais importantes na determinação das variações temporais. Hino (1979) apud Esteves (1998) sugere como principais fatores da variação temporal a precipitação total, predação seletiva e a reciclagem de nutrientes, que neste ecossistema está associada à turbulência da coluna d'água. Conforme Sipaúba-Tavares (1995) apud Mercante (2005) a sazonalidade do fitoplâncton está diretamente associada às concentrações de fósforo e nitrogênio na água, os quais resultam das práticas de fertilização, manejo ou taxas de alimentação nos cultivos comerciais.

A comunidade aquática fitoplanctônica responde rapidamente às alterações ambientais, seja pela redução de espécies, ou pela ocorrência de florações, isto é, aumento da biomassa de uma ou mais espécies presentes no ambiente (MULLER, 2012). O monitoramento das condições físicas, químicas e biológicas é importante, mas a classificação das algas, com suas flutuações no espaço e no tempo, é fundamental para a identificação das épocas favoráveis aos florescimentos e à concentração de toxinas na água (TUNDISI, 2003).

\section{Manejo e monitoramento da qualidade da água em piscicultura}

Em condições de variações nos níveis de oxigênio, onde a concentração esteja abaixo de 1,0 mg. $\mathrm{L}^{-1}$ é recomendável a utilização de aeradores nos tanques ou aumentar a vazão de entrada de água do viveiro proporcionando uma renovação mais rápida e também reduzindo a concentração dos compostos nitrogenados $\left(\mathrm{NH}_{3}\right)$, $\left(\mathrm{NO}_{2}{ }^{-}\right)$e $\left(\mathrm{NO}_{3}{ }^{-}\right)$na água. Em tanques com problemas na alcalinidade, a dose de calcário suficiente para adequar os valores deste parâmetro é de $200 \mathrm{~kg} / 1000 \mathrm{~m}^{2}$. Em tanques com nível de transparência abaixo do indicado, deve-se realizar a adubação orgânica em torno de $2500 \mathrm{~kg} / \mathrm{ha}$ (cama de frango), $4000 \mathrm{~kg} / \mathrm{ha}$ (esterco suíno curtido) e $6000 \mathrm{~kg} / \mathrm{ha}$ (esterco bovino curtido) e adubação química em torno de 
$30 \mathrm{~kg} / \mathrm{ha}$ (superfosfato simples), $15 \mathrm{~kg} / \mathrm{ha}$ (cloreto de potássio) e $30 \mathrm{~kg} / \mathrm{ha}$ (uréia), aplicados ao mesmo tempo (MORO et al 2013).

O sistema de fluxo contínuo (raceway) de abastecimento de água na piscicultura tem por finalidade reduzir os teores das formas nitrogenadas e fosfatadas da água, por diluição e carreamento. Este processo causa ligeira agitação na coluna de água, favorecendo o processo de nitrificação, diminuindo, assim, a concentração de nitrito e aumentando a de amônia e nitrato, que é assimilado por macrófitas e algas, consequentemente modificando a estrutura das comunidades e os processos internos do sistema (SIPAÚBA-TAVARES et al, 2008 apud MILLAN, 2009). Geralmente, estes sistemas são em tanques retangulares ou circulares de concreto ou outro material que resistam ao atrito constante da água em suas paredes, são rasos e permitem uma grande densidade de estocagem (CREPALDI et al 2006).

No entanto, poucos estudos têm enfatizado os efeitos adversos do sistema de fluxo contínuo, de modo que, conforme Millan (2009), uma vez que a água de um tanque entra em contato com a água de outro tanque rico em nutrientes, matéria orgânica e sólidos em suspensão, pode-se causar problemas de eutrofização e sedimentação devido ao efeito acumulativo.

$\mathrm{Na}$ piscicultura, o monitoramento da qualidade da água constitui ferramenta importante, pois permite verificar em que situação se encontra o corpo d'água, possibilitando a avaliação da oferta hídrica e conferindo bases para decisões de aproveitamento múltiplo e integrado desta, bem como a minimização de impactos ao ambiente (COIMBRA, 2001). Os parâmetros da qualidade a água devem ser monitorados com o uso de kits, sondas multiparâmetros, disco de Secchi, bem como, nas condições, frequências e horários ideais para a realização das medidas (MORO et al 2013).

Estratégias para minimizar o impacto da aquicultura no ambiente estão sendo desenvolvidas como a manipulação de dietas formuladas, implantação de biofiltros para retenção dos nutrientes, monitoramento da qualidade da água, adoção de tecnologia adequada para cada local específico, remoção de sólidos e entre outros (PIEDRAHITA, 2003 apud MILLAN, 2009). Há também práticas de manejo que minimizam impacto ao ambiente, como utilizar rações de alta qualidade, fornecer alimento na quantidade adequada evitando sobras na água, utilizar adequadas taxas de lotação (densidade de estocagem) e sistemas de tratamento de água (MORO et al 2013).

Neste contexto, visando preservar a qualidade dos corpos hídricos e auxiliar produtores e técnicos, o Conselho Nacional do Meio Ambiente - CONAMA aprovou a resolução 357 em 17 de março de 2005 (BRASIL, 2005), que estabelece limites aceitáveis para diversos parâmetros da água, classificando o corpo hídrico de acordo 
com o seu uso, de modo que a classificação padroniza os corpos d'água e permite o estabelecimento de metas para se atingir o nível de qualidade desejada, fixando limites para parâmetros de qualidade de água em efluentes, incluindo a aquicultura.

\section{Considerações finais}

Tendo em vista que a disponibilidade da água e sua qualidade são fatores fundamentais para a atividade piscícola, torna-se necessário regularmente a correção e o monitoramento nos tanques de piscicultura, de forma a propiciar condições adequadas de cultivo, garantindo bom desempenho zootécnico dos peixes, como crescimento, reprodução, saúde e sobrevivência.

No entanto a qualidade desta em condições adequadas não só reflete de maneira positiva na produção aquícola, evitando prejuízos econômicos aos produtores devido ao descuido por falta de informações técnicas, bem como contribui para a minimização dos impactos ambientais, mantendo o equilíbrio dos ecossistemas, a diversidade natural dos corpos d'água receptores e atuando no tratamento dos efluentes de piscicultura resultante dos sistemas de produções de peixes.

\section{Referências}

ANDRADE, R.S. Dinâmica do fitoplâncton, qualidade de Água e a percepção ambiental da Comunidade de pescadores em açudes da Bacia do rio Taperoá.150p. Dissertação (Mestrado). Universidade Federal da Paraíba. João Pessoa, 2008.

BACCARIN, A.E. Impacto ambiental e parâmetros zootécnicos da produção de tilápia do Nilo (Oreochromis niloticus) sob diferentes manejos alimentares. Dissertação (Doutorado). 2002. 56p. Universidade Estadual Paulista - UNESP, Jaboticabal, 2002.

CONAMA, Resolução 357 de 17 de Março de 2005. Dispõe sobre a classificação dos corpos d'água e diretrizes ambientais para o seu enquadramento, bem como estabelece as condições e padrões de lançamento de efluentes. Diário Oficial da República Federativa do Brasil, Brasília, DF, 18 de março de 2005. 
COIMBRA, R.M. Monitoramento da qualidade da água. In: Porto, R. L. Hidrologia ambiental. São Paulo: EDUSP; Associação Brasileira de Recursos Hídricos. 2001. p.391-411.

CORREAA, R.G. Flora Filtoplanctônica e do Sedimento em Piscicultura Comercial de Catfish (Ictalurus Punctatus), no Municipio de Palhoça, SC, Brasil. 2011. 89p. Dissertação (mestrado) - Centro de Ciências Agrárias, Universidade Federal de Santa Catarina. Florianopolis, 2011.

CREPALDI, D. V.; TEIXEIRA E. A.; FARIA P. M. C.; RIBEIRO L. P.; MELO D. C.; CARVALHO D.; SOUSA A. B.; SATURNINO H. M. Sistemas de produção na piscicultura. Revista Brasileira Reprodução Animal, v.30, n.3/4, p.86-99, 2006.

CYRINO, E.P.C.; BICUDO Á. J. A.; SADO R. Y.; BORGHESI R.; DAIRIKI J. K. A piscicultura e o ambiente - o uso de alimentos ambientalmente corretos em piscicultura. Revista Brasileira de Zootecnia, vol.39 supl.especial, p.68-87, Viçosa, 2010.

ESTEVES F.A. Fundamentos de Limnologia. Rio de Janeiro, Interciência, $3^{a}$ ed., 790p, 2011.

FAO - Organización de las Naciones Unidas para la Alimentación y la Agricultura. EL ESTADO MUNDIAL DE LA PESCA Y LA ACUICULTURA: OPORTUNIDADES Y DESAFÍOS. ROMA. 2014. Disponível em < http://www.fao.org/3/a-i3720s.pdf> Acesso em junho/2014.

FARIA, R. H. S. A. de; MORAIS, M.; SORANNA, M. R. G. de S.; SALLUM, W. B. Manual de criação de peixes em viveiro. Brasília: Codevasf, 136 p. 2013.

G1-Rondônia. RO é líder na produção nacional de tambaqui e destaque na piscicultura.. 2014. Disponível em: < http://g1.globo.com/ro/rondonia/noticia/2014/03/ro-e-lider-naproducao-nacional-de-tambaqui-e-destaque-na-piscicultura.html>. Acesso em: $11 \mathrm{abr}$. 2014.

GURGEL, J. J. S.; VINATEA, J. E.; Métodos de aumento da produtividade aquática natural. Manual sobre manejo de reservatorios para a produção de peixes. Documento de Campo 9, GCP/RLA/075/ITA, Brasília, Brasil, 1988.

JARDIM, B. F. M. Variação dos parâmetros físicos e químicos das águas superficiais da Bacia do Rio das Velhas-MG e sua associação com as florações de cianobactérias. Dissertação (mestrado) - UFMG, Escola de Engenharia. 2011.

KUBITZA F. Qualidade da água na produção de peixes - Parte II. Panorama da Aquicultura, março/abril, 1998. 
KUBITZA F. Qualidade da água no cultivo de peixes e camarões. Jundiaí, 229p. 2003.

LENZI, E.; FAVERO, L. O. B.; LUCHESE, E. B. Introdução à química da água: ciência, vida e sobrevivência. Rio de Janeiro: LTC, 2009. 632p.

LUÍS, C. S. C. Fitoplâncton do estuário do Mondego segundo a diretiva - quadro da água. 2011, p. 77, Dissertação (Mestrado); Departamento de Ambiente e Ordenamento, Universidade de Aveiro, Faro - Portugal. 2011.

MARTINS, Y. K. Qualidade da água em viveiro de tilápia do Nilo (Oreochromis niloticus) caracterização diurna de variáveis físicas, químicas e biológicas. 2007. 43p. Dissertação (Mestrado) - Instituto de Pesca, Agência Paulista de Tecnologia dos Agronegócios, Secretaria de Agricultura e Abastecimento. - São Paulo, 2007.

MASSER, M. P.; CICHRA E.; GILBERT, R. J. Fee-fishing ponds: management of food fish and water quality. Southern Regional Aquaculture Center, v. 480, p. 1-8, 1993.

MATSUZAKI, M.; MUCCI, J. L. N.; ROCHA, A. A. Comunidade fitoplanctônica de um pesqueiro na cidade de São Paulo. Revista de Saúde Pública, v. 38, n. 5, p. 679-686, 2004.

MERCANTE, C. T. J.; ESTEVES K. E.; PEREIRA J. S.; OSTI J. S. Limnologia na aquicultura: estudo de caso em pesqueiros. 2008. Disponível em <www.pesca.sp.gov.br>. Acesso: 126/03/2014.

MERCANTE, C. T. J.; COSTA S. V.; SILVA D. DA; CABIANCA M. Â.; ESTEVES K. E.. Qualidade da água em pesque e pague da região metropolitana região metropolitana região metropolitana de São Paulo (Brasil): avaliação através de fatores abióticos (período seco e chuvoso). Acta Scientiarum. Biological Sciences. v. 27 , no. 1, p. 1-7, 2005.

MILLAN, R.N. Dinâmica da qualidade da água em tanques de peixes de sistema pesque-pague: aspectos físico-químicos e plâncton. 2009. 97p. Dissertação (Mestrado) - UNESP, São Paulo. 2009.

MORO, V.M.; TORATI, L.S.; LUIZ, D.B.; MATOS, F.T. Monitoramento e manejo da qualidade da água em piscicultura. In: RODRIGUES, A. P. O. [et al.] (Org.) Piscicultura de água doce: multiplicando conhecimentos. Brasília, DF: EMBRAPA, 2013. p. 141-168.

MPA - Ministério da Pesca e Aquicultura. Amazônia Aquicultura e Pesca: Plano de Desenvolvimento Sustentável. Brasília - DF, p. 01-28, 2010. 
MULLER, C.C.; CYBIS, L.F.; RAYA-RODRIGUEZ, M.T. Monitoramento do Fitoplâncton para a Qualidade da Água de Abastecimento Público - Estudo de Caso de Mananciais do Rio Grande do Sul. RBRH - Revista Brasileira de Recursos Hídricos, v. 17 n.2 - Abr/Jun 2012, 203-211.

ONO, E.A.; KUBITZA, F. Cultivo de peixes em tanques-rede. 3.ed. Jundiaí, SP: Esalq - USP, 2003. 112 p.

OSTI, J. A.S. Caracterização da qualidade da água e avaliação do manejo e suas implicações sobre o cultivo de tilápias (Oreochromis niloticus). 2009. 60p. Dissertação (mestrado), Programa de Pós-graduação em Aquicultura e Pesca do Instituto de Pesca - APTA. São Paulo - SP.

PEREIRA, J.M.A.; RIBEIRO FILHO, R.A. Efeitos da excreção de tilápias (Tilápia rendalli e Oreochromis niloticus) em reservatórios e viveiros de Piscicultura. In: ESPÍNDOLA, E.L.G.; SCHALCH, V. (Org.) Bacia Hidrográfica: diversas abordagens em pesquisa, RiMa, 2004, p.99-110.

PEREIRA, L.P.F.; MERCANTE, C.T.J. A amônia nos sistemas de criação de peixes e seus efeitos sobre a qualidade da água. Uma revisão. Boletim do Instituto de Pesca, v.31, n.1, p. 81-88, 2005.

QUEIROZ, J.F.; BOEIRA, R.C. Calagem e Controle da Acidez dos Viveiros de Aquicultura. Jaguariúna: Embrapa Meio Ambiente, 2006. 8 p. (Embrapa Meio Ambiente. Circular Técnica, 14).

REBOLÇAS, A.C. Água doce no mundo e no Brasil. In: Águas doces no Brasil: capital ecológico, uso e conservação. 2 ed. São Paulo: Escrituras Editora, 703 p., 2002.

TUNDISI, J. G. Água no século XXI: enfrentando a escassez. São Carlos: RiMa, IIE, 2003. 248p.

VICENTE, E.; Metodología para el establecimiento el estado ecológico según la directiva marco del agua. Protocolo de confederacion hidrografica del ebro. 2005.

WAMBACH, X. F. Manejo Prático Aplicado a Piscicultura de Água Doce. Apostila, 28 f. Departamento de Zootecnia. Universidade Federal Rural de Pernambuco, Recife PE, 2012. 


\section{Desenvolvimento da carcinicultura no Brasil}

Yuri Vinicius de Andrade Lopes ${ }^{26}$

\section{Aquicultura Mundial}

O cultivo racional de organismos aquáticos, atividade fito e zootécnica mais conhecida como aquicultura, é uma prática antiga, com 4.000 a 5.000 anos de história. Apesar disso, foram somente nos últimos 30 anos que experimentou um significativo incremento, tornando-se, nessa virada de milênio, a atividade agropecuária que mais cresceu no mundo inteiro. Durante os últimos anos, um grande esforço foi feito para introduzir práticas responsáveis na aquicultura. Códigos de Conduta e Boas Práticas de Manejo foram elaborados e implantados (BOYD, 2003). Embora se veja muito mais retórica do que ações concretas, atualmente a aquicultura é mais responsável do que foi há anos atrás (VALENTI, 2010). No entanto, ainda são escassos os mecanismos para avaliar a sustentabilidade da aquicultura. Neste contexto, vale destacar os trabalhos que utilizaram e testaram indicadores de sustentabilidade para avaliar a aquicultura, tais como os desenvolvidos por DALSGAARD et al.(1995), DALSGAARD \& OFICIAL (1997), GONZÁLEZ et al. (2003), BOYD et al. (2007), PULLIN et al. (2007), TIPRAQSA et al. (2007), BERGQUIST (2007) e EVAD (2008).

Entre 1987 e 1996, a aquicultura cresceu 50\% em nível mundial e 264\% na China, principal produtor (NEW, 1999). Com crescimento ininterrupto, houve aumentoprogressivo da quantidade de espécies cultivadas, da área em produção e do crescimento tecnológico do setor, gerando credibilidade e oportunidade de investimento. Em 2000 a produção da aquicultura mundial era de 35,5 milhões de toneladas, chegando a 45,5 milhões de toneladas em 2004, um aumento de mais de $28 \%$, e com estimativas de crescimento superior a $5 \%$ para o ano seguinte, enquanto que a produção mundial por captura teve decréscimo de 0,6\% entre o ano de 2000 e 2004, com estimativas de redução acima de 1\% (FAO, 2007). A piscicultura ainda

\footnotetext{
${ }^{26}$ Engenheiro de Pesca, Doutor em Ciência Animal. Departamento de Engenharia de Pesca da Universidade Federal de Rondônia. yuri.andrade@unir.br
} 
detém a maior produção dentre estas categorias com participação de $67,1 \%$ da produção total. Outras modalidades de produção aquática menos expressiva são realizadas, como o cultivo de algas, mas em menor escala (SCORVO FILHO, 2004).

A produção mundial da aquicultura em 2004 foi de 59 milhões de toneladas, com uma geração de renda de aproximadamente US\$70,3 bilhões. A china foi líder na produção com $70 \%$ (41,3 milhões de toneladas) do total $51 \%$ (US $\$ 36$ bilhões) da geração de receitas (FAO, 2006). No período de 1998 a 2008 a aquicultura deteve um crescimento de $42,94 \%$ sendo responsável por uma produção de 68.348 .943 de toneladas em 2008 (ABCC, 2010).

\section{Aquicultura Brasileira}

O Brasil é um país de dimensões continentais, sendo o quinto maior país do mundo ocupando $1,7 \%$ do território do globo terrestre e $47 \%$ da América do Sul. Possui uma área de $8.514 .876,599 \mathrm{~km}^{2}, 7.367 \mathrm{~km}$ de costa oceânica, 3,5 milhões de $\mathrm{km}$ quadrado de ZEE e uma população estimada em 184 milhões de habitante, portanto, possui um imenso mercado consumidor em potencial para produtos provenientes da aquicultura (OSTRENSKY et al. 2000).

O Brasil é apontado pela FAO (2007), como um dos países do mundo que apresenta maior crescimento em termos de aquicultura. Enquanto a média internacional de produtividade é de $958 \mathrm{~kg} / \mathrm{ha} / \mathrm{ano}$, no Brasil a produtividade cresceu de $1.015 \mathrm{~kg} / \mathrm{ha} /$ ano em 1997 para $6.084 \mathrm{~kg} / \mathrm{ha} / \mathrm{ano}$ em 2003 em decorrência da carcinicultura, sendo a região Nordeste responsável por $95,2 \%$ da produção nacional de camarão (FAO, 2003). No Nordeste do Brasil, embora as fazendas de cultivo de camarão tenham se instalado desde 1980 , foi somente a partir de 1995 , com a introdução do camarão marinho Litopenaeus vannamei, que esta indústria experimentou um rápido crescimento.

A produção aquícola brasileira tem crescido acima da média mundial desde 1995. Mesmo com um crescimento negativo da ordem de $1,4 \%$ entre os anos de 2003 e 2004, a aquicultura brasileira cresceu em média $21,1 \%$ /ano enquanto que a mundial cresceu cerca de 9,5\%/ano, no período de 1991 e 2004. A queda da produção da aquicultura no período de 2003 e 2004 foi provocada pela redução na produção da carcinicultura em 15,8 \% (FAO, 2007). Segundo a Associação Brasileira dos Criadores de Camarão - ABCC, 2010, no período de 2003 a2008 a aquicultura brasileira deteve um crescimento de $6,19 \%$ sendo responsável por uma produção de 290.195 toneladas em 2008, em se tratando somente da aquicultura continental, 
essa teve um crescimento no mesmo período de $23 \%$ (ABCC, 2010). O Ministério da Pesca e Aquicultura - MPA, 2010, estimou a produção aquícola brasileira de 2009 em 415.649 toneladas e prevê para 2011 uma produção estimada de 570.000 toneladas.

Progressivamente, o Brasil vem ganhando posições no ranking internacional estabelecido pela FAO. Em 1994, era $32^{\circ}$ em produção aquícola e o $26^{\circ}$ em termos de valores. Em 2004 o Brasil ocupava o $18^{\circ}$ lugar no ranking mundial de produção aquícola com $0,5 \%$ da produção mundial e $12^{\circ}$ em termos de receitas geradas com $1,4 \%$ do total (FAO, 2006). Dados mais recentes apontam o Brasil em $12^{\circ}$ lugar no ranking dos maiores produtores aquícolas (ABCC, 2010).

No Brasil, a atividade cresceu 43,8\% entre 2007 e 2009, passando de 289 para 425 mil toneladas (MPA, 2010). O Plano de Desenvolvimento "Mais Pesca e Aquicultura - 2008/2011", lançado em 2008 pela Secretaria Especial da Aquicultura e Pesca, atual Ministério da Pesca e Aquicultura, possui como principais metas a demarcação de 40 reservatórios de águas da União para criação de pescado, implantação dos Planos Locais de Desenvolvimento da Maricultura (PLDM) em 13 estados e financiamento para 27.000 famílias visando melhorar a infra-estrutura, com a implantação de 11.250 ha de viveiros em estabelecimentos rurais de pequeno porte. Durante décadas, a produção pesqueira no Brasil não recebeu a devida atenção do governo, o que refletiu na produção, que permaneceu estagnada por um bom período. Com a criação da SEAP e a adoção de uma série de medidas, o setor passou a responder a esses estímulos e mais acentuadamente a partir de 2007, com a consolidação das políticas públicas. O Nordeste, de acordo com os dados de 2009, é a maior região produtora de pescado do Brasil com 411 mil toneladas/ano, seguida da região Sul, com 316 mil/ano. A região Norte está em terceiro lugar, com 263 mil toneladas, a Sudeste, com 177 mil e, por último, Centro-oeste, com 72 mil. Santa Catarina é o maior produtor entre os estados, com 207 mil toneladas/ano, seguida do Pará, com 136 mil toneladas. A Bahia, com 119 mil toneladas, é o terceiro maior produtor nacional seguida de perto pelo Ceará, com 88 mil toneladas.

No entanto, para que os avanços sejam duradouros, é necessário adotar os preceitos da aquicultura sustentável, pois uma produção que considera apenas o mercado e as oportunidades financeiras leva a sistemas que não se sustentam ao longo do tempo (VALENTI et al 2010). 


\section{Monocultivo de camarão}

A carcinicultura teve início na década de 30, no Japão, com o Dr. Motosaku Fujinaga, onde trabalhando com a espécie Marsupenaeus japonicus em condições controladas, obteve a desova desses animais, iniciando assim os primeiros trabalhos de larvicultura (ROSENBERRY, 1992; NUNES et al 2004).

No Brasil, a carcinicultura marinha teve seu início na década de 70, no entanto só assumiu nível industrial na década de $80 \mathrm{com}$ uma produção fundamentada no cultivo do camarão Penaeus japonicus. Mas, devido à falta de estudos que contribuíssem para tornar esse cultivo economicamente viável no país e a dificuldade de adaptação desta espécie a baixas salinidades, seu cultivo não foi um sucesso, sendo substituída por espécies nativas como: Litopenaeus subtilis; Litopenaeu schimitti; Farfantepenaeus brasiliensis e Farfantepenaeus paulensis ou por outras espécies exóticas, entre elas o Litopenaeus vannamei (MAIA, 2005). Mas, somente a partir de 1994, é que a carcinicultura passou a obter resultados realmente satisfatórios, passando de uma atividade de risco para uma oportunidade de investimento altamente atrativa economicamente. Isto resultou em arrojados investimentos no setor, o que proporcionou o rápido crescimento territorial da área cultivada de camarões e maior profissionalismo, caracterizando a terceira e atual fase de desenvolvimento (NUNES, 2001; GESTEIRA et al 2006).

A aquicultura brasileira é baseada principalmente em regimes semi-intensivos de produção e, com exceção do setor da carcinicultura, é sustentada principalmente por pequenos produtores. Longe de ser um problema, esse fato pode ser encarado como positivo, posto que na maioria dos casos, os grandes produtores mundiais de organismos aquáticos cultivados são países cuja produção está baseada nas pequenas propriedades (VALENTI et al 2000).

Como exemplo de produção semi-intensivo em sistema de monocultivo, enquadram-se os cultivos de camarões, que empregam uma tecnologia relativamente bem desenvolvida de produção, envolvendo: o uso de tanquesberçário, de ração comercial, de aeradores e controle da qualidade da água. Tal regime fez com que a produtividade média dos cultivos de camarões marinhos chegasse a $4.510 \mathrm{~kg} /$ hectare, em 2004 (ABCC, 2006). 
A introdução do camarão ( $L$. vannamei), uma espécie marinha que apresenta tolerância a águas com baixas concentrações de sais (VALENÇA, MENDES, 2004), possibilitou o cultivo de camarões em águas interiores, com a intensificação dessa atividade no nordeste do Brasil. Com condições ambientais favoráveis, mudança no sistema de cultivo, introdução da espécie exótica L. vannamei, a carcinicultura começou a se expandir, tendo como características marcantes 0 aumento considerável de laboratórios para produção de pós-larvas, aumento da quantidade de fábricas de rações especializadas para $L$. vannamei, utilização de técnicas modernas e mais eficientes. Esse crescimento elevou a atividade a um lugar de destaque no mercado nacional e impulsionou os produtores a investirem no mercado externo como alternativa para o escoamento da produção (NUNES, 2001; OSTRENSKY, 2002).

No entanto, o confinamento dos animais aliado às densidades populacionais elevadas, pode criar situações de estresse que propiciam o aparecimento de doenças e favorecimento de uma rápida transmissão de patógenos veiculados pela água, resultando em problemas de crescimento, sobrevivência e conversão alimentar. Com exceção dos vírus WSSV e YHV, tinham sido registradas todas as outras enfermidades virais de camarões no Brasil, havendo ainda, na Região Nordeste, a ocorrência de uma doença espécie-específica denominada Vírus da Mionecrose Infecciosa Muscular (IMNV), em fazendas de engorda de L. vannamei (NUNES et al. 2004). Além disso, outros fatores como a valorização da moeda brasileira; a dificuldade de novos licenciamentos devido aos conflitos ambientais da atividade e a dificuldade para obtenção de novos financiamentos, já que a mesma se tornara uma atividade de risco (RIECHE, MORAES, 2006), concorreram para ampliar as dificuldades enfrentadas pelos produtores.

Através do ultimo censo divulgado pela Associação Brasileira de Criadores de Camarões $(A B C C)$, o Brasil possui aproximadamente 1.000 produtores contando com mais de 16.500 ha de espelho d'água e uma produção de 65.000 toneladas em 2007, sendo o ano de 2003 como o ano do maior pico de produção, 90.190 toneladas (ABCC, 2008). Foi registrada, no ano de 2009, a mesma produção de 2007 , sendo que, $76,13 \%$ da produção neste ano (2007) foram comercializadas no mercado interno e, em 2009, 91,19\% sendo a área de espelho d'água utilizada para produção de 19.715 há (ABCC, 2010). Apesar de o país dispor de condições climáticas, hidrobiológicas e topográficas favoráveis em toda a extensão de sua costa, o desenvolvimento da carcinicultura marinha está concentrado na região Nordeste (ROCHA, 2005).

Segundo Sampaio, Couto (2003), a carcinicultura geraria 1,89 empregos diretos e 1,86 empregos indiretos por hectare, totalizando 3,75 empregos por hectare, ou o equivalente a cerca de 50.000 empregos, sobretudo no Nordeste. De 
acordo com Sampaio, Couto (2003), $88 \%$ do trabalho ofertado pela carcinicultura é ocupado por mão-de-obra sem qualificação profissional e $14 \%$ das oportunidades por mão-de-obra feminina.

\section{Principais características dos sistemas de produção}

Podemos destacar três tipos de sistemas de cultivo adotados para engorda do camarão da Malásia: o sistema extensivo, o semi-intensivo e o intensivo, diferenciados, basicamente, em função do manejo utilizado (VALENTE, 1998).

- Sistema extensivo

O cultivo é realizado em represas com baixa densidade de estocagem, com até dois indivíduos por metro quadrado (2ind. $/ \mathrm{m}^{2}$ ). Neste caso, não são praticados o monitoramento da qualidade de água, arraçoamento e a adubação da água, e não se faz o controle de produção. A produtividade gira em torno de $300 \mathrm{~kg} / \mathrm{ha} / \mathrm{ano}$.

- Sistema semi-intensivo

Neste tipo de sistema o cultivo é realizado em viveiros escavados no solo, que variam de 1.0 a $5.0 \mathrm{~m}^{2}$, utilizando uma densidade de até $10 \mathrm{ind} . / \mathrm{m}^{2}$, com controle de qualidade de água, oferta de rações específicas para o camarão, realização de biometrias, despescas seletivas e totais e controle de produção, podendo a produtividade atingir de 1.200 a $1.800 \mathrm{~kg} / \mathrm{ha} / \mathrm{ano}$.

- Sistema Intensivo

Caracteriza-se por apresentar um rigoroso controle de produção e qualidade de água, utilização de rações balanceadas, densidade acima de $10 \mathrm{ind} . / \mathrm{m}^{2}$, emprego de tecnologia de ponta, com utilização principalmente de aeradores e a produtividade esperada é superior a $3.0 \mathrm{~kg} / \mathrm{ha} / \mathrm{ano}$.

Para os cultivos semi-intensivo e intensivo existem dois métodos de criação em função do crescimento não uniforme, característico desses camarões: o tradicional e o contínuo.

Método Tradicional: o povoamento é realizado com pós-larvas, e, a partir do $4^{\circ}$ ou $5^{\circ}$ mês de engorda iniciam-se as despescas seletivas encerrando-se ao término do $6^{\circ}$ ou $7^{\circ}$ mês com a despesca total (final). O viveiro é totalmente drenado e reabastecido, iniciando-se um novo cultivo, a segunda safra. Em geral, recomenda- 
se uma manutenção dos viveiros a cada duas safras, conforme será descrito posteriormente. É o método de cultivo mais recomendado.

Método Contínuo: O viveiro não é drenado a cada despesca final, permanecendo alagado por dois ou três anos. Com cerca de 5 meses de cultivo fazse a primeira despesca parcial, utilizando-se uma rede seletiva para capturar apenas os camarões de peso comercial. Este procedimento é repetido diversas vezes, a cada 20/30 dias, sempre seguido de novos povoamentos.

\section{Principais espécies cultivadas no brasil}

De acordo com associação brasileira dos criadores de camarão (ABCC,2014), as espécies de maior significância no cultivo nacional, ou seja, de importância econômica para atividade encontra-se em três espécies, são elas: Litopenaeus vannamei (Figura 1); Macrobrachium rosenbergii (Figura 2) e Macrobrachium amazonicus (Figura 3).

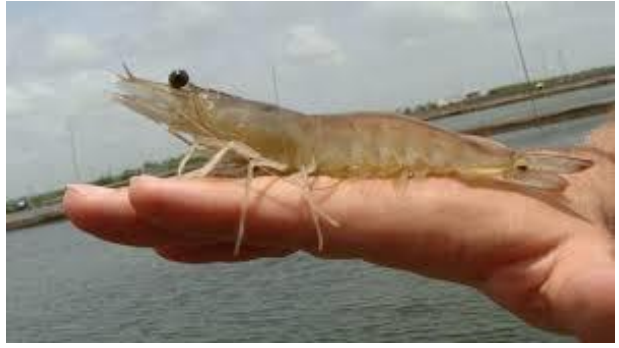

Figura 1. Litopenaeus vannamei

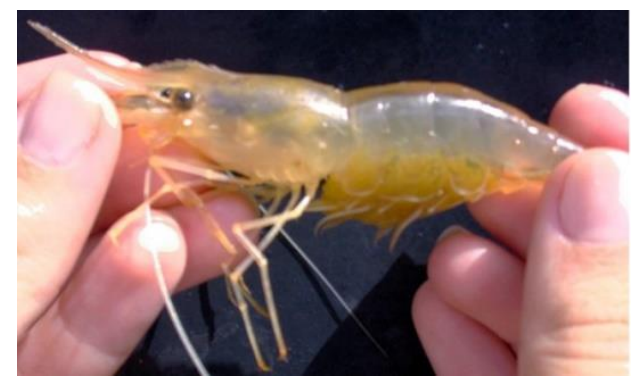

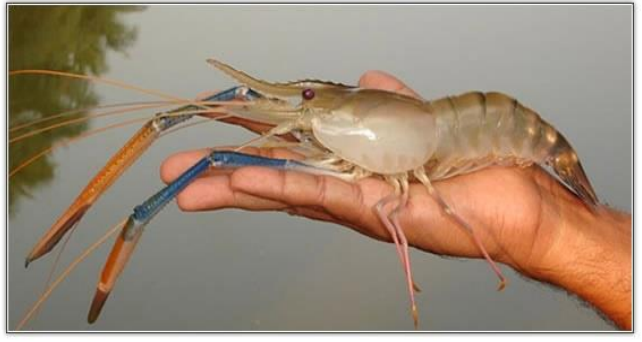

Figura 2. Macrobrachium rosenbergii

Figura 3. Macrobrachium amazonicus 


\section{Considerações finais}

Levando em conta a capacidade de avanço tecnológico e de interesse em diversas esferas econômicas, o estado de Rondônia apresenta características favoráveis para o cultivo de diversas espécies de camarão, entre elas, o camarão nativo da região o Macrobrachium amazonicus (camarão canela).

Entretanto, a falta de pesquisas e a conclusão de um pacote tecnológico de produção desta espécie, favorece o interesse no cultivo de espécies exóticas, como exemplo o camarão marinho Litopenaeus vannamei e o de água doce Macrobrachium rosenbergii, espécies que possuem boa capacidade de crescimento em água doce e pacote de informações de cultivo bem definidos.

\section{Referências}

ASSOCIAÇÃO BRASILEIRA DE CRIADORES DE CAMARÃO-ABCC 2004 O agronegócio do camarão marinho no Brasil em 2003. 11p. (mimeografado).

BASCARDIN BORGHETTI, N.R.; OSTRENSHY, A.; BORGHETTI, J.R. 2003 Aqüicultura Brasileira. 129p.

CAVALCANTI, L. B.; CORREIA, E. S.; CORDEIRO, E. A. Camarão: manual de cultivo do Macrobrachium rosenbergii (Pitu havaiano - gigante da Malásia). Recife: AQUACONSULT, 1986. 143p.

FAVARETTO, L.; BOGDAN, A., SANTOS, E. S. Consumo de oxigênio em Macrobrachium amazonicum (Heller, 1862). Efeito da saturação de oxigênio dissolvido. Acta Amazônica, v.6,n.4,p.449-453.1976.

FOOD AND AGRICULTURE ORGANIZATION-FAO 2002 World Fisheries production by capture and aquaculture, by country. http://www.fao.org/fi/statis/summ-99/aquaa.0.pdf.

LIMA, J.S.G.; ODINETZ-COLLART, O. Ecologia do camarão Macrobrachium amazonicum (Decapoda, Palaemonidae) no açude Poço de Cruz (Ibirimim). In: CONGRESSO BRASILEIRO DE ENGENHARIA DE PESCA , 10.1997. GUARAPARI. Anais..., Gurarapari: Associação dos engenheiros de Pesca do Espírito Santo, 1997. Cd room, p.378-384. Guararapari, 1997. 
LOMBARDI, J. V.; LOBÃO, V. L. Receitas culinárias com o camarão gigante da Malásia. Boletim Técnico do Instituto de Pesca, São Paulo, v. 1, n. 5, p. 15, março, 1992.

NEW, M. B. Freshwater prawn culture: a review. Aquaculture, v.8, n.3-4, p.99-143, 1990.

PINHEIRO, M. A. A., HEBLING, N. J. Biologia de Macrobracium rosimberguii (De Man, 1879). In: VALENTI, W. C. Carcinicultura de água doce. Tecnologia para produção de camarões. Brasília: Instituto Brasileiro de Meio Ambiente e dos Recursos Naturais Renováveis. 1998. p. 21-46.

SEBRAE, ESTUDOS DE MERCADO, aquicultura e pesca: CAMARÕES. SETEMBRO DE 2008.

SILVA, M.C.N.; FRÉDOU, F.L.; FILHO, J.S.R. 2007. Estudo do crescimento do camarão Macrobrachium amazonicum (HELLER, 1862) da ilha de Combú, Belém, Pará. Amazônia: Cia. \& Desenvolvimento, v. 2, Belém, n. 4, jan./jun.

VALENTI, W.C. 1984. Estudo populacional dos camarões de água doce Macrobrachium acanthurus (Wiegman, 1836) e Macrobrachium carcinus (Linnaeus, 1785) do rio Ribeira de lguape (Crustacea, Palaemonidae). São Paulo. 149 p. (Dissertação de Mestrado. Universidade de São Paulo).

VALENTI, W. C. (Ed.). Carcinicultura de água doce: tecnologia para produção de camarões. IBAMA/FAPESP, 1998. 383 p.

VALENTI, W.C. 1996. Criação de camarões em águas interiores. Jaboticabal: FUNEP, 81 p. (Boletim Técnico, n. 2).

VALENTI, W.C. 2008. A aqüicultura brasileira é sustentável?. Aqüicultura \& Pesca. v.34: p.36-44. 


\title{
Desmistificando o desenvolvimento sustentável
}

\author{
Maximiliano Barroso Bonfá 27
}

\section{Introdução}

A aproximadamente três décadas os termos "Desenvolvimento Sustentável" e "Sustentabilidade" foram cunhados e ganharam o status de palavras de ordem junto a comunidade internacional. Isto se deu após a publicação em 1987 do relatório da Comissão Mundial sobre Meio Ambiente e Desenvolvimento (WCED), intitulado Nosso Futuro Comum em inglês "Our Common Future".

Desde então, várias iniciativas estão sendo adotadas, sejam elas na esfera local, nacional ou internacional. Estas iniciativas são tentativas de abordar os diferentes desafios dos aspectos ambientais. Porém alguns anos antes, ainda na década de 1960, Raquel Carson lançou o livro Primavera Silenciosa (Silent Spring). Tal livro foi considerado um marco na compreensão das interconexões entre o meio ambiente, a economia e as questões relativas ao bem-estar social (NASCIMENTO, LEMOS, MELLO, 2008). O trabalho de Carson, neste momento, trouxe para a mesa de debates os primeiros indícios do surgimento de um novo conceito, o de desenvolvimento sustentável.

Partindo destas ideias não é preciso uma investigação detalhada para se dar conta do contrassenso no qual o findar do século $X X$ e o inicio do século $X X I$ se apoia. De um lado existem, o crescimento econômico e a transformação tecnológica sem precedentes, por outro, a dramática condição social de inúmeras pessoas, além de problemas ambientais assustadores. No decorrer dos últimos anos desenvolveuse um aparato científico-tecnológico capaz de resolver grande parte dos principais problemas ecológicos, contudo isso não foi capaz de resolver a incapacidade das formas sociais organizadas de se apropriarem desses meios (VECCHIATTI, 2004).

\footnotetext{
27 Administrador. Mestrando do Programa de Pós Graduação em Administração da Universidade Federal de Rondônia. Docente da Faculdade de Ciências Biomédicas de Cacoal e SENAI. 
Contudo ao se observar o entendimento dos cidadãos sobre o conceito de desenvolvimento sustentável, pode-se observar que algumas pessoas ainda não conhecem plenamente o conceito. Segundo Teixeira (2005) a ideia de desenvolvimento sustentável que foi instituída como solução para o dilema entre desenvolvimento socioeconômico e conservação ambiental, apresenta problemas relacionados ao próprio conceito de sustentabilidade.

Já para Torresi, Pardini e Ferreira (2010, p. 01) "a percepção da maioria das pessoas é que a sustentabilidade está relacionada apenas às emissões de gases para a atmosfera como, por exemplo, o gás carbônico, e que este é o único risco a que o planeta está exposto." Estes mesmos autores ainda alegam que o desenvolvimento sustentável não pode s restringir a apenas uma ação, como reduzir as emissões de gases que causam o efeito estufa.

Neste sentido pode-se ainda observar que Holmberg considera que o desenvolvimento sustentável como um conceito se tornou desvalorizado ao ponto em que, para alguns, tornou-se agora apenas um clichê. Este fato demonstra que o Termo ainda necessitava de grande debate e apresentava-se ainda indefinido (MEBRATU, 1998).

Neste texto serão tratados os conceitos e seguintes tópicos relacionados a Desenvolvimento sustentável:

- O Paralelo Ecológico e o Desenvolvimento Sustentável

- A Evolução Histórica do Conceito de Desenvolvimento Sustentável

- O Conceito

- Falhas Transversais

\section{O Paralelo ecológico e o desenvolvimento sustentável}

Somente em meados do século XX, o ser humano pôde observar o planeta do espaço pela primeira vez. Observada do espaço, a Terra é uma bola frágil e pequena, dominada não pela ação e pela obra do homem, mas por um conjunto ordenado de nuvens, oceanos, vegetação e solos. O fato de a humanidade ser incapaz de agir conforme essa ordenação natural está alterando fundamentalmente os sistemas planetários. Muitas dessas alterações acarretam ameaças à vida (WCED, 1991) 
Desta forma para entender como o ser humano vem atuando para alterar esta ordenação natural é necessário recuar no tempo cerca de 8.000 anos, quando a população humana chegou ao numero de cerca de 10 milhões de pessoas que viviam como nômades. Quando neste instante para se adaptar ao problema da escassez de recursos silvestres que emergiu graças a superpopulação existente, estes adotaram duas formas de combater o problema. Uma destas formas foi intensificar seu estilo de vida migratório, a outra consistia em migrar de suas regiões de origem na África e do Oriente Médio para o resto planeta (MEBRATU, 1998)

Neste mesmo intento alguns dos nômades passaram a domesticar animais e cultivar plantas, criando assim a primeira concepção de agricultura. Isso ocorreu por volta do ano de 3.000 a.c. ou mais precisamente no período Neolítico (RAVEN et. al, 2001) Como resultado dessa mudança no comportamento humano, iniciou-se um verdadeiro avanço em relação ao desenvolvimento de uma agricultura mais evoluída, sobre tudo apoiada na inovação e na tecnologia.

No entanto, a agricultura foi uma resposta bem sucedida à escassez de animais selvagens enfrentada pela sociedade nômade, o que permitiu a população continuar o crescimento populacional, que partiu de cerca de 10 milhões de pessoas para aproximadamente 800 milhões em 1750 (MEADOWS et al 1992, apud MEBRATU, 1998)

Neste momento a agricultura cede espaço para a revolução industrial fez com que grande numero de arvores fossem destruídas para que as caldeiras fossem alimentadas com lenha ou carvão. Também foi necessária uma maior concentração de trabalho em torno das minas e fábricas, e exigiu a elevação da ciência e tecnologia para posições de destaque na sociedade humana. O sucesso da transformação industrial, também levou a humanidade à escassez ecológica (MEBRATU, 1998). Sendo que após a Revolução Industrial a atuação humana sobre o meio ambiente ficou mais agressiva (FOGLIATTI et al, 2008 apud FERREIRA, 2013).

Durante a maior parte da história humana, o crescimento da população, a degradação e o esgotamento dos recursos, a reestruturação da sociedade, e o desenvolvimento de novas tecnologias em geral têm sido tão lentos que foram imperceptíveis. No entanto, durante os últimos dois séculos, a economia mundial tem mostrado um crescimento incrível, transformando o caráter do planeta e, especialmente, da vida humana. A industrialização e a globalização alteraram o padrão de vida no mundo desenvolvido, que saiu da subsistência à riqueza, ao passo que o maioria das pessoas no mundo em desenvolvimento ainda são submetidos a miséria. (MEBRATU, 1998) O progresso tecnológico alcançado pela humanidade no século passado foi superior a todo o progresso do homem ao longo da sua história. Neste aspecto, paradoxalmente, cada avanço dado no campo da ciência resultou 
também, de algum modo, em agressões ao meio ambiente. (FOGLIATTI et al, 2008 apud FERREIRA, 2013).

\section{A evolução histórica do conceito de desenvolvimento sustentável}

O marco inicial da discussão sobre o desenvolvimento sustentável ocorreu há pouco mais de vinte anos, com a publicação em 1987 do relatório da Comissão Mundial sobre Meio Ambiente e Desenvolvimento (CMMAD), conhecida como Comissão Brundtland. (BARBIERI et al 2010)

Este relatório constituiu um importante ponto de viragem política para o conceito de desenvolvimento sustentável. Mas isso não é nem o ponto de partida nem o eventual final do processo de desenvolvimento do conceito. Neste intento a discussão que segue será dividida em três períodos históricos: Pré-Estocolmo, cobrindo o período até a Conferência sobre Meio Ambiente e Desenvolvimento de Estocolmo (1972); de Estocolmo a Conferência das Nações Unidas sobre Meio Ambiente e Desenvolvimento - UNCED (1972-1992); e Pós-UNCED (1992 em diante).

\section{Pré-Estocolmo}

Historicamente, as religiões nos ensinam a perceber e agir sobre a natureza não humana. No entanto, ao mesmo tempo, "a religião também representou a voz da natureza para a humanidade". Os ensinamentos espirituais têm celebrado e consagrado os nossos laços com o mundo não humano, lembrando-nos da nossa parceria delicada e inevitável com o ar, terra, água e outros seres vivos. Para avaliar a visão de religião da natureza e ver como a teologia contemporânea lida com a crise ambiental, deve-se verificar com cuidado a plena variedade de escritos e práticas que as tradições religiosas oferecem (MEBRATU, 1998)

Além das religiões dominantes do Oriente e do Ocidente, temos numerosas crenças e tradições indígenas que foram usadas como base para os mecanismos de enfrentamento tradicionais muito antes do surgimento de qualquer das crenças religiosas. No pensamento havaiano, há paralelos estreitos entre os seres humanos e natureza. Os havaianos tradicionalmente veem o mundo como um ente vivo (MEBRATU, 1998) 
Neste sentido seja qual for o problema ambiental, não encontraremos nos ensinamentos das crenças religiosas, de leste a oeste, ou nas tradições indígenas uma base para enfrentar a crise ambiental dos dias autuais. No entanto, a sabedoria tradicional tem muito a oferecer em termos de vida em harmonia com a natureza e na sociedade; sendo este um dos princípios fundamentais do conceito da sustentabilidade (MEBRATU, 1998)

Thomas Robert Malthus (1766-1834) é considerado o primeiro economista a prever os limites para crescimento causado pela escassez de recursos. Segundo a teoria de Malthus, a população aumenta geometricamente, enquanto os aumentos de subsistência ocorrem aritmeticamente na melhor das hipóteses, criando assim o "Limite de escassez absoluta" (MEBRATU, 1998)

Neste contexto em 1968, um grupo de pessoas de vários países, composto por educadores, cientistas, economistas, humanistas, industriais e funcionários públicos, se reuniram para discutir as problemáticas mais recentes vividas pela humanidade, e as suas repercussões sobre a vida das pessoas (Meadows et al 1972).

Nascia ali o "Clube de Roma", uma organização informal que tinha como objetivo promover o entendimento dos componentes: econômicos, políticos, naturais e sociais que compõem o sistema global da nossa sociedade. Tinham como objetivo principal estudar o complexo de problemas que atingiam várias nações: pobreza, degradação ambiental, expansão urbana sem controle etc. O Clube de Roma produzia relatórios que expressavam uma visão neomalthusiana obtendo grande impacto sobre a sociedade da época e com isso colocaram a discussão sobre desenvolvimento e os seus impactos, no centro das discussões (Barbieri, 2004).

Se observar ainda a história da economia política, se encontrará a tradição que poderíamos chamar de anarquismo. A tradição, enquanto intimamente associada com os valores socialistas, no entanto, prefere misturar-se aos sistemas de economia "puras". Um despertar mundial para o espectro da poluição global, esgotamento de recursos, concentração corporativa, e a diminuição correspondente de liberdades individual, o livro de Schumacher - Small is Beautiful, 1979 - foi "um raio de esperança" (MEBRATU, 1998)

Embora o livro contenha um número de ideias controversas e discutíveis, a preocupação de Schumacher sobre a exaustão de recursos do planeta deu novo impulso a toda uma geração de defensores do meio ambiente, enquanto o seu esforço de olhar para o desenvolvimento econômico, aspectos ecológicos e sociais de um determinado sistema acrescentou uma nova dimensão ao o discurso sobre a "escala da organização." (MEBRATU, 1998) 
Alguns especialistas acreditam que o conceito apropriado de tecnologia e as necessidades sociais prementes são o precursor imediato para o conceito de Desenvolvimento Sustentável.

\section{Pós Estocolmo}

A Conferência das Nações Unidas sobre o Meio Ambiente Humano, realizada em Estocolmo, Suécia, em 1972, reuniu a comunidade internacional para discutir o meio ambiente global e as necessidades de desenvolvimento e que produziu um documento que sinalizava a necessidade de se criar um processo de gestão planetária dos problemas ambientais que culminou, logo após, na criação do Programa das Nações Unidas para o Meio Ambiente - PNUMA. Esta conferencia representou um grande passo a frente no desenvolvimento do conceito de sustentabilidade desenvolvimento sustentável, pois havia indícios de que a forma de desenvolvimento econômico teria de ser alterada (GALLO et al 2012)

O tema foi levantado alguns anos mais tarde pela Comissão Mundial sobre Meio Ambiente e Desenvolvimento (WCED), também conhecida como Comissão Brundtland, no relatório intitulado Nosso Futuro Comum, que detém a declaração chave e pioneira do desenvolvimento sustentável, que definiu como "o desenvolvimento que satisfaz as necessidades do presente sem comprometer a capacidade das gerações futuras de suprir suas próprias necessidades". Desde publicação deste relatório, o desenvolvimento sustentável tornou-se cada vez mais o elemento central do discurso ambiental, levando a uma ampla aceitação com diversas interpretações (FERREIRA, 2013)

O Relatório Brundtland é considerado um marco no processo de debate sobre a interligação entre as questões ambientais e o desenvolvimento, pois ele faz um alerta para a necessidade de as nações unirem-se na busca de alternativas para os rumos vigentes do desenvolvimento, a fim de evitar a degradação em nível planetário (NASCIMENTO, LEMOS, MELLO, 2008). 


\section{Pós Rio-92}

No Relatório Brundtland foi definido o conceito de Desenvolvimento Sustentável, contudo esse conceito, que foi desenvolvido no final da década de 1980, só ganhou força a partir da Conferência Mundial de Desenvolvimento e Meio Ambiente (UNCED), realizada no Rio de Janeiro, em 1992, que também ficou conhecida como a "Conferência do Rio", ou a "Cúpula da Terra". UNCED levou à produção dos seguintes documentos internacionais: Declaração do Rio; Agenda 21; e as convenções sobre a desertificação, biodiversidade, e mudanças climáticas. . (NASCIMENTO, LEMOS, MELLO, 2008)

Apesar do relativo sucesso da UNCED, esta trouxe ao debate acadêmico uma certa confusão sobre a utilização do termo Desenvolvimento sustentável, tanto que para Holmberg (1994) "o desenvolvimento sustentável como um conceito se tornou desvalorização ao ponto em que, para alguns, é agora apenas um clichê". Este fato demonstra que o Termo ainda necessitava de grande debate e apresentava-se ainda indefinido (MEBRATU, 1998).

Ainda neste contexto o conceito de desenvolvimento sustentável "alcançou um destaque inusitado a partir da década de 1990, tornando-se um dos termos mais utilizados para se definir um novo modelo de desenvolvimento" (BELLEN, 2004, pág. 01).

\section{O conceito}

Apesar da gama de posições dentro do debate, nos anos seguintes a Conferência de Estocolmo 1972, o consenso científico sobre a ocorrência de desequilíbrios ecológicos graduais, chega-se à conclusão de que o dano infligido por atividades humanas sobre $\mathrm{o}$ ambiente natural tornar essas atividades insustentáveis (EKINS, JACOBS, 1995 apud MEBRATU, 1998). Isto criou a necessidade de uma nova visão de mundo para servir como base para um consenso global, o que eventualmente levou à cunhagem do termo "desenvolvimento sustentável".

Em termos gerais, a variedade existente de definições de desenvolvimento sustentável podem ser categorizados em três grupos principais. Estes são: (1) a Versão Institucional, (2) a versão ideológica, e (3) a versão acadêmica. Todas essas definições são baseadas em aceitação de que o mundo se depara com uma crise ambiental, e que é preciso fazer uma mudança fundamental afim de superar a crise. 


\section{Falhas transversais}

A maioria da literatura referente a sustentabilidade e desenvolvimento sustentável concorda com a limitação de pensamento reducionista, científico em compreender e lidar com a crise ambiental. As tendências existentes apontam ao desenvolvimento de um "polaridade entre a visão reducionista e a visão holística" (Mebratu 1996). Neste aspecto os reducionistas tendem a observar o detalhe para posteriormente alcançar o todo da questão, visto que os holísticos abordam os problemas de forma totalmente inversa.

Figura 1. O Modelo Dominante

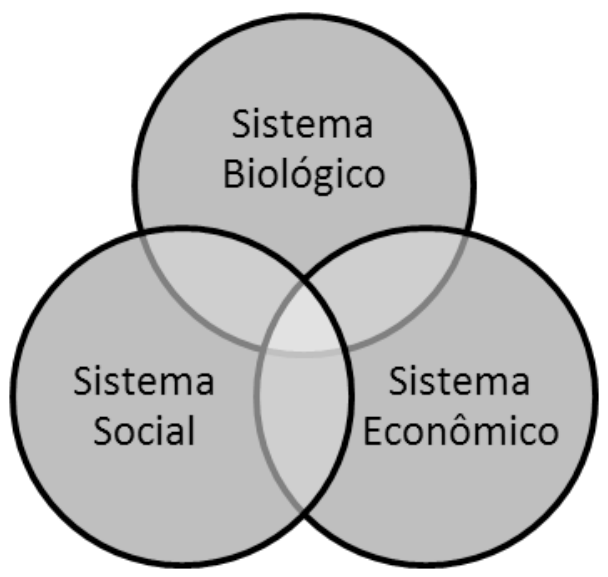

Fonte: Adaptado de Mebratu, 1998.

O entendimento geralmente aceito do mundo cósmico com relação ao o debate ambiental e do conceito de sustentabilidade baseia-se no reconhecimento da existência supostamente separados de sistema natural, sistema econômico, e do sistema social (Figura 1). Este modelo sugere que a atividade corporativa orientada pela lógica do desenvolvimento sustentável é aquela que, ao mesmo tempo, proporciona lucros, é socialmente justa e ambientalmente correta. Esse modelo ficou conhecido como o tripé do desenvolvimento sustentável (FERREIRA, 2013).

Ao contrário do modelo acima descrito, as seguintes conclusões podem ser retiradas do Modelo Interdependência Cosmica desenvolvido com base na redução holística (MEBRATU 1996). Neste modelo: (Figura 2) O universo humano, em geral, e do cosmos econômicos e sociais, em particular, nunca foi, e nunca será, um sistema separado independente do universo natural; As crises ambientais registradas em toda a história humana são um resultado do efeito cumulativo. 
Figura 2. A Interdependência Cósmica

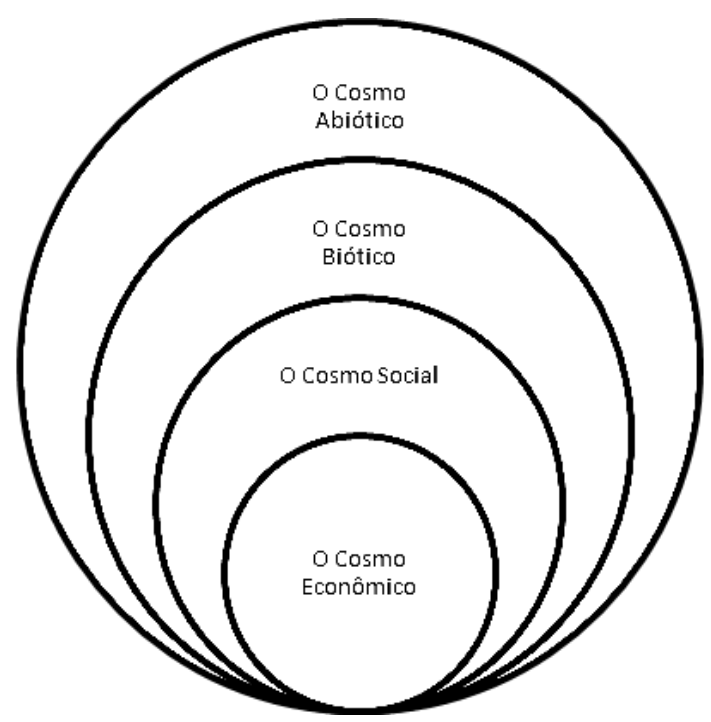

Fonte: Adaptado de Mebratu, 1998.

A outra grande falha conceitual que está se tornando uma fonte de confusão em o debate ambiental é a concepção do termo "meio ambiente". Há dois problemas básicos que surgem a partir deste equívoco. Principalmente, ambiente e ecologia tornaram-se cada vez mais sinônimo, limitando o foco do ambiente para o ambiente natural. Em segundo lugar, existe um perigo de abstração, devido à noção distendida da palavra "ambiente" (MEBRATU, 1998)

De acordo com o Dicionário Webster,ambiente é definido como: "o conjunto de coisas que as rodeia, condições, ou influências; arredores, ambiente; o ar, a água, os minerais, os organismos e todos os outros fatores externos que cercam e afetam um determinado organismo em qualquer momento; as forças sociais e culturais que moldam a vida de uma pessoa ou . população". O mesmo dicionário define a ecologia como: "o ramo da biologia que lida com as relações e interações entre organismos e com o Ambiente (natural); o conjunto de relações existentes entre os organismos e seu ambiente" Partindo dessas definições, pode-se facilmente ver que a ecologia e meio ambiente, embora eles estão muito relacionados, não são uma mesma coisa (MEBRATU, 1998)

Um dos resultados da falta de compreensão científica do conceito da sustentabilidade é a natureza monótona do diálogo que circunda a questão ética. Embora a importância da ética para qualquer tipo de transformação social seja inegável, a incapacidade de desenvolver uma compreensão adequada e para mecanismos de sustentabilidade, levou a uma propagação fora de proporção do papel da "ética". 
Basicamente, a ética é um importante atributo de determinado meio que visa atingir um fim, e não um meio para se alcançar o fim. Embora o debate ético vigente baseia-se em polarizar a suposta tensão entre as posições antropocêntricas e ecocêntricas, em uma visão mais holística não se pode ser ecocêntrica sem ser antropocêntrica primeiro.

Em uma outra analise, na ausência de um ponto comum de saída, tal como uma definição comum sobre sustentabilidade, seria impossível seguir direções visionárias que levariam ao mesmo parâmetro de alcançar um mundo sustentável

Apesar de um tanto quanto debatido, o conceito de desenvolvimento sustentável vem evoluindo com o auxilio da comunidade acadêmica, que promove por vezes, dialéticas a respeito de sua origem e seus principais pontos de vista. $O$ autor analisado debate exatamente estes aspectos do desenvolvimento sustentável, contudo este não aponta as novas tendências existentes nos trabalhos publicados posteriormente a este capitulo.

\section{Referências}

BARBIERI, J.C. Inovação e sustentabilidade: novos modelos e proposições. Revista administração empresarial, São Paulo, v. 50, n. 2, Junho 2010.

BARBIERI, J.C.. Gestão Ambiental Empresarial: Conceitos, Modelos e Instrumentos. 1.ed. São Paulo: Saraiva. 2004.

BELLEN, H.M.V.. Desenvolvimento Sustentável: Uma Descrição das Principais Ferramentas de Avaliação. Ambiente \& Sociedade - v.7, n.1 jan./jun. 2004.

FERREIRA, D. Desenvolvimento Sustentável ou Mercantilização e Financeirização da Natureza? Revista de Administração e Negócios da Amazônia, v.5, n.3, set/dez. 2013.

GALLO E. Saúde e economia verde: desafios para o desenvolvimento sustentável e erradicação da pobreza. Ciência \& Saúde Coletiva,v.17, n.6, p.1457-1468, 2012.

MEBRATU, D. Sustainability and Sustainable Development: Historical And Conceptual Review. International Institute for Industrial Environmental Economics, Lund University. Environment Impact Asses Review. v.18, p.493-520. 1998.

NASCIMENTO, L F M.; LEMOS, A. D. C.; MELLO, M. C. A.. Gestão Socioambiental Estratégica. Porto Alegre: Bookman, 2008. 
RAVEN, P.H.; EVERT; R.F.; EICHHORN, S.E., Biologia Vegetal. GUANABARA KOOGAN, 6a Ed. 2001.

TEIXEIRA, C. O desenvolvimento sustentável em unidade de conservação: a "naturalização" do social. Revista brasileira de Ciências Sociais. [online]. 2005, v.20, n.59, p. 51-66.

TORRESI, S I. C; PARDINI, V L.; FERREIRA, V F. O Que É Sustentabilidade? Editorial, Química. Nova, v. 33, n.1, 5, 2010.

VECCHIATTI, K. Três fases rumo ao desenvolvimento sustentável: do reducionismo à valorização da cultura. São Paulo Perspec. [online]. 2004, v.18, n.3, p. 90-95.

WCED. Comissão Mundial Sobre Meio Ambiente e Desenvolvimento. Nosso Futuro Comum. $2^{\circ}$ edição Editora da Fundação Getulio Vargas. Rio de Janeiro, RJ 1991.

MEADOWS, D. H.; MEADOWS, D. L.; RANDERS, J.; BEHRENS, W. The Limits to Growth: A Report for The Club Of Rome's Project on the Predicament of Mankind. Universe Books: New York, 1972 


\section{Cenário das Indústrias de Beneficiamento do Pescado em Rondônia}

Jucilene Cavall28, Marlos Oliveira Porto ${ }^{29}$, Leticia Matias Pinheiro ${ }^{30}$, Thalitta Silva Cota $^{31}$, Mario Lima ${ }^{32}$, Elvino Ferreira ${ }^{33}$, Fabiane Bazzi Rocha ${ }^{34}$, Beatriz Andrade Nóbrega ${ }^{35}$, Célio Tessinari Rocha ${ }^{36}$

\section{Introdução}

O Estado de Rondônia é o maior produtor de Pescado em águas interiores do Brasil, com crescimento da piscicultura em $300 \%$ em 2013, possui aproximados 8.500 piscicultores (MPA, 2014), dispõe de 10.384 hectares de lâmina de água e produção de pescado estimada em 62,3 mil toneladas de pescado/ano (SEDAM, 2014), possui 3.250 propriedades licenciadas, sendo que $80 \%$ correspondem à produção de Tambaqui, Pirarucu, Jatuarana e Pintado e, apresentam um grande potencial almejando tornar-se o maior produtor de pescado do Brasil.

Os sistemas de cultivo de pescado na região caracterizam-se por sistema de produção semi-intensivo em viveiros escavados, com a média de 6 a 10 toneladas de pescado por hectare, e destaque a produção de espécies com escamas como a produção do tambaqui (Colossoma macropomum), que rege $90 \%$ do pescado cultivado no estado, seguido do Pirarucu (Arapaima gigas), maior peixe com escamas da ictiofauna de água doce do mundo, podendo atingir $13 \mathrm{~kg} \mathrm{em} 12$ meses de cultivo (ONO et al. 2004);

A organização e estruturação do setor de comercialização paralelo ao crescimento da produção são fundamentais para garantir a sustentabilidade da

\footnotetext{
28 Dra em Zootecnia. Departamento de Engenharia de Pesca da UNIR. jcavali@unir.br

29 Dr em Zootecnia. Departamento de Zootecnia da Universidade Federal de Rondônia.

30 Engenheira de Pesca. Secretaria do Estado de Desenvolvimento Ambiental, SEDAM.

31 Engenheira de Pesca. Autônoma.

32 Engenheiro de Pesca. Mestrando em Zootecnia. Instituto Federal Goiano, IFG.

33 Zootecnista. Dr em Zootecnia. Departamento de Medicina Veterinária da UNIR.

34 Engenheira de Pesca. Autônoma.

${ }^{35}$ Bolsista PIBIC/CNPq. Acadêmica em Engenharia de Pesca, UNIR.

${ }^{36}$ Engenheiro de Pesca. Secretaria do Estado de Desenvolvimento Ambiental, SEDAM.
} 
cadeia produtiva do pescado, uma vez que atrela produção e geração de renda através da fixação direta e indireta de mão de obra, abertura de novos nichos de mercado através dos produtos e cortes agregando de valor ao pescado comercializado, segurança comercial aos piscicultores quanto ao escoamento da produção. Estima-se que o valor do pescado processado pode alcançar preços até dez vezes maiores que o produto in natura. Segundo Almeida (2006) os frigoríficos contribuem com $36 \%$ da renda total gerada pelo setor pesqueiro na Amazônia.

Os frigoríficos de pescado sob inspeção e dotados de equipamentos e processos produtivos modernos, obedecendo aos padrões fixados pela legislação pertinente, pode oferecer ao mercado consumidor uma grande variedade de produtos de qualidade garantindo a segurança alimentar e praticidade ao consumidor, daí a importância em se direcionar investimentos e apoio ao desenvolvimento das industrias de beneficiamento no Estado de Rondônia.

\section{Contextualização das indústrias de pescado no Estado de Rondônia}

O Estado de Rondônia produziu cerca de 64 mil toneladas/ano de pescado, segundo o departamento de Comunicação do Social do Estado de Rondônia (DECOM, 2014) e cerca de 50 toneladas/ano de pescado segundo o IDARON (2014). Deste, as três maiores indústrias de beneficiamento do Pescado, dadas pelo Zaltana Pescados, Indústria Santa Clara e Mar \& Terra, compram juntas cerca de 9,5 mil ton/ano de pescado que representa 800 ton/mês de pescado (Figura 1) .

Figura 1. Principais Indústrias que processam o Pescado de Rondônia Zaltana Pescados, Agroindústria Santa Clara e Mar \& Terra

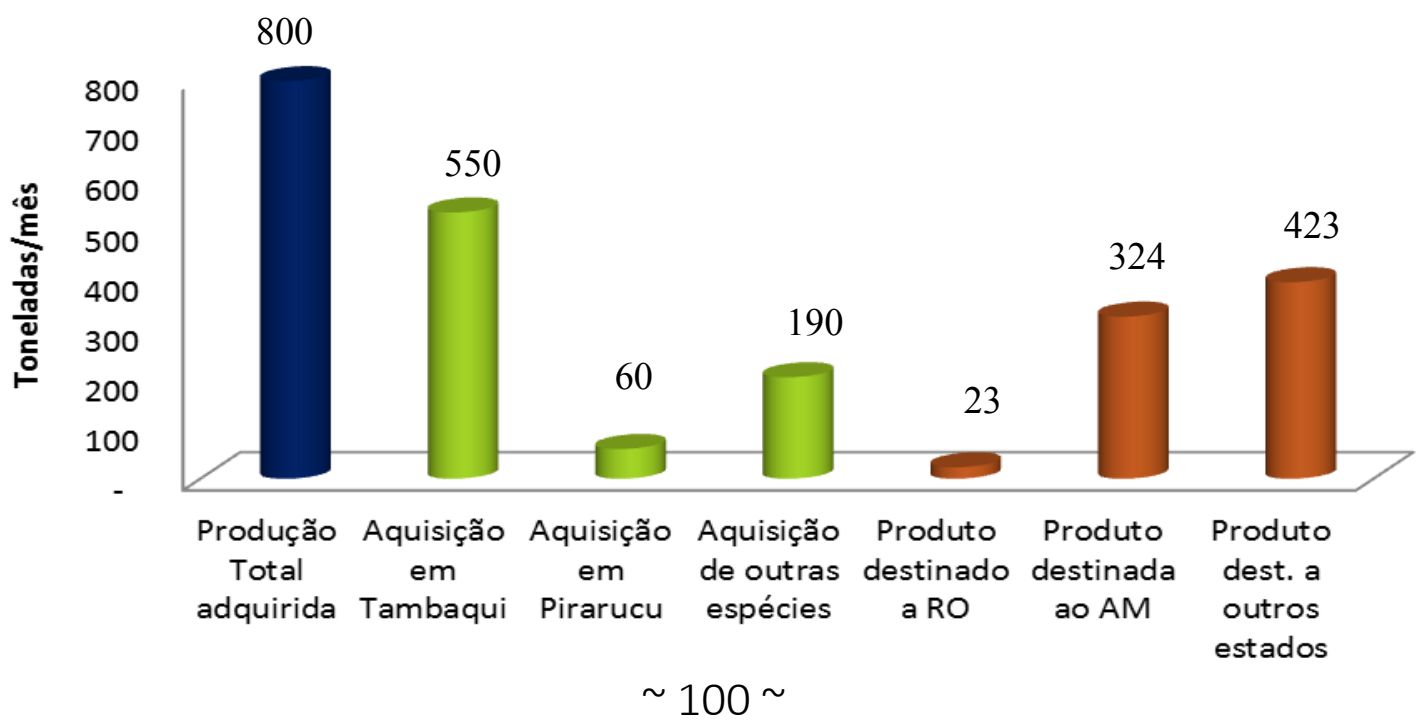


A pesquisa foi desenvolvida pelo Departamento de Engenharia de Pesca da Universidade Federal de Rondônia em parceria com a Escola Estadual Enaldo Lucas de Oliveira, com apoio da VALE/CNPq e dos frigoríficos do Estado de Rondônia de março de 2013 a março de 2014. Realizou-se um levantamento, vistas e aplicação de questionário nas Unidades de processamento de pescado dotadas de Serviço de Inspeção Federal (SIF) de maior atuação no Estado de Rondônia sendo: Zaltana Pescados localizado em Ariquemes, Indústria Santa Clara, sediada em Vilhena e Mar \& Terra Pescados, com Centro de produção em Pimenta Bueno e frigorífico no Mato Grosso do Sul, sendo as duas primeiras em funcionamento no estado, possibilitando a coleta detalhada das informações. Outras quatro unidades frigorificas encontram-se em não funcionamento ou desativadas.

Juntas estas unidades beneficiadoras atendem cerca de 27 municípios adquirindo pescado de 145 pisciculturas no Estado, considerando associações e cooperativas como fornecedores/pisciculturas. Contudo, a produção adquirida pela Mar \& Terra é transportada ao Estado do Mato Grosso do Sul onde está sediada sua indústria frigorífica.

Ressalta-se que o consumo de pescado em Rondônia é de $8 \mathrm{~kg} /$ pessoa/ano, o que representa 1.022 ton/mês. Sendo apenas 23 ton/mês destinada pelos frigoríficos ao mercado local, infere-se que $97 \%$ do pescado consumido no Estado não advém dos frigoríficos.

Considerando-se apenas os dois frigoríficos existentes no Estado (Figura 2), sendo um na região Norte, município de Ariquemes (Zaltana Pescados) SIF e outro na região Sul do Estado em Vilhena (Indústria Santa Clara), ambos são regularizados com Selo de Inspeção Federal (SIF), têm capacidade média de abate de 22 mil $\mathrm{kg} / \mathrm{dia}^{2}$, e suprem, através de pisciculturas próprias, cerca de $75 \%$ da produção. Ressalta-se que ambas as unidades estão sendo redimensionadas em expansão e tecnificação a fim de melhor atender o mercado.

Comercializam $65 \%$ do pescado in natura ao mercado do Amazonas (especialmente tambaqui) e transformam $35 \%$ do pescado em produtos. O comércio in natura abrange aproximadamente $300 \%$ a mais que o processado na região, sendo o principal destino o mercado de Manaus.

Das espécies comercializadas nas indústrias, o tambaqui representa $93 \%$ do pescado que passa pelos frigoríficos, comercializado especialmente à Manaus, seguido do Pirarucu com $4 \%$ do montante e $3 \%$ de outras espécies como o pintado, tilápia, etc. São gerados 10 segmentos de cortes/produtos do tambaqui e quatro do pirarucu: tambaqui inteiro eviscerado e borboleta, lombo inteiro, ticado, costela inteira 
e fatiada, postas, manta, cabeças, filés, trazendo praticidade e qualidade ao consumidor.

Figura 2. Principais Indústrias que processam o Pescado em Rondônia Zaltana Pescados e Agroindústria Santa Clara

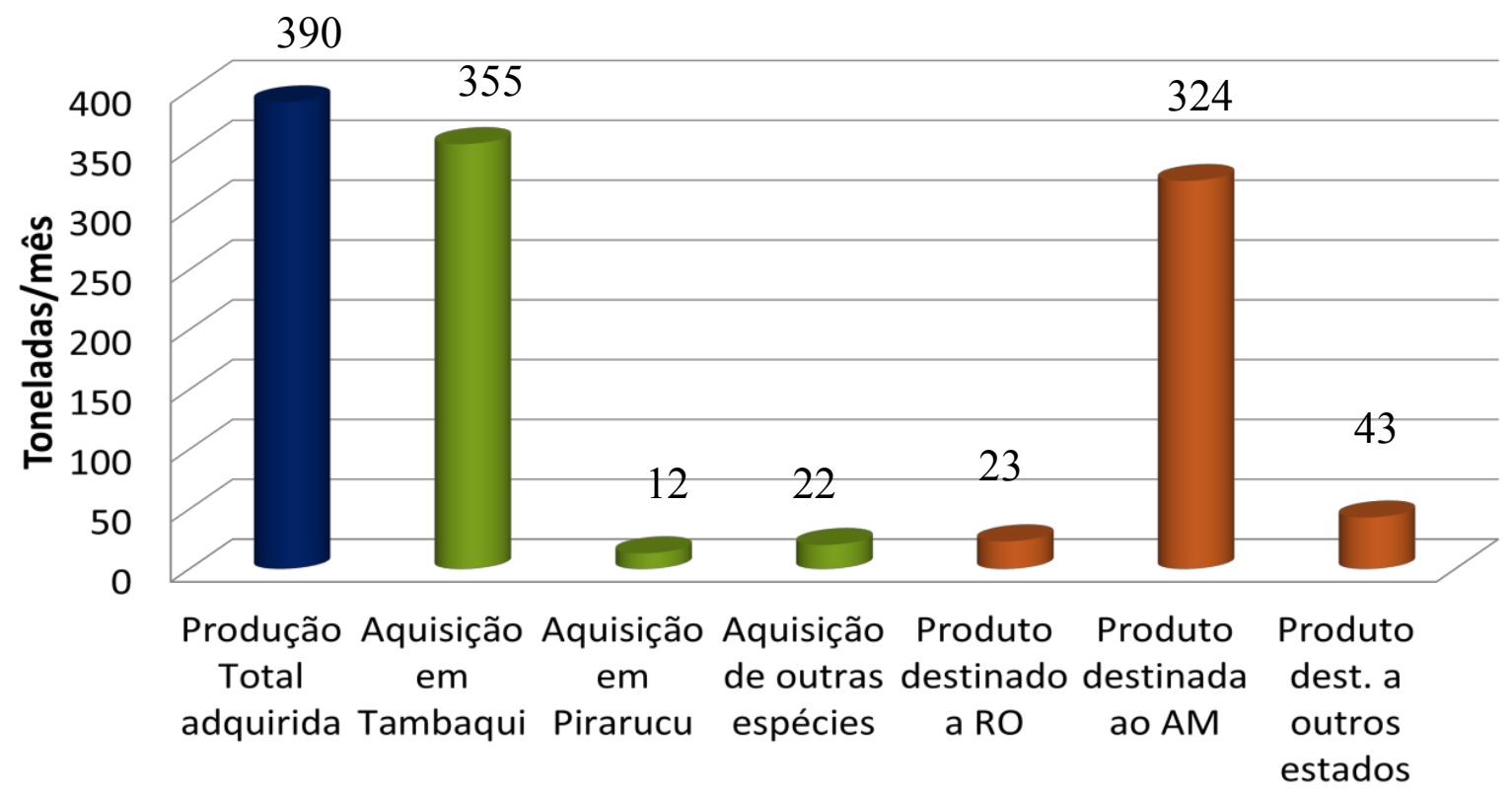

\section{Descrição e etapas do beneficiamento}

Ainda na piscicultura, os peixes passam pelo manejo pré-captura com jejum do ultimo trato, são capturados e alocados em caminhões dotados de caixas refrigeradores onde são insensibilizados em água e gelo na relação 1:1, que permite morte rápida do animal e mínimo de sofrimento (VARGAS 2011) reduzindo a resposta às condições de estresse ao abate, além de facilitar o manejo dos peixes e melhor sangria.

$\mathrm{Na}$ indústria são selecionados, pesados e armazenados em câmara de espera e/ou encaminhados diretamente para processamento onde são lavados à concentração de 5-6 ppm de cloro em cilindros de lavagem para retirada do muco.

Da caracterização das etapas do abate, ambas as indústrias seguem um fluxograma simplificado de etapas e operações de processamento do pescado que inicia na piscicultura com a depuração, até a etapa do congelamento, fase de expedição. Antes da captura, os animais são submetidos ao processo de depuração 
por 24-48 horas, a fim de limpar do trato digestivo, reduzindo o conteúdo gastrointestinal e a carga microbiológica.

\section{Etapa da evisceração}

Consiste principalmente na retirada das vísceras e toalete, remoção das partes comercialmente indesejáveis como vísceras, couro, etc. e, de acordo com a espécie e o corte comercial adotado, retira-se a cabeça e as escamas (Figura 3). Para o pirarucu, nas situações onde o couro é destinado ao curtume, é retirado inteiro sem danificações o que aumenta o tempo de abate e custo com mão-de-obra na indústria. Para as maiores espécies, a exemplo do pintado (Pseudoplatystoma fasciatum), pirarucu (Arapaima gigas) e exemplares de peso médio de tambaqui (Colossoma macropomum), dá-se origem a carcaça ou corpo limpo, livre de couro e escamas. Já tambaquis acima de $3 \mathrm{~kg}$ são comumente eviscerados, mantendo-se a cabeça e as escamas na carcaça.

Figura 3. Etapa de seleção do tambaqui, evisceração e retirada do couro do pirarucu na indústria.
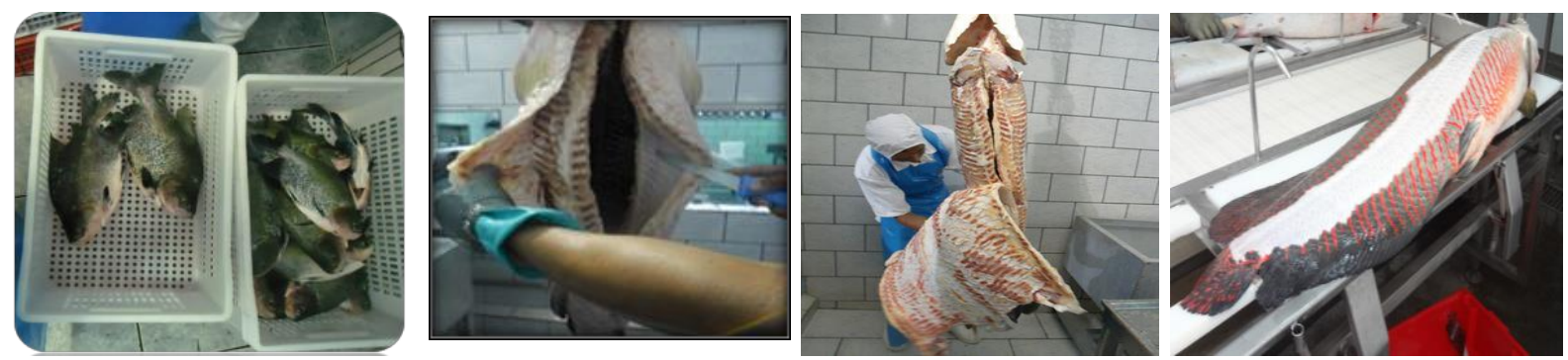

Fonte: Zaltana Pescados e Agroindustria Santa Clara.

As carcaças, após lavagem em agua clorada, seguem para a área limpa ou sala de cortes, onde é convertida em cortes comercializáveis.

Da área suja o pescado segue para a Área limpa onde retirado os espinhos do lombo e cauda, lavados novamente em água clorada e onde são realizados os cortes. Os cortes, embalados segundo a classificação são armazenados em túnel de congelamento onde permanecem ate atingir a temperatura de $<-18^{\circ} \mathrm{C}$. 
Figura 4. Etapa de processamento, filetagem e seleção nas indústrias de pescado.
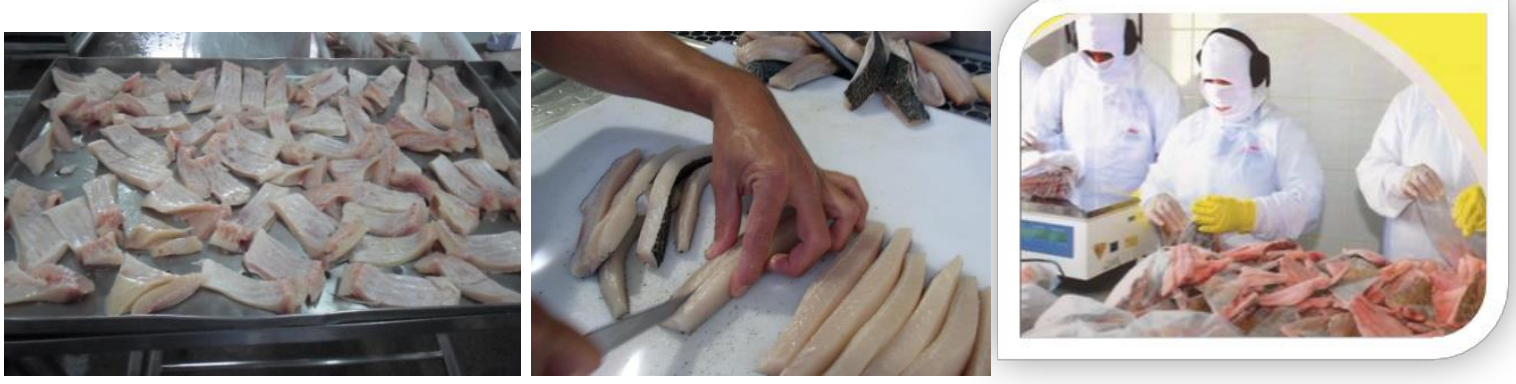

Nos supermercados da região é possível encontrar produtos, mesmo que em pequena escala e predominantemente na forma Pescado Inteiro Eviscerado, dos Frigorificos processadores de pescado no Estado de Rondônia.
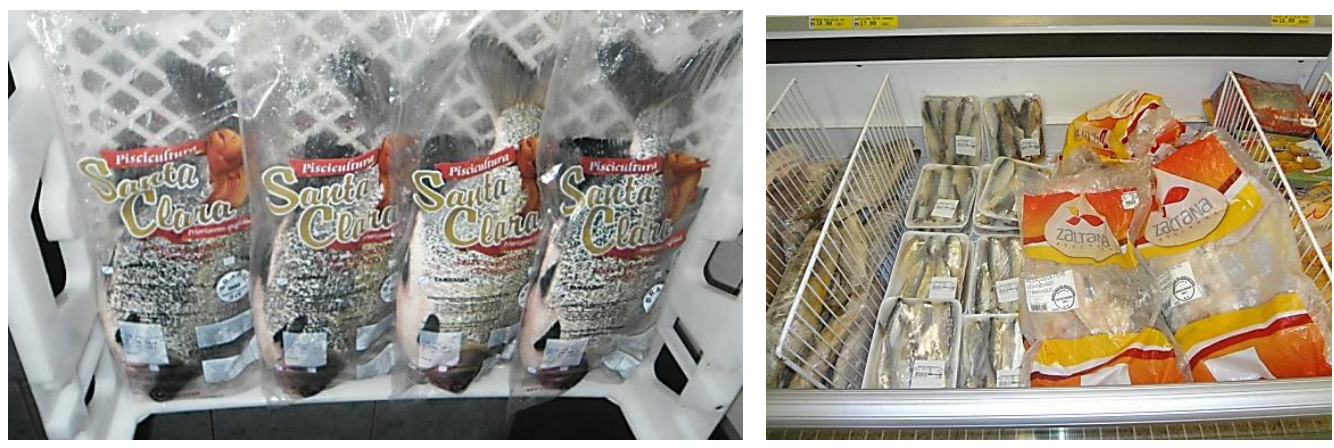

\section{Industrialização e comercialização do pescado}

São realizados variados segmentos de cortes e produtos conforme a espécie beneficiada. Atualmente para o tambaqui, carro chefe da linha de produção das indústrias regionais representando $93 \%$ do processado, pirarucu e pintado são preparados cerca de 10 produtos, sendo os principais; inteiro eviscerado e borboleta, lombo inteiro, ticado, banda, filé, costela inteira e fatiada, postas, manta, cabeças e petiscos. Para a grande maioria dos cortes são retirados os espinhos e espinhaços, indesejáveis para o consumidor.

Os produtos a serem comercializados são mantidos em túnel de congelamento a $-20^{\circ} \mathrm{C}$ e passa pelo grazing com temperatura entre $1^{\circ} \mathrm{C}$ a $-2^{\circ} \mathrm{C}$ (camada de água/gelo) que serve de proteção da desidratação e oxidação, aumentar a durabilidade e conservar a aparência do pescado, posteriormente são encaminhados a sala de estocagem a $-18^{\circ} \mathrm{C}$, de onde serão expedidos por meio de caminhões dotados de baús frigoríficos refrigerados.

As empresas dispõem de tecnologia de embalagem a vácuo, sistema que permite maior conservação do produto em relação aos outros sistemas de 
embalagem, etiquetados com as principais especificações de registro. $O$ beneficiamento do pescado expande os nichos de comercialização, agrega qualidade e valor aos produtos e gera renda e emprego. Segundo Almeida (2006) os frigoríficos contribuem com $36 \%$ da renda total gerada pelo setor pesqueiro na Amazônia.

O valor de aquisição do tambaqui varia de $R \$ 3,25$ a 3,50, já para o pirarucu de $\mathrm{R} \$ 7,75$ a $\mathrm{R} \$ 8,00$. O valor agregado ao tambaqui e pirarucu, espécies mais comercialização no Estado, é de aproximadamente $420 \%$ e $225 \%$, respectivamente, considerado lucrativo para as indústrias (Figura 5).

Figura 5. Custo médio por $\mathrm{kg}$ da comercialização do tambaqui e pirarucu, em Rondônia

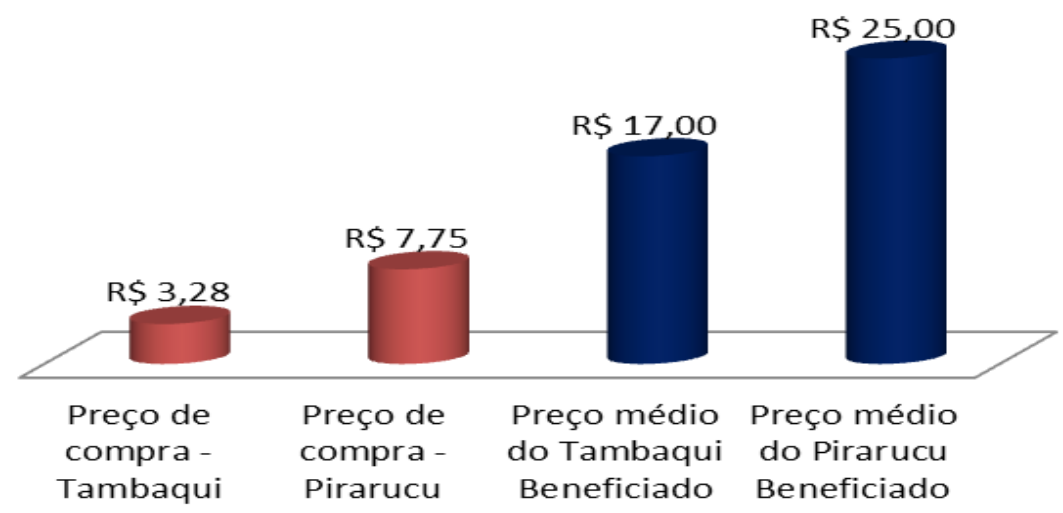

As indústrias frigorificas de pescado de Rondônia estão em processo de expansão e tecnificação do sistema a fim de tornar os processos mais eficientes, oportunizar novos produtos e nichos comerciais, trazendo mais qualidade e praticidade ao consumidor, além de melhor atender a demanda comercial do pescado com maior rentabilidade ao produtor e sustentabilidade da produção de pescado. Maiores investimentos no setor de comercialização do pescado em Rondônia são necessários para atender a demanda da produção. A indústria pesqueira está cada vez procurando adquirir alto potencial de desenvolvimento com excelentes programas, oferecendo aos consumidores produtos de qualidade e saudáveis com excelente potencial. 


\section{Considerações finais}

A importância de um frigorífico de peixe não se dá apenas por gerir a cadeia de produção, mas também pelas etapas de processamento e beneficiamento que este concede ao peixe. A indústria de beneficiamento de pescado, com equipamentos e processos produtivos modernos, obedecendo aos padrões fixados pela legislação pertinente, pode oferecer ampla diversidade de produtos ao mercado consumidor, busca praticidade e rapidez no preparo de alimentos oriundos do pescado.

O Estado de Rondônia possui duas indústrias frigoríficas de pescado ativas que respondem pelo beneficiamento de menos que $20 \%$ da produção; cenário ainda incipiente perante a importância da estruturação do setor de comercialização na cadeia de produção do pescado no Estado de Rondônia e às vantagens sócioeconômicas agregadas com beneficiamento do pescado pela expansão dos nichos de comercialização, agregação de valor aos produtos e geração de renda e emprego.

\section{Referencias}

ALMEIDA, O.; AMARAL, L.; RIVERO, S.; A mão-de-obra da indústria pesqueira na Amazônia. Novos Cadernos NAEA v. 9, n. 2, p. 5-24, dez. 2006.

ARGENTA, F. F.; Tecnologia de pescado: características e Processamento da matéria-prima. Porto Alegre, 2012.

BRASIL, Ministério da Agricultura Pecuária e Abastecimento. RIISPOA: Regulamento da Inspeção Industrial e Sanitária de Produtos de Origem Animal. Decreto $\mathrm{n}^{\circ}$ 120.691. Brasília: 1984.

JOSÉ LUIZ ALVES/Decom/RO. Produção de pescado. Amazônia da gente. Disponível em http://www.amazoniadagente.com.br/?p=13153. Acessado no dia 06/03/2014.

MINISTERIO DA PESCA E AQUICULTURA - MPA. Disponível em: http://www.mpa.gov.br/>. Acesso em: 05/03/2015.

SECRETARIA DO ESTADO DO DESENVOLVIMENTO AMBIENTAL; Disponível em: <http://www.sedam.ro.gov.br/>.Acessado no dia 06/03/2015. 
VARGAS, S.C. Avaliação de métodos de abate sobre a qualidade da carne e matrinxã (Brycon cephalus), armazenados em gelo. Dissertação (Mestrado em Zootecnia) 2011. 82p.

\section{Agradecimentos}

A VALE S.A. e CNPq pelo apoio financeiro no Edital Forma-Engenharia; Aos Frigoríficos Zaltana Pescados, Indústria Santa Clara e Mar \& Terra e Cooperativas pela contribuição ás informações. 


\title{
Regularização de projetos de piscicultura no estado de Rondônia
}

\author{
Atielli Crislian de Oliveira ${ }^{37}$, Luís Cláudio Tamborim Júnior ${ }^{38}$, Ricardo Henrique \\ Bastos de Souza ${ }^{39}$, Jucilene Cavali ${ }^{40}$, Juliana Ferraz Huback Rodrigues ${ }^{41}$
}

\section{Introdução}

A piscicultura, tem se tornado uma importante atividade rural no Brasil e principalmente no Estado de Rondônia. Os recursos hídricos, as condições climáticas, disponibilidade de matéria prima e a proximidade do mercado consumidor, colocam o Estado em destaque na produção aquícola brasileira.

Segundo a FAO (2012) a produção aquícola mundial em 2010 foi de 60 milhões de toneladas. No Brasil, na mesma época, a produção total da aquicultura, foi de 415.649 toneladas sendo 337.353 toneladas produzidas pela piscicultura, das quais $81,2 \%$ foram oriundas da produção de organismos aquáticos continentais (MPA, 2012). Em Rondônia, a produção de pescado advém, em maior proporção, da piscicultura continental, principalmente da produção de tambaqui (Colossoma macropomum), onde de acordo com a Secretaria de Estado da Agricultura, Pecuária e Regularização Fundiária (SEAGRI), na safra 2012/2013 a produção foi de aproximadamente 48 mil toneladas, sendo que para 2014, a estimativa é de 70 mil toneladas.

Entendendo a importância da atividade e da legalização dos empreendimentos, é necessária a compreensão e orientações acerca das legislações e procedimentos para a obtenção da autorização de uso de espaços físicos de corpos d'água de domínio da União e para o requerimento da licença ambiental no Estado de Rondônia.

\footnotetext{
37 Analista Ambiental. Engenheira de Pesca. Analista Ambiental. Secretaria Municipal da Pesca e Aquicultura da SEMAGRI. atielli_@hotmail.com.br

38 Engenheiro Agrônomo. Secretaria Municipal da Pesca e Aquicultura. Porto Velho.

39 Engenheiro de Pesca. Departamento de Engenharia de Pesca da Universidade Federal de Rondônia.

40 Dra em Zootecnia. Departamento de Zootecnia da universidade federal de Rondônia.

41 Zootecnista. Dra em Zootecnia. Programa de Pós Graduação em Ciências Ambientais da Universidade Federal de Rondônia.
} 
Dentre as legislações, destacamos a Lei Complementar $n^{\circ} 140$, de 08 de dezembro de 2011, Lei Federal, que determina as competências dos órgãos ambientais da União, dos Estados, do Distrito Federal e dos Municípios, tendo em vista o uso racional dos recursos ambientais. Esta lei determina que o Licenciamento Ambiental deva ocorrer em um único nível de competência, resguardando para cada órgão o exercício de sua competência para as ações de fiscalização e de licenciamento. Segundo Dell'orto et al. (2012), a presente lei é de grande importância, visto que sistematiza de maneira racional a distribuição de competências no que tange a gestão ambiental, minimizando consideravelmente a insegurança gerada pelo regramento da matéria que antes era normatizada por meio da Resolução $n^{\circ} 237 / 97$ do Conselho Nacional do Meio Ambiente (CONAMA).

O Licenciamento Ambiental foi instituído no Brasil pela Lei 6.938/81. Este instrumento faz parte da Política Nacional de Meio Ambiente e deve ser aplicado as atividades efetivas, potencialmente poluidoras ou degradadoras do meio ambiente, previstas nas Resoluções do CONAMA 001/86, 011/87, 006/88, 009/90, 010/90 e 013/90. A Resolução 237/97, em seu Anexo I, incorporou as atividades agropecuárias ao licenciamento ambiental. A Portaria $n^{\circ}$ 203/01 MMA, em seu Art. $1^{\circ}$, instituiu o Licenciamento Ambiental em Propriedades Rurais na Amazônia Legal. A Portaria $n^{\circ}$ 09/02 IBAMA estabeleceu o roteiro e as especificações técnicas para o Licenciamento Ambiental em Propriedade Rural e a Portaria $n^{\circ}$ 303/03 do MMA estabeleceu o prazo de $1^{\circ}$ de julho de 2004 para que as autorizações de desmatamento sejam liberadas somente mediante o Licenciamento Ambiental da Propriedade Rural.

Dell'orto (2012) caracteriza o Licenciamento Ambiental pelo procedimento no qual o poder público, representado por órgãos ou entidades ambientais, autoriza e acompanha a implantação e a operação de atividades, que utilizam recursos naturais ou que sejam consideradas efetiva ou potencialmente poluidoras. Por outro lado, a Licença Ambiental é um documento emitido pelos órgãos ambientais, com prazo de validade definido, que autoriza o empreendedor a exercer a atividade e pode ser cassada caso as condições, restrições e medidas de controle estabelecidas não sejam cumpridas.

É importante ressaltar, que além da obrigatoriedade legal, a Licença é requisito para obtenção de financiamentos, guias de transportes e certificação de produtos, tanto para o mercado interno quanto para o externo.

Existem três tipos de Licenças necessárias para o funcionamento do empreendimento:

Licença Prévia (LP) - concedida na fase preliminar do planejamento do empreendimento ou atividade, aprovando sua localização e concepção, atestando a 
viabilidade ambiental e estabelecendo os requisitos básicos e condicionantes a serem atendidos nas próximas fases de sua implementação com validade 5 anos;

Licença de Instalação (LI) - autoriza a instalação do empreendimento ou atividade de acordo com as especificações constantes dos planos, programas e projetos aprovados, incluindo as medidas de controle ambiental e demais condicionantes, da qual constituem motivo determinante com validade 6 anos;

Licença de Operação (LO) - autoriza a operação da atividade ou empreendimento, após a verificação do efetivo cumprimento do que consta das licenças anteriores, com as medidas de controle ambiental e condicionantes determinados para a operação com validade 4 a 10 anos.

A regularização ou legalização dos empreendimentos de piscicultura é ferramenta importante para o direcionamento da atividade, pois visa viabilidade econômica, com sustentabilidade ambiental, evitando conflitos no uso de recursos hídricos e promovendo o desenvolvimento regional. Esse artigo sintetiza as informações para legalização dos projetos de piscicultura em tanques-rede e viveiros escavados no Estado de Rondônia, com o objetivo de servir de orientação a técnicos e produtores rurais.

\section{Regularização de projetos de piscicultura em tanques-rede}

De acordo com a Constituição Federal de 1.988, artigo 20 e 26, respectivamente:

\footnotetext{
"são bens da União os lagos, rios e quaisquer correntes de água em terrenos de seu domínio, ou que banhem mais de um Estado, sirvam de limites com outros países, ou se estendam o território estrangeiro ou dele provenham, bem como os terrenos marginais e as praias fluviais; geologia e cartografia de âmbito nacional" (...)

e ... "são bens do Estado as águas superficiais ou subterrâneas, fluentes, emergentes e em depósito, ressalvadas, neste caso, na forma da lei, as decorrentes de obras da União" (...)."
}

A legislação pertinente à aquicultura no sistema de tanques-rede é bastante complexa, particularmente, quando se trata de projetos em águas da União que são regulamentados por normas jurídicas referentes a distintos setores (produção animal, recursos hídricos, saúde, dentre outros) e à sobreposição de atos normativos (decretos, portarias, resoluções e deliberações) (AYROZA et al 2008). 
Em artigo publicado na Revista Tecnologia \& Inovação Tecnológica, Ayroza (2008) cita que o resultado disso é que a regularização dos empreendimentos envolve a elaboração de vários projetos e etapas em diferentes instituições governamentais.

No âmbito legal, outro problema é que a atividade é tratada no mesmo escopo legal que as demais atividades que utilizam o recurso hídrico, tais como mineração e aproveitamento de energia elétrica.

Na visão de Ayroza (2008), é necessário melhorar a articulação entre o Sistema Nacional de Gerenciamento de Recursos Hídricos e os sistemas estaduais para efetivação da gestão das águas, uma vez que não existe uma padronização para a regularização dos projetos aquícolas instalados em águas da União e em águas do Estado. Ressalta-se que é necessária a regularização do empreendimento junto à concessionária, além do pagamento de uma taxa anual.

\section{Projetos em águas da união}

Os órgãos envolvidos no processo de regularização dos projetos aquícolas na esfera Federal são: Ministério da Pesca e Aquicultura (MPA), Instituto Brasileiro do Meio Ambiente e dos Recursos Naturais Renováveis (IBAMA), Autoridade Marítima, Agência Nacional de Águas (ANA) e Secretaria de Patrimônio da União do Ministério do Planejamento, Orçamento e Gestão (SPU/MP).

O Ministério da Pesca e Aquicultura (MPA) é o órgão centralizador do procedimento para autorização dos projetos de piscicultura em tanques-rede. Esse órgão é responsável pela análise técnica do projeto, tendo como foco a localização adequada do empreendimento no reservatório e as questões técnicas do cultivo; pelo encaminhamento para a Marinha, IBAMA e ANA; pelo processo de licitação para a efetivação e entrega da autorização de uso dos espaços físicos em corpos d'água de domínio da União para fins de aquicultura (cessão de uso), lavrado pela Secretaria de Patrimônio e Gestão (SPU) e pela emissão do Registro de Aquicultor.

O empreendedor ou o requerente deverão protocolar no Escritório da Superintendência do Ministério da Pesca e Aquicultura no Estado de Rondônia, quatro vias do projeto para autorização de uso dos espaços físicos em corpos d'água de domínio da União, para fins de aquicultura. Esse projeto é elaborado conforme o Decreto $n^{\circ}$. 4.895, de 25 de novembro de 2003 e da Instrução Normativa Interministerial $n^{\circ}$. 6, de 31 de maio de 2004 (AYROZA et al 2008). 
A elaboração desse projeto envolve as seguintes atividades:

- Avaliação das características locais para seleção da área de implantação do projeto;

- Georreferenciamento do polígono externo da área do projeto e pontos de referência;

- Relatório fotográfico;

- Elaboração do projeto técnico de criação de peixes no sistema de tanquesrede;

- Preenchimento dos anexos I e II da INI N 6/2004;

- Confecção de mapa contendo a localização do empreendimento com escala entre 1:25.000 e 1:75.000 e;

- Elaboração de planta do perímetro externo do empreendimento com escala entre 1:100 e 1:5.000 e planta de construção de equipamentos em escala que caracterize os mesmos.

A Autoridade Marítima emite o parecer sobre a segurança do tráfego Aquaviário e orienta como proceder à demarcação do projeto piscícola, conforme NORMAM 17/2004, que trata da sinalização náutica.

A Agência Nacional de Águas (ANA) fornece a outorga de uso das águas públicas. Cabe ao Poder Público gerenciar os recursos hídricos de forma a atender a todas as demandas, uma vez que são bens públicos e todos têm direito ao acesso ou uso. Os usos que alteram o regime, a quantidade ou qualidade da água existente em um corpo d’água são passíveis de outorga.

O Instituto Brasileiro do Meio Ambiente e dos Recursos Naturais Renováveis (IBAMA) realiza a análise prévia das questões ambientais para o Licenciamento Ambiental. Ao dar entrada do processo no Ministério da Pesca e Aquicultura (MPA) é obrigatório o cadastramento do empreendedor no Cadastro Técnico Federal de Atividades Potencialmente Poluidoras ou Usuárias de Recursos Naturais Renováveis.

A Secretaria de Patrimônio da União do Ministério do Planejamento, Orçamento e Gestão (SPU) lavra o "Termo de Entrega" ao solicitante da área aquícola, em última análise, a partir do processo licitatório instalado pelo MPA e em observância ao Decreto 4.895/2003 e à INI No 6/2004. Esse documento efetiva a autorização de uso dos espaços físicos em corpos d'água de domínio da União para fins de aquicultura (cessão de uso). É importante diferenciar duas situações: 
$1^{\circ}$ - a de uma área aquícola para uso individual ou coletivo, neste último caso, por exemplo, de uma associação, para a qual o empreendedor está pleiteando a autorização de uso e deve proceder a todas as etapas previstas nos itens acima;

$2^{\circ}$ - a de uma Área Aquícola dentro de um Parque Aquícola, que é um espaço físico contínuo em meio aquático, delimitado, que compreende um conjunto de áreas aquícolas afins (semelhante a um loteamento), em relação ao qual o MPA já teria cumprido todo o trâmite antes de dar início à licitação.

No caso dos projetos já implantados, o grande problema é que o produtor que já tenha feito o requerimento ao Ministério da Pesca e Aquicultura (MPA) e seguido todo o trâmite, obtendo os deferimentos dos órgãos competentes, não tem nenhum benefício em relação a outro produtor participante da licitação. O vencedor da licitação terá o prazo de um ano para obter todas as autorizações necessárias, sob pena de perder a cessão de uso. Entretanto, se o empreendedor não deu início aos procedimentos para a regularização do projeto, cumprir esse prazo é praticamente impossível.

\section{Projetos em águas do estado}

Para a regularização de empreendimentos localizados em águas estaduais, cujo reservatório não foi construído com verba da União, a princípio, é necessária a elaboração de um projeto nos mesmos moldes do projeto para águas da União, posteriormente análise da Autoridade Marítima e solicitação das devidas autorizações na esfera estadual, ou seja, Outorga, Licença Ambiental Prévia, Licença Ambiental de Instalação e Licença Ambiental de Operação, na Secretaria de Estado do Desenvolvimento Ambiental (SEDAM). Por último, o empreendedor deve solicitar o Registro Geral da Pesca no Ministério da Pesca e Aquicultura (MPA).

A SEDAM é a responsável pela regularização, legalização e fiscalização dos empreendimentos de piscicultura no Estado de Rondônia.

Os documentos necessários para abertura de processo de licenciamento são:

I - Requerimento padrão;

II - Cadastro do Aquicultor;

III - Outorga; 
IV - Certidão de Viabilidade da Atividade, emitido pela Prefeitura Municipal (de acordo com as leis municipais);

V - Licença da Propriedade Rural;

VI - Comprovante de recolhimento da taxa referente à licença solicitada;

VII - Atos constitutivos da empresa (se for empresa);

VIII - Xérox do cartão CNPJ;

IX - Xérox do CPF do responsável legal;

$X$ - Xérox do RG do responsável legal;

XI - Comprovante de publicação em jornal;

XII - Vistoria Técnica do Empreendimento/SEDAM;

XIII - Plano de Controle Ambiental (PCA).

\section{Projetos em represas de propriedades rurais}

Para legalização de tanques-rede instalados em represas de propriedades rurais, em nível estadual, necessita-se solicitar o Licenciamento Ambiental e a Outorga na Secretaria de Estado do Desenvolvimento Ambiental (SEDAM). Para pisciculturas em tanques-rede de até $200 \mathrm{~m}^{3}$, os empreendedores devem solicitar as referidas Licenças nas Secretarias Municipais de Meio Ambiente, pois a partir de junho de 2012, a SEDAM, através de um termo de cooperação, delegou as responsabilidades de licenciar os empreendimentos considerados de pequeno porte para os municípios, não dispensando as solicitações de licenças e outorga do direito de uso da água.

\section{Regularização de projetos de piscicultura em viveiros escavados}

No Estado de Rondônia, a regularização de projetos de piscicultura em viveiros escavados, acima de 05 (cinco) hectares de lâmina d'água, deve ser solicitada na SEDAM; até 05 (cinco) hectares de lâmina d'água houve a descentralização dos licenciamentos por parte da SEDAM para os municípios 
rondonienses, então, as Secretarias Municipais de Meio Ambiente são responsáveis pelo Licenciamento Ambiental da atividade. Especificamente no Município de Porto Velho, a Secretaria Municipal de Meio Ambiente (SEMA) possui em seu organograma, duas divisões que analisam os licenciamentos, a Divisão de Controle de Documentos (DICD) e a Divisão de Análise do Licenciamento (DIAL) que segundo - "Fluxograma de Licenciamento Ambiental", se não houver pendências documentais, a Licença Ambiental para Piscicultura será emitida em até 51 (cinquenta e um) dias.

Os documentos necessários para abertura de processo de licenciamento na Secretaria Municipal de Meio Ambiente (SEMA) de Porto Velho/RO são:

I - Requerimento Padrão;

II - Cadastro Simplificado;

III - Cópia do RG e CPF do responsável legal;

IV - CNPJ (se for empresa);

V - Comprovante de recolhimento das taxas ambientais pertinentes a categoria pretendida;

VI - Cópia do Contrato Social e alterações (se for empresa);

VII - Comprovante de propriedade do imóvel;

VIII - Planta baixa do empreendimento;

IX - Croqui de acesso;

X - Formulário de caracterização do empreendimento;

XI - Publicação em jornal;

XII - Relatório de Controle Ambiental (RCA);

XIII - Anotação de Responsabilidade Técnica (ART);

XIV - Cadastro Ambiental Rural (CAR).

Para projetos acima de 05 (cinco) hectares de lâmina d'água, são exigidos pela Secretaria de Estado do Desenvolvimento Ambiental (SEDAM) os seguintes documentos:

I - Requerimento padrão; 
II - Cadastro do Aquicultor;

III - Outorga;

IV - Certidão de Viabilidade da Atividade, emitido pela Prefeitura Municipal (de acordo com as posturas e leis municipais);

V - Licença da Propriedade Rural;

VI - Comprovante de recolhimento da taxa referente à licença solicitada;

VII - Atos constitutivos da empresa (se for empresa);

VIII - Xérox do cartão CNPJ;

IX - Xérox do CPF do responsável legal;

X - Xérox do RG do responsável legal;

XI - Comprovante de publicação em jornal;

XII - Vistoria Técnica do Empreendimento/SEDAM;

XIII - Plano de Controle Ambiental (PCA).

\section{Considerações finais}

A legalização dos projetos de piscicultura é complexa e, no caso do sistema de tanques-rede em águas de domínio da União, envolve um grande número de Órgãos Federais e Estaduais reguladores. Consequentemente, os procedimentos necessários para a regularização de um empreendimento piscícola são morosos e onerosos, exigindo capacitação técnica para a elaboração dos projetos para o licenciamento.

Para o maior desenvolvimento da piscicultura, no Brasil e em Rondônia, são necessárias ações de fomento da produção e estímulo à legalização dos empreendimentos, com utilização de modelos sustentáveis, regularização fundiária, acesso ao crédito bancário e isenções de taxas para produtores da agricultura familiar. 


\section{Referências}

AYROZA, L.M.S.; FURLANETO, F.P.B.; AYROZA, D.M.M.R.; SUSSEL, F.R. 2008. Regularização de Projetos de Piscicultura no Estado de São Paulo. Revista Tecnologia e Inovação Agropecuária, São Paulo, p. 33-41.

BRASIL. Constituição, 1988. Constituição da República Federativa do Brasil. 1998. Brasília: Senado. Disponível em: <http://www.planalto.gov.br>. Acesso em: 08 fev. 2014;

BRASIL. Decreto n. 1.695, de 13 de novembro de 1995. Regulamenta a exploração de aquicultura em águas públicas pertencentes à União e dá outras providências. Disponível em: < htpp://www.icmbio.gov.br > Acesso em: 13 maio. 2014.

BRASIL. Decreto n. 2.596, de 18 de maio de 1998. Regulamenta a Lei $n^{\circ}$ 9.537, de 11 de dezembro de 1997, que dispõe sobre a segurança do tráfego aquaviário em águas sob jurisdição nacional. Disponível em: <htpp://www.planalto.gov.br> Acesso em: 13 maio. 2014.

BRASIL. Decreto n. 4.895, de 25 de novembro de 2003. Dispõe sobre a autorização de uso de espaços físicos de corpos d'água de domínio da União para fins de aqüicultura, e dá outras providências. Disponível em: <htpp://www.planalto.gov.br> Acesso em: 13 maio. 2014.

BRASIL. Decreto n. 24.643, de 10 de julho de 1934. Decreta o Código de Águas. Disponível em: <htpp://www.planalto.gov.br> Acesso em: 13 maio. 2014.

BRASIL. Diário Oficial da União. Leis e Decretos. 2008. Disponível em: <http://www.imprensaoficial.com.br>. Acesso em: 25 jan. 2014.

BRASIL. Instrução Normativa Interministerial n.6, de 28 de maio de 2004. Estabelece as normas complementares para a autorização de uso dos espaços físicos em corpos d'água de domínio da União para fins de aquicultura, e dá outras providências. Disponível em: htpp:// www.planejamento.gov.br> Acesso em: 13 maio. 2014.

BRASIL. Instrução Normativa Interministerial N ${ }^{\circ}$ 8, de 26 de novembro de 2003. Estabelece diretrizes para implantação dos parques aquícolas. Disponível em: htpp:// www.planejamento.gov.br> Acesso em: 13 maio. 2014.

BRASIL. Instrução Normativa Interministerial n. 9, de 11 de abril de 2001. Estabelece normas complementares para o uso de águas públicas da União, para fins de 
aquicultura, e dá outras providências. Disponível em: htpp:// www.planejamento.gov.br> Acesso em: 13 maio. 2014.

BRASIL. Lei n. 6.938, de 31 de agosto de 1981. Dispõe sobre a Política Nacional do Meio Ambiente, seus fins e mecanismos de formulação e aplicação, e dá outras providências. Disponível em: <htpp://www.planalto.gov.br> Acesso em: 13 maio. 2014.

BRASIL. Lei n. 8.666, de 21 de junho de 1993. Regulamenta o art. 37, inciso XXI, da Constituição Federal, institui normas para licitações e contratos da Administração Pública e dá outras providências. Disponível em: <htpp://www.planalto.gov.br> Acesso em: 13 maio. 2014.

BRASIL. Lei n. 9.433, de 8 de janeiro de 1997. Institui a Política Nacional de Recursos Hídricos, cria o Sistema Nacional de Gerenciamento de Recursos Hídricos, regulamenta o inciso XIX do art. 21 da Constituição Federal, e altera o art. $1^{\circ}$ da Lei $\mathrm{n}^{\circ} 8.001$, de 13 de março de 1990, que modificou a Lei $n^{\circ} 7.990$, de 28 de dezembro de 1989. Disponível em: <htpp://www.planalto.gov.br> Acesso em: 13 maio. 2014.

BRASIL. Lei n. 11.959, de 29 de junho de 2009. Dispõe sobre a Política Nacional de Desenvolvimento Sustentável da Aquicultura e da Pesca, regula as atividades pesqueiras, revoga a Lei no 7.679 , de 23 de novembro de 1988 , e dispositivos do Decreto-Lei no 221, de 28 de fevereiro de 1967, e dá outras providências. Disponível em: <htpp://www.planalto.gov.br> Acesso em: 13 maio. 2014.

BRASIL. Resolução n. 357, de 17 de março de 2005. Dispõe sobre a classificação dos corpos de água e diretrizes ambientais para o seu enquadramento, bem como estabelece as condições e padrões de lançamento de efluentes, e dá outras providências. Disponível em: < htpp:// www.mma.gov.br> Acesso em: 13 maio. 2014.

BRASIL. Resolução CONAMA n. 369, de 28 de março de 2006. Dispõe sobre os casos excepcionais, de utilidade pública, interesse social ou baixo impacto ambiental, que possibilitam a intervenção ou supressão de vegetação em Área de Preservação Permanente-APP. Disponível em: < htpp:// www.mma.gov.br> Acesso em: 13 maio. 2014.

BRASIL. Resolução CONAMA n. 237, de 19 de dezembro de 1997. Dispõe sobre a revisão e complementação dos procedimentos e critérios utilizados para o licenciamento ambiental. Disponível em: < htpp:// www.mma.gov.br> Acesso em: 13 maio. 2014.

BRASIL. Sistema de Informações das Autorizações de Uso das Águas de Domínio da União para fins de Aquicultura (SINAU). 2008. Disponível em: <http://www.presidencia.gov.br/sinau>. Acesso em: 10 jan. 2014. 
CONAMA. Conselho Nacional do Meio Ambiente (Brasil) Resoluções do Conama: Resoluções vigentes publicadas entre setembro de 1984 e janeiro de 2012. Ministério do Meio Ambiente. Brasília: MMA, 2012. 1126 p.1. Legislação - Brasil. 2. Política ambiental - Brasil. I. Ministério do Meio Ambiente. II. Título.

DELL'ORTO, M.S.M.; RODRIGUES M.S.M..Cartilha Licença Ambiental de Projetos de Piscicultura em Águas de Domínio da União no Estado da Bahia. $2^{\circ}$ ed. Salvador: SEBRAE Bahia, 2012. 69p.: il. color.

RONDÔNIA. Decreto n. 14.084, de 9 de fevereiro de 2009. Estabelece diretrizes para proteção à pesca e estímulos à aqüicultura do Estado de Rondônia de que trata a Lei n¹.038, de 22 de janeiro de 2002, e dá outras providências. Disponível em: <htpp:// http://www.sedam.ro.gov.br> Acesso em: 13 maio. 2014.

RONDÔNIA. Lei n. 1.038, de 22 de janeiro de 2002. Estabelece diretrizes para proteção à pesca e estímulos à aquicultura do Estado de Rondônia e dá outras providências. Disponível em: < htpp:// www.sedam.ro.gov.br > Acesso em: 13 maio. 2014. 


\section{Toxicidade de amônia em peixes}

Elane Cristina Carvalho Holanda ${ }^{42}$, Ricardo Henrique Bastos de Souza ${ }^{43}$, Erica Bevitorio Passinato ${ }^{44}$, Fernanda Bay-Hurtado ${ }^{45}$, Juliana Ferraz Huback Rodrigues ${ }^{46}$

\section{Introdução}

A manutenção e o conhecimento dos limites de tolerância de uma espécie, em relação à qualidade da água, são requisitos indispensáveis em qualquer sistema de criação (KINNE, 1976). Segundo Ostrensky e Wasielesky (1995), tais fatores influenciam decisivamente no sucesso ou fracasso dessa atividade produtiva.

Inúmeros fatores interferem na qualidade da água, o que exige a realização de estudos detalhados dos processos físicos, químicos e biológicos que ocorrem tanto em sistemas naturais quanto em artificiais, destacando-se a importância dos ciclos biogeoquímicos para o entendimento do ecossistema aquático (CARMOUZE, 1994).

O desenvolvimento e domínio das técnicas de aquicultura têm provocado intensificação nos cultivos de diferentes espécies, existindo uma tendência de incremento na excreção de compostos nitrogenados nesses cultivos (WASIELESKY, 2000).

No ambiente aquático, o nitrogênio pode ser encontrado sob diferentes formas, como: nitrito, nitrato, amônia, óxido nitroso, amoníaco, dentre outras. Amônia e nitrito são tóxicos para peixes, mesmo em baixas concentrações, enquanto nitrato só se torna tóxico em altas concentrações (BALDISSEROTO, 2002), como no caso de sistemas de recirculação de água (sistemas fechados), nos quais altos níveis de nitrato podem ser alcançados como resultado da nitrificação da amônia (ARANA, 1997).

\footnotetext{
42 Engenheira Agrônoma. Especialista em Piscicultura. E-mail: elane@centralnorte.com.br

43 Engenheiro de Pesca. Departamento de Engenharia de Pesca da Universidade Federal de Rondônia.

44 Zootcnista. Mestre em Ciência Animal.

$45 \mathrm{Dr}^{\mathrm{a}}$ em Química. Departamento de Zootecnia da Universidade Federal de Rondônia.

46 Zootecnista. Programa de Pós Graduação em Ciências Ambientais da Universidade Federal de Rondônia.
} 
A quantidade e a natureza de seus compostos muitas vezes determinam a produtividade total do sistema aquático, e, em alguns casos, a disponibilidade desses compostos controla a biomassa algal (SIPAÚBA- TAVARES, 1998).

A toxicidade é uma propriedade relativa de determinada substância química, e se refere ao seu potencial de causar efeito danoso a uma população de seres vivos. Ela é função da concentração da substância química e do tempo de exposição a ela (DAMATO, 2000).

Poucas são as espécies de água doce da região neotropical que têm sua sensibilidade determinada. Essa falta de dados de parâmetros toxicológicos leva à necessidade de serem utilizados dados bibliográficos sobre a toxicidade de determinados efluentes em condições ambientais muito diferentes das encontradas no Brasil (DAMATO et al 1999).

Assim, este trabalho tem como objetivo evidenciar a importância dos estudos toxicológicos da amônia para os peixes, caracterizar a influência da amônia no cultivo de peixes, abrangendo as principais consequências advindas de altas concentrações dos compostos nitrogenados na piscicultura, bem como incentivar o monitoramento e controle das características físico-químicas da água de cultivo animal.

\section{Amônia}

A amônia é um metabólico proveniente da excreção nitrogenada dos peixes e da decomposição microbiana de resíduos orgânicos. O nitrito $\left(\mathrm{NO}_{2}^{-}\right)$é um metabólico intermediário do processo de nitrificação, durante o qual a amônia é oxidada a nitrato $\left(\mathrm{NO}_{3}\right)$, através da ação de bactérias Nitrosomonas e Nitrobacter (KUBITZA, 2003).

A amônia é encontrada no meio aquoso nas formas ionizada $\left(\mathrm{NH}_{4}^{+}\right)$e não ionizada $\left(\mathrm{NH}_{3}\right)$, sendo o principal produto nitrogenado gerado pelo metabolismo de proteínas em peixes teleósteos (FOSTER, GOLDSTEIN, 1969).

A forma não-ionizada $\left(\mathrm{NH}_{3}\right)$ da amônia representa de 75 a 90 \% da excreção nitrogenada dos peixes (DOSDAT et al, 1996), sendo excretada em quase sua totalidade (90\%) através das brânquias por difusão passiva (CAMERON, HEISLER, 1983). É lipossolúvel e se difunde mais facilmente pelas membranas celulares, sendo responsável pelo efeito tóxico da amônia (THURSTON et al, 1981).

Segundo Erickson (1985), embora alguma toxicidade possa ser atribuída à amônia ionizada, a não-ionizada é reconhecidamente a forma química mais tóxica de amônia. Devido sua capacidade de difusão pelas membranas celulares (FROMM, 
GILLETTE, 1968) e, também pelo fato do efeito da amônia ionizada ser considerado menos pronunciado (YU, HIRAYAMA, 1986).

De acordo com Reis e Mendonça (1998), o equilíbrio entre as diferentes formas de amônia depende das características físicas e químicas dos corpos d'água. Elevações do $\mathrm{pH}$ ou da temperatura deslocam o equilíbrio químico no sentido da amônia não-ionizada. Adicionalmente, as forças iônicas são importantes para a definição do equilíbrio entre as espécies de amônia em águas com salinidades elevadas.

Segundo Von Sperling (1995), as principais características dos compostos nitrogenados são: a) é indispensável para o crescimento de vegetais e organismos em geral, pois é utilizado para síntese de aminoácidos; b) os processos bioquímicos de oxidação da amônia ao nitrito e deste para nitrato implicam o consumo de oxigênio dissolvido do meio, o que pode afetar a vida aquática quando a oxigenação do ambiente é menor que o consumo de oxigênio por esses processos; c) a identificação da forma predominante do nitrogênio pode fornecer informações sobre o estágio de poluição. Assim quando a poluição for recente, o perigo para a saúde será maior, pois nesse caso o nitrogênio se apresenta na forma orgânica e amoniacal, forma mais tóxica.

O comportamento tóxico das diferentes parcelas de amônia, particularmente da forma não-ionizada, também depende das condições do meio aquático. Embora as concentrações da forma química $\mathrm{NH}_{3}$ cresçam com aumentos de $\mathrm{pH}$ e temperatura, sua toxicidade diminui (ERICKSON, 1985).

\section{Efeitos tóxicos dos compostos da amônia}

Os primeiros trabalhos que avaliaram a variação da toxicidade dos compostos nitrogenados limitaram-se a indicar a evolução dos efeitos tóxicos da amônia total com o crescimento dos valores do $\mathrm{pH}$ ou da temperatura da água (ERICKSON, 1985).

Como ponto de convergência, todos esses trabalhos indicaram que aumentos nos valores do $\mathrm{pH}$ ou na temperatura da água tornavam a amônia total mais tóxica. No entanto, não foram estabelecidas quaisquer considerações acerca dos efeitos tóxicos das diferentes formas químicas de amônia (REIS, MENDONÇA, 1998).

Os compostos nitrogenados têm sido identificados como o maior produto metabólico em piscicultura (COLT, TCHOBANOGLOUS, 1976), eles ocorrem naturalmente no meio aquoso, entretanto, se as concentrações atingirem níveis 
elevados, podem afetar o crescimento ou provocar mortalidade dos organismos cultivados (THURSTON, 1980).

Diferentes tipos de estudos já foram realizados visando determinar os efeitos tóxicos causados pelos compostos nitrogenados em animais aquáticos, mostrando que as altas concentrações destes compostos diminuem o crescimento, causam danos às brânquias, reduzem o pH sanguíneo, aumentam a demanda de oxigênio, dentre outros prejuízos (COLT, ARMSTRONG, 1981).

$\mathrm{O}$ equilíbrio do balanço entre $\mathrm{NH}_{4}{ }^{+}$e $\mathrm{NH}_{3}$ depende do $\mathrm{pH}$, da temperatura e da composição iônica da água (WAJSBROT, 1991). Uma concentração elevada de amônia na água dificulta a excreção dos peixes, aumentando o nível de amônia no sangue e nos tecidos, causando prejuízos fisiológicos (BOYD e TUCKER, 1998).

Conforme Baldisserotto (2002), além da excreção dos peixes, a concentração da amônia é influenciada pela decomposição do alimento não ingerido e através da introdução de fertilizantes no preparo dos tanques de cultivo.

De acordo com Cavero et al. (2004), a amônia na forma não ionizada $\left(\mathrm{NH}_{3}\right)$ e em concentração elevada pode prejudicar a transformação da energia dos alimentos em ATP, com isso inibindo o crescimento dos peixes e provocando a desaminação dos aminoácidos, o que, por sua vez, impede a formação de proteínas, elemento essencial no crescimento dos animais.

A presença de nitrito no meio aquático, em elevadas concentrações, pode causar problemas hemolinfáticos, uma vez que o mecanismo de toxicidade do nitrito atua sobre o processo de transporte de oxigênio, transformando hemocianina em metahemocianina, a qual é incapaz de transferir oxigênio para os tecidos (GROSS, 2004). Com isto, diminui a quantidade de oxigênio disponível para o metabolismo (TAHON et al 1988) e nestas condições, pode ocorrer hipóxia e mortalidade significativa (CHEN et al 1986).

O nitrato é considerado uma substância com pequeno poder tóxico por parte de pesquisadores, mas por ser o produto final da nitrificação, pode acumular-se em grandes quantidades, principalmente em sistemas fechados de cultivo (THURSTON et al. 1978). Esta substância pode causar efeitos letais ou subletais para diferentes organismos, ou ainda, atuar sinergicamente com outras formas nitrogenadas, tornando-se extremamente importante o estudo dos seus efeitos tóxicos para diferentes espécies (SANTOS, et al 1993).

Os trabalhos de Fromm e Gillette (1968) permitiram observar que o composto $\mathrm{NH}_{3}$ suprime a excreção de amônia endógena através das brânquias dos peixes. 
Dessa forma, a mortalidade poderia ser atribuída às falhas neurológicas e citológicas causadas pelos altos níveis de amônia endógena.

Smart (1976), por sua vez, identificou que os prejuízos causados nas brânquias comprometiam o sistema respiratório dos peixes e que as mortes eram consequência de eventuais asfixias.

Os trabalhos desenvolvidos por Thurston et al. (1981) demostraram que a toxicidade da parcela de amônia não-ionizada diminui com o aumento da temperatura.

Segundo Baldisserotto (2002), a adição de $\mathrm{Ca}^{++}, \mathrm{NaCl}$, e aumento da salinidade podem alterar a toxicidade da amônia, sendo que a concentração letal de $\mathrm{NH}_{3}$ aumenta proporcionalmente como aumento de $\mathrm{Ca}^{++}$.

As pesquisas de Broderius et al. (1985) permitiram identificar uma redução na toxicidade da parcela não-ionizada com incrementos nos valores de $\mathrm{pH}$.

Mesmo com a diminuição da toxicidade da porção não-ionizada da amônia com aumentos nos valores de temperatura ou $\mathrm{pH}$, essa forma química de amônia é substancialmente ainda mais tóxica que a forma ionizada (REIS e MENDONÇA, 1998).

Rubin, Elmaraghy (1977), ao realizarem bioensaios estáticos com salmões, concluíram que para valores de $\mathrm{pH}$ variando entre 7,4 e 7,5 a espécie $\mathrm{NH}_{3}$ é 56 vezes mais tóxica que a $\mathrm{NH}_{4}{ }^{+}$.

Thurston et al. (1981) avaliaram os efeitos tóxicos dos compostos de amônia sobre algumas espécies de peixes e concluíram que alguma toxicidade pode ser atribuída à amônia ionizada. No entanto, para altas concentrações de nitrogênio amoniacal total, quando a toxicidade de $\mathrm{NH}_{4}{ }^{+}$pode ser identificada, a forma química $\mathrm{NH}_{3}$ é de 300 a 400 vezes mais tóxica.

\section{Estudos de ecotoxicidade}

O termo ecotoxicologia foi sugerido pela primeira vez em junho de 1969, durante uma reunião do Committee of the International Council of Scientific Unions (ICSU), em Estocolmo, pelo toxicologista francês René Truhaut (TRUHAUT, 1977). Segundo este autor, a Ecotoxicologia é definida como ciência que estuda os efeitos das substâncias naturais ou sintéticas sobre os organismos vivos, populações e comunidades, animais ou vegetais, terrestres ou aquáticos, que constituem a 
biosfera, incluindo assim a interação das substâncias com o meio nos quais os organismos vivem num contexto integrado (ZAGATTO, BERTOLETTI, 2006).

Ensaios ecotoxicológicos são uma importante ferramenta para avaliação e monitoramento da qualidade de amostras ambientais, efluentes e substâncias puras (ZAGATTO, BERTOLETTI, 2006).

Domingues, Bertoletti (2006) afirmam que o conhecimento da sensibilidade dos organismos, com base em uma diversidade de agentes químicos, é um dos princípios básicos para a escolha de uma espécie a ser utilizada nos ensaios ecotoxicológicos.

Para Magalhães, Ferrão Filho (2008), os estudos ecotoxicológicos são amplamente utilizados visando identificar ambientes aquáticos contaminados e caracterizar os efeitos adversos causados por uma amostra tóxica sobre organismos, porém, muitas vezes não são focados na identificação do composto químico responsável pela toxicidade. Dada a comprovação da toxicidade em amostras ambientais complexas, torna-se de extrema importância a identificação dos compostos ou da classe de compostos responsáveis, assim como a obtenção de evidências sobre as possíveis interações entre substâncias e a biodisponibilidade dos compostos. Com isto, é possível obter subsídios científicos para a tomada de ações de controle e recuperação de ambientes degradados, assim como para o estabelecimento de critérios de qualidade para o sedimento.

Ramade (1977) publicou o primeiro livro de Ecotoxicologia, definindo-a como a ciência que tem por objetivo estudar as modalidades de contaminação do ambiente pelos poluentes naturais ou sintéticos, produzidos por atividades humanas, seus mecanismos de ação e seus efeitos sobre o conjunto de seres vivos que habitam a biosfera.

Deste modo, a Ecotoxicologia nasceu como ferramenta de monitoramento ambiental, baseada principalmente na resposta de organismos individuais a estressores químicos. Portanto, é uma ciência com objetivo próprio de estudo (o fenômeno da intoxicação ambiental em todas as suas nuances e consequências), com finalidade (impedir e prevenir determinada intoxicação ou saber como interrompê-la, revertê-la e remediá-la) e com método (AZEVEDO, CHASIN, 2003).

Na década de 80, as agências ambientais no mundo todo, principalmente nos EUA e na Europa, começaram a desenvolver protocolos padronizados de testes de toxicidade utilizando organismos aquáticos (OECD, 2004).

O chamado "Clean Water Act" foi uma espécie de marco regulatório que deu à Agência de Proteção Ambiental Americana a autoridade para implantar programas de 
controle de poluição, incluindo padrões de efluentes industriais assim como requerimentos para a fixação de padrões de qualidade da água para todos os contaminantes de águas superficiais (MAGALHÃES, FERRÃO FILHO, 2008).

Em 1984, a USEPA estabeleceu o uso de organismos para fins de monitoramento da qualidade da água, o chamado "Monitoramento Biológico" ou, simplesmente, "Biomonitoramento" (USEPA, 1984). Ao mesmo tempo, a Organização para Cooperação Econômica e Desenvolvimento (OECD), na Europa, lançava uma série de protocolos de testes com organismos aquáticos como algas, microcrustáceos e peixes (OECD, 2004).

Os testes ecotoxicológicos, ou bioensaios, para monitoramento e avaliação da qualidade da água têm se tornado bastante comuns nos últimos anos no Brasil. A primeira iniciativa em termos metodológicos se deu em 1975, num programa internacional de padronização de testes de toxicidade aguda com peixes, desenvolvido pelo Comitê Técnico de Qualidade das Águas da International Organization for Standardization (ISO), com participação da Companhia de Tecnologia de Saneamento Ambiental do Estado de São Paulo (CETESB) a convite da Associação Brasileira de Normas Técnicas (ABNT) (ZAGATTO, BERTOLETTI, 2006).

A partir de 1975, foram desenvolvidos e adaptados vários métodos de ensaios de toxicidade aguda e crônica, de curta duração, utilizando alguns grupos e espécies de organismos, dentre os quais se destacam as algas (CETESB, 1994), microcrustáceos (CETESB, 1994) e peixes (ABNT, 2004) de águas continentais e marinhas e, testes com sedimentos (ZAGATTO, BERTOLETTI, 2006).

Embora o conceito de Ecotoxicologia seja amplo, abrangendo a totalidade do ecossistema, muito mais atenção tem sido dada aos efeitos em organismos (i.e. espécies) individuais e poucos são os estudos com enfoque sistêmico. A visão ecossistêmica tem sido enfatizada ultimamente em uma nova abordagem que vem sendo denominada de Ecologia do Estresse (VAN STRAALEN, 2003).

Nesta visão, o conceito de nicho ecológico assume grande importância, à medida que os agentes tóxicos frequentemente interagem com fatores de estresse naturais, como temperatura, $\mathrm{pH}$, pressão osmótica e nutrição, principalmente quando os organismos estão nas bordas de sua amplitude ecológica - que é a faixa de condições ambientais na qual o organismo pode sobreviver e reproduzir - e os efeitos dos agentes toxicológicos tornam-se mais severos (MAGALHÃES, FERRÃO FILHO, 2008).

Uma situação de estresse surge quando algum fator ambiental muda ou quando um organismo encontra-se fora de seu nicho ecológico. Por definição, um 
organismo não pode crescer e reproduzir fora de seu nicho, mas pode sobreviver temporariamente. Portanto, a Ecologia do Estresse traz uma proposta inovadora na Ecotoxicologia, analisando o organismo num contexto mais amplo e mais próximo da realidade do ambiente natural (MAGALHÃES, FERRÃO FILHO, 2008).

Segundo Van Straalen (2003), para que haja um avanço na área de Ecotoxicologia, há que se fazer um esforço para diminuir o "enfoque de testagem" e trazer a Ecotoxicologia mais próxima da Ecologia, o que pode ser evidenciado na figura 1 , ilustrando as faixas de tolerância e os níveis requeridos para manter as atividades biológicas.

Figura 1 - Faixas de tolerância e níveis de atividade biológica requeridos para manter as funções vitais (sobrevivência, crescimento e reprodução) dos organismos sob um gradiente de condições ambientais.

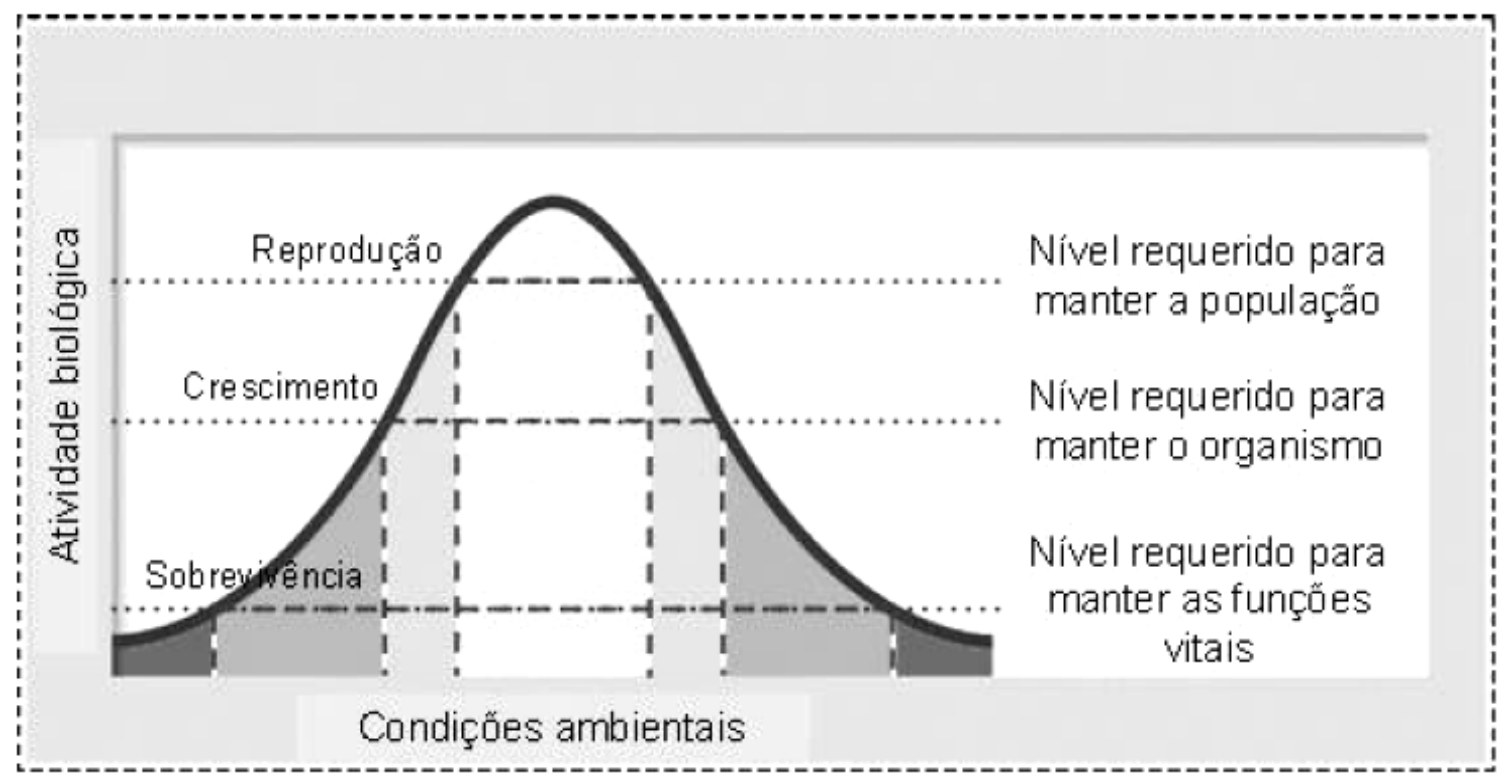

Fonte: Modificado de Ricklefs (2001).

À medida que o organismo é exposto a algum estresse ambiental, seja uma condição extrema ou um agente tóxico, que o leva para fora de sua faixa ótima, algum processo biológico é comprometido (MAGALHÃES, FERRÃO FILHO, 2008).

Além disso, a sensibilidade dos organismos a determinados agentes pode mudar em função das condições ambientais, como por exemplo, a temperatura (LEWIS e HORNING, 1991), o pH (HAVENS, 1992) e o nível alimentar (KOIVISTO et al 1992). 
Deste modo, quanto mais estreita a faixa de tolerância a condições ambientais, maior o nível requerido pelo organismo para sobreviver, crescer e reproduzir-se. Portanto, testes que abranjam estes principais processos biológicos, realizados em condições diferenciadas de exposição, são importantes na determinação dos efeitos de poluentes e contaminantes ambientais (MAGALHÃES, FERRÃO FILHO, 2008).

Os testes de ecotoxicidade permitem avaliar a contaminação ambiental por diversas fontes poluidoras, tais como: efluentes agrícolas, industriais e domésticos, sedimentos, medicamentos e produtos químicos em geral, assim como, avaliar a resultante de seus efeitos sinérgicos e antagônicos (LOMBARDI, 2004).

Tem como vantagem, abranger uma grande variedade de substâncias biologicamente disponíveis em uma amostra ambiental através de um único ensaio, possibilitando a detecção de efeitos de substâncias tóxicas novas que possam surgir no ecossistema aquático (BRANCO, 1989).

Este instrumento torna-se de suma importância na busca de generalizações sobre o grau de toxicidade em vários tipos de corpos hídricos e para determinação da influência direta de elementos vindos das atividades antrópicas e/ou naturais (ZAGATTO, BERTOLETTI, 2006).

Detectam a capacidade inerente de um agente tóxico ou uma mistura em produzir efeitos deletérios nos organismos vivos, permitindo avaliar em que medida as substâncias são nocivas, como e onde se manifestam os efeitos (MAGALHÃES, FERRÃO FILHO, 2008). Os testes de toxicidade com organismos aquáticos realizados em laboratório permitem a avaliação dos efeitos de agentes tóxicos que podem provocar alterações na qualidade da água e prejudicar a biota ali existente. Os organismos representativos do ambiente são utilizados como organismos teste, sendo submetidos a diferentes concentrações do agente tóxico, por um determinado período de tempo (GHERARDI-GOLDSTEIN et al 1990).

De acordo com Soares (1991), os testes de toxicidade servem de base para a política adequada de gestão dos recursos ambientais, constituindo um instrumento fundamental na preservação do ambiente.

\section{Teste de toxicidade aguda}

Os testes de toxicidade aguda avaliam uma resposta severa e rápida dos organismos aquáticos a um estímulo que se manifesta, em geral, num intervalo de 0 a 96 horas (RAND, PETROCELLI, 1985). 
Normalmente o efeito observado é a letalidade ou outra manifestação do organismo que a anteceda, como o estado de imobilidade em invertebrados. Estes testes têm por objetivo determinar a Concentração Letal Média (CL50) ou a Concentração Efetiva Média ( $\left.\mathrm{CE}_{50}\right)$, isto é, a concentração do agente tóxico que causa mortalidade ou imobilidade, respectivamente, a $50 \%$ dos organismos-teste depois de um determinado tempo de exposição (ARAGÃO, ARAÚJO, 2006).

A avaliação aguda de corpos de água, com organismos aquáticos, constitui-se uma abordagem de qualidade de corpos hídricos que recebem despejos domésticos e industriais (BERTOLETTI, ZAGATO, 2006). Tem como objetivo identificar a variabilidade das respostas ao agente entre as diferentes espécies, indicar a toxicidade comparativa e detectar contaminações agudas (MAGALHÃES, FERRÃO FILHO, 2008).

Para Ravera (1998) e Cairns (2002), a associação do monitoramento químico com o monitoramento biológico permite uma melhor avaliação das causas dos efeitos nos organismos, através da identificação de substância que podem estar influenciando na toxicidade das amostras.

No ambiente aquático, entretanto, os poluentes acabam sofrendo uma série de transformações (diluição, fotodegradação, biodegradação, etc.), estando geralmente disponíveis em concentrações crônicas (MAGALHÃES, FERRÃO FILHO, 2008).

\section{Teste de toxicidade crônica}

Os testes de toxicidade crônica dependem diretamente dos resultados dos testes de toxicidade aguda, uma vez que as concentrações subletais são calculadas a partir da CL50 (MAGALHÃES, FERRÃO FILHO, 2008).

Comparado com os testes agudos, estes testes são mais sensíveis à diluição esperada em amostras ambientais. Avalia a ação dos poluentes cujo efeito traduz-se pela resposta a um estímulo que continua por longo tempo, geralmente por um período que vai de $1 / 10$ do ciclo vital até a totalidade da vida do organismo (RAND, PETROCELI, 1985).

De modo geral, porém, não exclusivo, estes efeitos são subletais e observados em situações em que as concentrações do agente tóxico, às quais ficam expostos os organismos, permitem sua sobrevivência, mais afetam uma ou várias de 
suas funções biológicas, interferindo, por exemplo, na reprodução, desenvolvimento de ovos, no crescimento, etc (MAGALHÃES, FERRÃO FILHO, 2008).

Segundo estes mesmos autores, os testes de toxicidade crônica são também utilizados sempre que os testes de toxicidade aguda não forem suficientes para caracterizar um efeito tóxico mensurável, isto é, para detectar indícios de toxicidade aguda.

\section{Toxicidade de amônia em peixes}

Segundo Valenti et al. (2000), a aquicultura brasileira pode ser considerada como importante atividade econômica, gerando ganhos significativos para a economia regional e nacional. De acordo com esse mesmo autor, todas as atividades aquícolas são dependentes dos ecossistemas nos quais está inserida, e estes devem permanecer em equilíbrio para possibilitar a manutenção desta atividade.

Desde a antiguidade, as respostas dos organismos vivos a diferentes tipos de estresse têm sido utilizadas para avaliar a qualidade do meio em que vivem. Há relatos de que Aristóteles (384-322 a.C.), considerado o pai da biologia, submeteu peixes de água doce à água do mar para estudar suas reações (MAGALHÃES, FERRÃO FILHO, 2008).

O primeiro teste de toxicidade com organismos aquáticos que se tem notícia foi realizado em 1816 com insetos aquáticos (BUIKEMA, VOSHELL, 1993).

A toxicidade da amônia para diversas espécies de peixes vem sendo estudada desde 1913 (USEPA, 1984).

Damato, Sobrinho (2001) explicam que o pH é o principal fator que delimita a toxicidade da amônia. Quanto mais elevado for o $\mathrm{pH}$, maior será a proporção da forma não ionizável. A forma ionizável $\mathrm{NH}_{4}{ }^{+}$é encontrada em $\mathrm{pH}$ menores. Portanto a toxicidade da amônia está intimamente associada à forma em que ela é encontrada e esta é pH dependente.

Outro quesito que possui relevante e significativa influência sobre a letalidade é a concentração de oxigênio dissolvido. Segundo Alabaster, Lloyd (1980), o aumento da toxicidade é inversamente proporcional à concentração de oxigênio dissolvido.

$\mathrm{Na}$ criação de organismos aquáticos, os resíduos de nitrogênio são degradantes comuns do meio (TOMASSO, 1994), sendo a excreção dos organismos 
cultivados e a degradação dos restos alimentares, as principais fontes dessas substâncias (GROSS et al. 2000).

A sensibilidade de muitas espécies de teleósteos dulcícolas a altas concentrações de amônia pode culminar na morte dos animais (MORAES et al 2004). Os sintomas de intoxicação aguda pela amônia incluem hiperventilação, hiperexcitabilidade, convulsões, perda de equilíbrio, coma e morte (TWITCHEN, EDDY, 1994).

De acordo com Bellido (2003), a amônia pode ser acumulada nos tecidos dos peixes, podendo causar efeitos secundários como alteração do metabolismo. Seu efeito pode estar relacionado com a perda de equilíbrio, hiper-excitabilidade, aumento da atividade respiratória, aumentos de batimentos cardíacos e bloqueando as funções vitais, danos ao fígado e rins, etc.

Esta toxicidade aguda decorre principalmente de seu efeito no sistema nervoso central, mas o mecanismo de ação da amônia ainda é controverso tanto para mamíferos como para teleósteos (PERSON-LE RUYET et al 1998).

Segundo Randall e Tsui (2002), a causa primária da toxidade da amônia para peixes pode decorrer do efeito despolarizante do íon $\mathrm{NH}_{4}{ }^{+}$nos neurônios, que atua em substituição ao $\mathrm{K}^{+}$, levando a uma ativação excessiva de receptores glutamatérgicos do tipo NMDA (N-Metil-D-Aspartato) e a subseqüente morte da célula.

Segundo Arana (1997) o aumento da concentração de amônia no meio externo, dificulta a excreção da mesma pelos organismos, provocando um aumento no nível de amônia no sangue e nos tecidos que, além de afetar seriamente a fisiologia dos animais (COLT, AMSTRONG, 1981), pode provocar redução ou paralisação da atividade alimentar afim de reduzir a amônia metabólica (GAZZOLA, 2003).

Concentrações subletais de amônia reduzem o crescimento (ROWLAND et al 1995) porque podem causar modificações fisiológicas e histológicas nos rins, baço, tecidos tiróideos e sangue (WOOD, 2001), além de bloquear o processo de fosforilação oxidativa ao nível celular, causando incapacidade de converter a energia alimentar em ATP (RUSSO, THURSTON, 1977).

De acordo com Cicigliano (2009), a criação de peixes, apesar de integralmente dependente da utilização de água sem poluentes, é uma atividade que causa degradação da qualidade da água, sendo classificada pela agência norte-americana de proteção ambiental (EPA), de acordo com Zaniboni-Filho (1997), como fonte potencialmente significativa de poluição das águas. 
A instalação de unidades de piscicultura, embora totalmente dependente da qualidade e quantidade de água disponível, é, por si mesma, uma atividade que causa modificações na qualidade da água. O impacto causado no ambiente varia de acordo com o sistema de cultivo utilizado e, certamente, com as características do corpo d'água que recebe o efluente (ZANIBONI-FILHO, 1997).

$\mathrm{Na}$ piscicultura intensiva, a principal fonte de compostos nitrogenados incorporados à água é a alimentação. No início das criações, quando a biomassa é ainda pequena, observam-se baixos níveis de amônia - compostos resultantes do catabolismo das proteínas, que aumentam proporcionalmente ao aumento da quantidade de alimento fornecido e da biomassa (CAVERO et al 2004). Na criação de peixes carnívoros, essa situação pode ser agravada pelos elevados níveis de proteína das rações (PEREIRA, MERCANTE, 2005).

\section{Legislação brasileira referente a ensaios ecotoxicológicos}

No Brasil a toxicologia aquática é uma área ainda pouco explorada e nossas leis ambientais, com relação a análises ecotoxicológicas na avaliação de poluição, estão em estágio de aperfeiçoamento (CANTARELA, 2009).

Magalhães e Ferrão Filho (2008) citam que a resolução CONAMA n 357/2005 além de estabelecer a classificação dos corpos de água e diretrizes ambientais para o seu enquadramento, também regulamenta as condições e padrões de lançamento de efluentes, proibindo o lançamento em níveis nocivos ou perigosos para os seres humanos e outras formas de vida, ou seja, os efluentes líquidos industriais e domésticos devem atender aos Padrões de Emissão, atendendo aos Padrões de Qualidade, em situações críticas de vazão.

A resolução CONAMA 357/2005 é uma legislação federal e por isso permite a formulação de leis mais restritas de acordo com a necessidade de cada estado brasileiro, ficando livres para estabelecerem seus próprios limites de toxicidade.

\section{Legislação Brasileira referente à amônia}

Entre 1986 e 2005, os padrões brasileiros de qualidade para os corpos d'água e efluentes eram fixados pela Resolução 20 , do Conselho Nacional do Meio 
Ambiente (CONAMA). Nessa Resolução, os padrões para os compostos de amônia eram função exclusiva da classe do corpo d'água (REIS, MENDONÇA, 1998).

Com a edição da Resolução CONAMA 357, em 17 de março de 2005, os padrões para os compostos de amônia em água doce, além de continuarem sendo função da classe do corpo d'água, passaram a depender também do valor do $\mathrm{pH}$ da massa d'água (MAGALHÃES, FERRÃO FILHO, 2008).

Nos corpos d'água salinos, no entanto, a nova Resolução apenas dilatou a concentração limite para uma das classes de corpos d'água, não estabelecendo qualquer relação entre padrão de qualidade e características físicas e químicas da água. Adicionalmente, o novo padrão de qualidade para os efluentes tornou-se menos restritivo (REIS, MENDONÇA, 1998).

\section{Considerações finais}

O constante monitoramento das características químicas é essencial para identificação, quantificação e dimensionamento da amônia e demais compostos químicos específicos no ambiente.

Ensaios toxicológicos específicos de amônia são importantes instrumentos para assegurar a qualidade do meio ambiente, e produção piscícola, visto que detectam impactos acidentais ou advindos da implantação do cultivo de peixes.

\section{Referências}

ALABASTER, J.S.; LLOYD, R. Water quality criteria for freshwater fish. London, Butterworks, 297p. 1980.

ARAGÃO, M.A.; ARAÚJO, R.P.A. Métodos de ensaios de toxicidade com organismos aquáticos. Pp 117-147. In: P.A. Zagatto, E. Bertoletti (eds.), Ecotoxicologia Aquática Princípios e Aplicações. Editora Rima. São Paulo, São Carlos. 478p. 2006.

ARANA, L.V. Princípios Químicos de Qualidade da Água em Aqüicultura: Uma Revisão para Peixes e Camarões. Editora da Universidade Federal de Santa Maria, Santa Maria, RS. 1997. 
AZEVEDO, F.A.; CHASIN, A.A.M As bases toxicológicas da Ecotoxicologia. Editora Rima, São Paulo, São Carlos, 340p. 2003.

BALDISSEROTO, B. Fisiologia de Peixes Aplicada à Piscicultura. Editora da Universidade Federal de Santa Maria, Santa Maria, RS. 2002.

BELLIDO, N., Tratamento de Efluentes Contendo Amónia, Dissertação de Mestrado, Departamento de Ciência dos Materiais e Metalurgia, PUC-Rio, Brasil. 2003.

BERTOLETTI, E.; ZAGATTO, P.A. Aplicação dos Ensaios Ecotoxicológicos e Legislação Pertinente. In: ZAGATTO, P.A.; BERTOLETTI, E. Ecotoxicologia Aquática - Princípios e Aplicações. 1 ed. São Paulo, SP, Brasil. Editora Rima, p. 347-382. 2006.

BRANCO, S. M. Considerações sobre a Nova Legislação Brasileira de Qualidade de Águas. Revista DAE, 49 (157):185-187. 1989.

BOYD C.E., TUCKER C.S. Pond Aquaculture Water Quality Management. Kluwer Academic Publishers, Norwell, 700p. 1998.

BRASIL. Ministério do Meio Ambiente. Resolução CONAMA n. 357 de 17/03/2005. Dispõe sobre a classificação dos corpos de água e diretrizes ambientais para seu enquadramento.

BRODERIUS, S. Toxicity of ammonia to early life stages of the smallmouth bass at four pH values. Environmental Toxicology and Chemistry, n. 4, p. 87-96, 1985.

BUIKEMA,A.L.;VOSHELL,J.R. Toxicity studies using freshwater benthic macroinvertebrates. Chapman and Hall, NY. 488p. 1993.

CAIRNS, J. JR. Environmental monitoring for the preservation of global biodiversity: THe role in sustainable use of the plant. International Journal of Sustainable Development and World Ecology, v.9,n.2, p.135-150. 2002.

CAMERON, J. N.; HEISLER, N. Studies of ammonia in rainbow trout: physicochemical parameters, acid-base behaviour and respiratory clearance. Journal of Experimental Biology v.105, p.107-125. 1983.

CANTARELA, B.A. Avaliação Ecotoxicológica do Petróleo Cru, utilizando metamysidopsis munda (Crustacea: Mysidacea). 37 f. Monografia (Oceanografia) Centro de Ciências Humanas e Naturas, Universidade Federal do Espírito Santo, Vitória, 2009.

CARMOUZE, J.P. O metabolismo dos ecossistemas aquáticos. 1. ed. São Paulo: Edgard Blücher / Fapesp. 253p. 1994. 
CAVERO, B.A.S.; PEREIRA-FILHO, M.; BORDINHON, A.M.; et al. Tolerância de juvenis de pirarucu ao aumento da concentração de amônia em ambiente confinado. Pesquisa Agropecuaria. brasileira, v.39, n.5. p. 513-516. 2004.

CETESB. Água - Teste de toxicidade aguda com Daphnia similis. Norma CETESB L5.018. 25p., 1994.

CICIGLIANO, G. D. Avaliação da Qualidade da Água em Piscicultura com Sistema de Cultivo em Tanques-Rede no Município de Santa Fé do Sul - SP. 81 f. Dissertação (Mestrado Engenharia Civil) - Faculdade de Engenharia, Universidade Estadual Paulista, Ilha Solteira, 2009.

DAMATO, M; SOBRINHO, P. A. Determinação da toxicidade aguda de cloreto de amônio para una espécie indicadora regional: hyppessobrycom callistus. In: Associação Brasileira de Engenharia Sanitária e Ambiental; AIDIS. Saneamento ambiental: desafio para o século 21. Rio de Janeiro, ABES, p.1-4, 2001.

DAMATO, M. Workshop sobre Qualidade da Água na Aqüicultura. Anais...Pirassunga: CEPTA, 92 p. 2000.

DAMATO, M.; MORITA, M D ; ALEM SOBRINHO, P. Emprego de uma Especie de Rotifero, Brachionus Calyciflorus, na determinação da toxicidade aguda no Afluente e Efluente de sistemas de Lodo ativados em duas refinarias de petróleo. XX Congresso Brasileiro de Engenharia Sanitária e Ambiental, Rio de Janeiro, Anais... v. 1, n. 1, 1999.

DOMINGUES, D.F.; BERTOLETTI, E. Seleção, manutenção e cultivo de organismos aquáticos. In: Zagatto, P.A. Bertoletti, E. (eds), Ecotoxicologia aquática: Princípios e aplicações. São Carlos. RIMA. p.153-184. 2006.

DOSDAT, A., SERVAIS, F., MÉTAILlER, R., HUELVAN, C., DESBRUYERES, E. (1996). Comparasion of nitrogenous losses in five teleost fish species. Aquaculture v.141,p.107-127. 1996.

ERICKSON, R.J. An evaluation of mathematical models for the effects of ph and temperature on ammonia toxicity to aquatic organisms. Water Research, n. 19, p. 1047-1058, 1985.

FOSTER R.P., GOLDSTEIN L. Formation of excretory products. In: W.S. Hoar e D.J. Randall (Eds.), Fish Physiology, 1. Academic Press, New York, NY: p. 313-350. 1969.

FROMM, PO; JR GILLETE. Effect of ambient ammonia on blood ammonia and nitrogen excretion of rainbow trout (Salmo gairdneri). Comp. Bioch. And physiology, v.26, p.887-896. 1968. 
GAZZOLA, A.C. Efeito da amônia e do oxigênio dissolvido na sobrevivência de alevinos de dourado, Salminus brasiliensis. Dissertação de Mestrado, Universidade Federal de Santa Catarina, Florianópolis. 47p. 2003.

GROSS, A. Acute and chronic effects of nitrite on white shrimp, Litopenaeus vannamei, cultured in low-salinity brackish water. Journ. Aquacult. Society, v.35, n.3, p.315-321. 2004.

GROSS, A, CE BOYD; CW WOOD. Nitrogen budget and transformations in channel cat fish ponds. Aquaculture Engineering, v.24, p.113-132. 2000.

GHERARDI,G.; BERTOLETTI,E. Procedimento para utilização de testes de toxicidade no controle de efluentes líquidos. São Paulo: CETESB/PROCOP,17p. 1990.

GROSS, A. Acute and chronic effects of nitrite on white shrimp, Litopenaeus vannamei, cultured in low-salinity brackish water. Journal of the aquaculture society, v.35, n.3, p.315-321. 2004.

HAVENS, K. E. Acid and aluminum effects on sodium homeostasis and survival of acid-sensitive and acid-tolerant cladocera. Canadian Journal of Fisheries and Aquatic Science., 49: 2393-2398. 1992.

KINNE, O. Mar. Ecol. Ed. John Wiley \& Sons, NY, USA, Vol III, part 1, 577.1976.

KOIVISTO, S.; KETOLA, M. \& WALLS, M. Comparison of five cladoceran species in short- and long-term copper exposure. Hydrobiologia, 248: 125-136. 1992.

KUBITZA, F. Qualidade da água no cultivo de peixes e camarões. 1 ed. Jundiaí, 229 p. 2003.

LEWIS, P.A.; HORNING II, W.B. Differences in acute toxicity test results of three reference toxicants on Daphnia at two temperatures. Environmental Toxicology and. Chemistry,10: 1351-1358. 1991.

LOMBARDI, J.V. Fundamentos de toxicologia aquática. In: M.J.T. Ranzani-Paiva, R.M. Takemota \& M.A.P. Lizama (eds.), Sanidade de organismos aquáticos. Org. Livraria Varela, São Paulo. 426p 2004.

MAGALHÃES, D. P.; FERRÃO FILHO, A. S. A Ecotoxicologia como ferramenta no biomonitoramento de ecossistemas aquáticos. Oecologia Brasiliensis. v. 12, n. 3, p. 355-381. 2008. 
MORAES, G.; V.L. POLEZ; G.K. IWAMA. Biochemical responses of two Erythrynidae fish to environmental ammonia. Brazilian Journal of Biology. v.64, n.1. p. 95-102. 2004.

OECD (Organization for Economic Cooperation and Development). OECD Guidelines for Testing Chemicals - Daphnia sp., Acute Immobilization Test. Guideline 202. 12p. 2004.

OSTRENSKY, A; WASIELESKY, W.J. Acute toxicity of ammonia of various life stages of the São Paulo shrimp Penaeus paulensis Pérez-Farfante, 1967. Aquaculture v.132, p.339-347. 1995.

PEREIRA, L.P.F.; MERCANTE, C.T.J. A Amônia nos sistemas de criação de peixes e seus efeitos sobre a qualidade da água. Uma revisão. Boletim do Instituto de Pesca, v.31, p. 81-88. 2005.

PERSON-LE RUYET, J.; G. BOEUF., J. ZAMBONINO. Infante, physiological changes in turbot and seabream juveniles exposed to exogenous ammonia. Comparative. 1998.

RAMADE, F. Ėcotoxicologie. Masson, Paris, France. 205 p. 1977.

RAND, G.M.; PETROCELLI, S.R. Fundamentals of aquatic toxicology. Washington. 665p. 1985.

RAVERA, O. Utility and limits of biological and chemical monitoring of the Aquatic environment. Annali di Chimica, v.88, p.11-12. 1998.

REIS, J.A.T.; MENDONÇA, A.S.F. Análise dos padrões para os compostos amoniacais segundo a Resolução CONAMA 20/86. Revista de Engenharia Sanitária e Ambiental, v. 3, n. 4, p. 146-154, 1998.

RICKLEFS, R. E. A Economia da Natureza. Guanabara-Koogan, 5a. Edição, 503 p. 2001.

ROWLAND, S.J.; ALLAN, G.L.; HOLLIS, M.; PONTIFEX, T. Production of the Australian freshwater silver perch, Bidyanus bidyanus (Mitchell), at two densities in eathen ponds. Aquaculture, 130,p.317-328. 1995.

RUBIN, A.J.; ELMARAGHY, G.A. Studies on the toxicity of ammonia, nitrate and their mixtures to guppy fry. Water Research, n. 11, p. 927-935, 1977.

RUSSO, R.; THURSTON, R. The acute toxicity of nitrite to fishes. In: R. TUBB (editor) Recent Advances in Fish Toxicology. U.S. Environmental Protection Agency, EPA- 
600/3 - 77 - 085. U.S. Goverment Printing Office, Washington, D.C., p.118-131. 1977.

SANTOS, MHS, KF MIRANDA, LH POERSCH \& WJ WASIELESKY. Efeito agudo do nitrato sobre alevinos da tainha Mugilplatanus (Pisces: Mugilidae). Simpósio Brasileiro sobre Cultivo de Camarões. Anais... 811-821. 1993.

SIPAÚBA-TAVARES, L.H. Limnologia aplicada à aqüicultura. Boletim Técnico FUNEP, São Paulo, 1: 1-72.

SIPAÚBA-TAVARES, L.H. Limnologia dos sistemas de cultivo. In: Carcinicultura de água doce.São Paulo: FUNEP. p.47-75. 1998.

SIPAÚBA-TAVARES, L.H. Influência da luz, manejo e tempo de resistência sobre algumas variáveis limnológicas em um viveiro de piscicultura. Biotemas, Florianópolis, v. 8, n. 1, p. 61-71, 1995.

SMART, G. The effect of ammonia exposure on gill structure of the rainbow trout (salmo gairdneri). Journal of Fish Biology, n. 8, p. 471-475, 1976.

SOARES, A.M.V.M. Ecotoxicologia e determinação de riscos ecológicos. Prática e Perpectivas. In: CONFERÊNCIA NACIONAL SOBRE A QUALIDADE DO AMBIENTE. Lisboa, Anais...1: 43-52. 1991.

TAHON, JP, D van HOOF, C VINCKIER, R WITTERS, M de LEY \& R LONHE. The reaction of nitrite with the haemocyanin of Astacus leptodactylus. Biochemistry Journal v.249. p.233-242. 1988.

THURSTON, R.V., PHILIPPIS, G.R., RUSSO, R.C. Increased toxicity of ammonia to rainbow trout (S. gairdneri) resulting from reduced concent rations of dissolved oxygen. Canadian Journal of Fisheries and Aquatic Sciences v.38, p.983-988. 1981.

THURSTON, R.V.; RUSSO R.C.; SMITH C.E. Acute toxicity of ammonia and nitrite to cutthroat trout fry. Trans. Am. fish. Soc.,107: 361 368. 1978.

THURSTON, RV. Some factor affecting the toxicity of ammonia to fishes. EPA Ecol. Res. Ser., EPA-600/9-80-034: 118-137. 1980.

TOMASSO, JR. Toxicicity of nitrogenous Wastes to Aquaculture Animals. Reviews Fish. Sci., v.2, n.4, p. 291-314. 1994.

TRUHAUT, R. Ecotoxicology: objectives, priciples and perspectives. Ecotoxicology and Environmental Safety, I, p.151-173. 1977. 
USEPA - Environmental Protection Agency. Technical Support Document for Water Quality-Based Toxic Control. EPA - Washington D.C. 135 p. 1984.

VALENTI, W.C.; POLI, C.R.; PEREIRA, J.A.; BORGHETTI, J.R. Aqüicultura no Brasil. Bases para um desenvolvimento sustentável. CNPQ / Ministério da Ciência e Tecnologia, Brasília. 399 p. 2000.

VAN STRAALEN, N.M. Ecotoxicology bacomes stress ecology. Environmental Science and Tecnology, v.37, n.17. p.324A-33A. 2003.

VON SPERLING, M.V. Princípio do tratamento biológico de águas residuárias. IN: Introdução a qualidade das águas e ao tratamento de esgotos. 1995.

WAJSBROT, N.; GASITH, A.; KROM, M.D.; POPPER, D.M. Acute toxicity of ammonia to juvenile gilthead seabream Sparatus aurata under reduced oxygen. Aquaculture, 92, 1991.

WASIELESKY, W.J. Culture of pink shrimp Farfantepenaues paulensis in Patos Lagoon estuary: effects of environmental parameters and management. Biological Oceanography Ph.D, thesis, Fundação Universidade Federal do Rio Grande, RS, Brazil. 2000.

WOOD, C.M. Toxic responses of the gill. In: Schlenk, D. Benson, W.H. Target organ toxicity in marine and freshwater teleosts, 1. Organs Taylor \& Francis, London, p.189. 2001.

ZAGATTO, P.A., BERTOLETTI, E. Ecotoxicologia Aquática: Princípios e Aplicações. RIMA Editora, São Carlos. 478p. 2006. 


\section{Boas práticas de manejo para sanidade em pisciculturas}

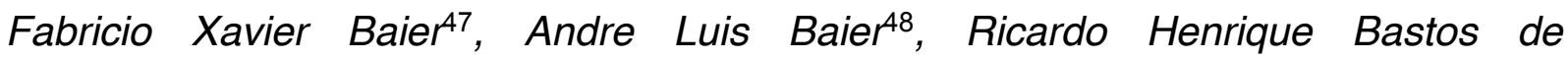
Souza $^{49}$,Jucilene Cavali50, Marlos Oliveira Porto ${ }^{51}$, Juliana Ferraz Huback Rodrigues $^{52}$

\section{Introdução}

A piscicultura assume importância cada vez maior na produção de alimentos para o mundo, com uma taxa de crescimento de $10 \%$ ao ano. A produção de peixes vem sendo desenvolvida em diversos países como a China, Índia, Equador, Chile dentre outros. No Brasil é ainda uma atividade recente, porém apresenta grande potencialidade para produção devida suas condições geográficas, de clima favorável e grande potencial hídrico como: rios, lagoas, reservatórios e açudes (FIPERJ, 2014).

O pescado é uma das principais fontes de proteínas na alimentação humana, mas não é apenas um bom alimento, pois também proporciona óleos, rações e produtos de valor para indústria. Esse uso tão variado pode ser explicado pelas diversas espécies de peixes que existem e pelas variadas estruturas histológicas e composição química de suas partes.

Conforme dados estatísticos do Ministério da Pesca e Aquicultura (MPA, 2011) a produção de pescado nacional de 2011 foi de $1.431 .974,4$ toneladas, minutando um acréscimo de aproximadamente $13,2 \%$ em relação a 2010 . A pesca extrativa marinha permaneceu como a principal fonte de produção de pescado, responsável por $553.670,0$ toneladas $(38,7 \%)$ do total de pescado, seguida pela aquicultura continental que produziu $544.490,0$ toneladas $(38,0 \%)$, pesca extrativa continental responsável por $249.600,2$ toneladas $(17,4 \%)$ e aquicultura marinha

\footnotetext{
47 Médico Veterinário. Especialista em Piscicultura. E-mail: fabriciobaier@gmail.com

48 Técnico em Piscicultura. Especialista em Piscicultura.

49 Engenheiro de Pesca. Mestre em Ciência Animal. Departamento de Engenharia de Pesca da Universidade Federal de Rondônia.

50 Dra em Zootecnia. Departamento de Zootecnia da Universidade Federal de Rondônia.

51 Dr em Zootecnia. Departamento de Zootecnia da Universidade Federal de Rondônia.

52 Zootecnista. Pós-doutoranda no Programa de Ciências Ambientais EMBRAPA/UNIR.
} 
$84.214,3$ toneladas (6 \%). No ano de 2011 a produção aquícola nacional teve uma ampliação de 31,1 \% comparando com a produção de 2010. A produção aquícola nacional de origem continental aumentou de forma significativa de 2010 para 2011, com um incremento de aproximadamente $38 \%$ demonstrando um crescimento consistente desse setor da aquicultura.

Em países nos quais, a atividade de cultivo de peixes é considerada bem desenvolvida, como os Estados Unidos e Japão, a perda anual da produção associada aos problemas de doenças é estimada em 7,5 \% e $8 \%$, respectivamente. Esses valores não são maiores graças à existência de sistemas integrados de diagnose, fiscalização e controle de doenças em piscicultura.

No Brasil, essas taxas de perda devem ser pelo menos duas vezes maiores, uma vez que inexiste qualquer órgão ou sistema governamental ou dos criadores que desempenhe funções de controle e prevenção. $O$ problema tem aumentado intensamente nos últimos anos, em todo o país, em especial nos estados que apresentam maior produção. Doenças, portanto, deve ser consideradas um obstáculo para que o Brasil atinja níveis adequados de produtividade e produção.

Para se manter vivo e saudável, um organismo deve manter suas funções vitais em equilíbrio. Essa propriedade dos seres vivos é conhecida como homeostase. A quebra desse equilíbrio interno causa enfermidades e pode ter inúmeros fatores causadores.

Em qualquer cultura pecuária, o controle de doenças assume importância fundamental quando se busca atingir altos níveis de produtividade. O conhecimento sobre doenças de animais domésticos, sua prevenção e controle, é relativamente grande quando comparado com o que se conhece em relação a peixes cultivados pois a maioria dos peixes cultivados atualmente está apenas no início de seu processo de domesticação. Existem, todavia, formas de diagnosticar, prevenir e controlar doenças em ambientes de cultivo que independem de um conhecimento aprofundado sobre os fatores causadores de enfermidades.

A piscicultura é uma alternativa agropecuária com excelente perspectiva de desenvolvimento e retorno econômico otimizando os recursos da propriedade, sendo importante destacar, que a pesca extrativa está estagnada com tendências de declínio o que influi diretamente nos custos de captura.

Mediante atuais modificações na cadeia produtiva da aquicultura, intensificação na produção, consumidores do mercado nacional e internacional que prezam pela inocuidade e segurança alimentar, somados aos incentivos para acréscimo de produção na atividade aquícola, este trabalho tem por objetivo ressaltar a necessidade irrestrita de melhorias e aperfeiçoamentos no manejo coligindo a 
necessidade de criar, implantar e viabilizar Boas Práticas de Manejo (BPMs) para produzir alimento com qualidade e quantidade, segurança alimentar, progresso nos índices zootécnicos e econômicos quanto à segurança ambiental dando sustentabilidade a cadeia produtiva (LIMA, 2014).

\section{Enfermidades: visão geral}

Apesar de ser comum considerar que os danos causados por enfermidades estão limitados àqueles associados à mortandade, as perdas devido simples presença de agentes patogênicos podem ser bem maiores. Enfermidades crônicas podem induzir alterações comportamentais, fisiológicas e estruturais em peixes que resultam em perdas econômicas. Matéria e energia ofertadas através da alimentação que poderiam ser utilizadas pelo peixe, para crescimento ou reprodução, são sequestradas pelos agentes patogênicos, diretamente, através da sua alimentação ou, indiretamente, pelas respostas dos peixes à sua presença.

Os peixes apresentam uma série de barreiras contra a entrada e o estabelecimento de agentes patogênicos e o desenvolvimento de doenças. A primeira linha de defesa é representada pelo muco e a epiderme com escamas. $O$ muco contém enzimas e anticorpos que podem matar organismos invasores. Pele e escamas representam barreiras físicas ao ataque de parasitas.

No entanto, a simples presença de um agente patogênico em potencial nos peixes cultivados ou nos viveiros não determina, obrigatoriamente, o aparecimento de doenças. No meio ambiente, peixes são intensamente "atacados" por formas infestantes de agentes patogênicos sem, necessariamente, ficar doentes. Outros são portadores de microrganismos virulentos sem que apresentem os sintomas das doenças que esses microrganismos causam (hospedeiros portadores assintomáticos). Como dito anteriormente, muitos dos agentes causadores de doenças em piscicultura (como bactérias e fungos) são organismos comuns do sistema aquático e, em situações normais, não causam qualquer enfermidade.

Agentes patogênicos conseguem invadir o corpo de um peixe e iniciar uma doença quando as defesas desse peixe estiverem reduzidas. Organismos verdadeiramente patogênicos só necessitam de uma pequena baixa na resistência do peixe para se reproduzir e causar a enfermidade. Em geral, os fatores mais importantes na redução da capacidade de defesa de um peixe são os danos mecânicos, que quebram a primeira barreira protetora representada pelo sistema 
muco-pele-escama e o estresse que causa uma redução significativa na resposta imunológica do peixe. Esses dois fatores, geralmente, ocorrem simultaneamente.

Enquanto que no meio ambiente os peixes podem efetivamente nadar em busca de condições ambientais mais favoráveis, em cultivo, esses organismos estão confinados a um espaço limitado e em densidades bem superiores àquelas encontradas no meio ambiente. Mecanismos de transmissão de espécies com ciclo vital direto são bastante favorecidos nessas condições, estando os peixes cultivados, mais sujeitos ao desenvolvimento de epidemias causadas por esses parasitas.

Além disso, a maior densidade, a maior manipulação e a limitação de movimentos, também aumentam as possibilidades de aparecimento de danos físicos e de estresse, mesmo em ambientes de cultivo corretamente manejados. Peixes, em geral, assim como outros animais, são capazes de suportar o estresse, por certo período de tempo, parecendo saudáveis. Todavia, a continuidade dos fatores estressantes provoca a redução da eficiência dos mecanismos de resistência, abrindo caminho para a Invasão, estabelecimento e crescimento de populações de agentes patogênicos e, assim, iniciando uma epidemia.

Dentre os fatores que promovem a redução da resistência dos peixes em piscicultura estão:

- Aumento na densidade de peixes cultivados, associado à má qualidade da água. Dentre os fatores que tendem a variar com o aumento de densidade estão à redução na concentração de oxigênio dissolvido, temperatura e pH indesejáveis, aumento nos níveis de gás carbônico, de amônia de nitrito, de matéria orgânica, dentre outros.

- Manuseio inadequado, captura, uso de redes inadequadas, transporte e seleção.

- Nutrição inadequada, desconhecimento das necessidades nutricionais de peixes em sistema Semi - intensivo, é uma fonte importante de desequilíbrio fisiológico e estresse de peixes cultivados.

- Baixa condição sanitária, não utilização de técnicas adequadas para prevenção da entrada e disseminação de agentes patogênicos no cultivo. 


\section{Boas práticas de manejo na piscicultura}

Boas práticas de manejo na piscicultura podem ser caracterizadas como o conjunto de práticas necessárias para a produção de pescado de qualidade, de acordo com as leis e regulamentos da indústria de alimentos e que levam em consideração a segurança do alimento, a saúde animal e a sustentabilidade ambiental e socioeconômica.

O incentivo governamental favoreceu que a piscicultura se desenvolvesse nos últimos anos, refletindo assim em maior produção e produtividade, lucro e sustentabilidade por parte dos piscicultores e aprimoramento com utilização de sistemas de criação que possibilita maiores densidade de estocagem.

O objetivo da atividade é gerar renda, alcançando alta produtividade com baixo custo, consequentemente aumentar o lucro, oferecer à população alimento de qualidade, boa digestibilidade, rico em proteína, vitaminas, minerais, baixo valor calórico e excelente fonte de ômega 3 e 6 , conjunto de fatores que demonstra a necessidade do empreendedor ter conhecimentos adequados sobre a espécie cultivada, suporte técnico, ser organizado, administrar o empreendimento e desenvolver medidas estratégicas para atividade (OLIVEIRA, 2009).

O planejamento do empreendimento por meio de boas práticas ambientais é de fundamental importância, considerando-se as condições de manejo dos ecossistemas aquáticos que serão utilizados (OLIVEIRA, 2009). Na piscicultura, a profilaxia é uma prática que não pode ser desconsiderada quando se pretende evitar as doenças que podem manifestar-se em peixes cultivados (PAVANELLI et al 2008). Há a necessidade de adoção de um manejo sanitário preventivo, de boas práticas para reduzir o impacto das principais enfermidades nos cultivos e garantir a segurança dos produtos colocados à mesa do consumidor (KUBITZA, 2011).

O controle sanitário deve partir de cuidados básicos no manejo. O piscicultor deve prevenir o aparecimento de doenças visando diminuir ou atenuar problemas de saúde nos peixes (LOPES, 2012).

Os diversos setores envolvidos na atividade de aquicultura veem ponderando suas ações com a associação do uso de Boas Práticas de Manejo (BPMs), utilizando como instrumentos: manejo eficaz, melhoramento de tecnologias, manejo ecológico nas pisciculturas com o intuito de praticar uma aquicultura sustentável e competitiva, reduzindo práticas prejudiciais ao meio ambiente, através do profissionalismo dos produtores. A adoção de BPMs promove a manutenção de ambiente ótimo para 
criação dos peixes o que aumenta a possibilidade de proporcionar bem-estar aos peixes (FERREIRA, BARCELL, 2008).

Frequentemente, ocorrem empreendimentos na piscicultura em que o produtor é inexperiente, o suporte técnico muitas vezes não é capacitado, profissionais sem a devida experiência e conhecimento, não investem em equipamentos adequados para realizar as atividades rotineiras, estando preocupados, somente, em retorno rápido do capital investido no empreendimento, logo, não seguem as medidas de boas práticas de manejo e/ou manejo sanitário preventivo e dos embasamentos técnicos da atividade. Esta situação tem por consequência grandes perdas e prejuízos, não sendo o bastante, propicia expressivamente o alojamento e propagação de agentes patogênicos perigosos nas áreas de cultivo e para o ecossistema envolvido (KUBITZA, 2008).

Produzir peixe em cativeiros favorece a exposição dos animais a condições adversas relacionadas ao ambiente, visto que podem ocorrer muitos erros de manejo, alimentação de forma errônea, baixa qualidade da água, compra de alevinos sem procedência, infectados ou doentes. Os animais nestas condições apresentam variáveis graus de estresse e baixa imunidade, fatores importantes que predispõe a susceptibilidade para o desencadeamento de doença. Independente do tipo de sistema de cultivo, o piscicultor pode deparar-se com doenças, sejam elas advindas do manejo inadequado, em que grande maioria delas se enquadra, ou de fatores externos ao cultivo (DIAS et al 2013).

Existe ainda muita dificuldade em realizar o tratamento de doenças que surgem na piscicultura, devido à falta de técnicos capacitados, falta de conhecimentos e acompanhamento técnico adequado em todo o processo. Para minimizar os problemas e aquilatar as condições na criação é necessário aderir a um manejo higiênico sanitário com medidas sanitárias, limpeza, desinfecção, controle de trânsito de pessoas, animais e veículos, descartes e efluentes, controle de segurança e qualidade da água e realizar quarentena. Medidas estas que tem como objetivo o controle sanitário e a saúde dos animais.

\section{Medidas de boas práticas de manejo}

A localização dos empreendimentos deve ser em áreas onde a probabilidade de poluição e contaminação da água e do pescado por agentes físicos, químicos ou biológicos seja mínima. Ainda assim o empreendimento deverá estabelecer procedimentos para garantia da qualidade da água de cultivo do pescado e para 
riscos específicos devem ser concebidos planos de contingência para lidar com emergências.

Em instalações terrestres, onde haja a captação e lançamento de água para o ambiente, a estrutura deve permitir que os tanques ou viveiros tenham entrada e saída de água separadas.

Quanto aos critérios para a seleção de áreas para a construção, os empreendimentos aquícolas não devem ter restrições ambientais nos quesitos relacionados às áreas ecologicamente sensíveis, solo e água.

O empreendimento deverá apresentar declaração do órgão ambiental, ou documento equivalente, baseado em dados técnicos de que as espécies cultivadas estão adaptadas na bacia hidrográfica receptora da operação. Relativamente aos sistemas de abastecimento e drenagem em cultivos terrestres, quando aplicável, o empreendimento aquícola deve levar em consideração os seguintes critérios:

- Captação de água de locais não poluídos e sem restrições ambientais, de acordo com a outorga de direito de uso da água;

- Construir canais que não desperdicem água e com configuração que evite processos erosivos;

- Dimensionar o sistema de drenagem de forma a possibilitar o rápido esvaziamento do viveiro, impedir a passagem do pescado e ser de fácil manuseio;

- Utilizar filtros de malha, de dimensão autorizada pelo órgão de defesa sanitária, tanto no afluente quanto no efluente;

- O sistema de drenagem deve retirar a água do fundo, mas permitir a drenagem da água de superfície quando necessário;

- Verificar a possibilidade de estabelecer o reuso da água, adotando sistema fechado ou semifechado, quando couber.

Quanto aos critérios de distanciamento mínimos entre tanques-rede de uma mesma linha e entre linhas, levar em consideração a qualidade de água do local, correntes, densidade de estocagem e volumes dos tanques redes. Os empreendimentos devem manter distanciamento mínimo entre os cultivos de forma a evitar problemas sanitários e danos ao ambiente.

As atividades de aquicultura devem ser conduzidas de uma maneira que assegure a saúde e o bem-estar dos animais aquáticos cultivados e a manutenção de um ambiente de cultura saudável em todas as fases do ciclo de produção. De forma a respeitar as autorizações de uso de água e licenciamento ambiental o empreendedor deve adquirir a quantidade de formas jovens estipuladas de acordo 
com o sistema de cultivo e disponibilidade de área. Viveiros de reprodutores devem estar fisicamente separados dos viveiros de larva, alevinos e viveiros de engorda.

Durante a etapa de seleção de fornecedores de formas jovens, o empreendedor em aquicultura, sempre que possível, deve realizar visitas ao fornecedor, ver suas instalações, verificar o manejo sanitário e acompanhar a embalagem e expedição destes.

O transporte deve ser realizado nas horas menos quentes do dia para evitar estresse e consequente mortalidade. Para a aclimatação dos alevinos no momento da soltura recomenda-se os seguintes procedimentos:

As embalagens deverão ser colocadas flutuando, ainda lacradas, por cerca de 15 a 20 minutos na água do local da estocagem, até que se atinja o equilíbrio térmico entre as temperaturas interna e externa das água. Com as embalagens abertas deve-se adicionar lentamente alguns litros de água às embalagens e liberar os alevinos cuidadosamente.

O empreendedor deve observar no momento da recepção das formas jovens os seguintes quesitos:

As evidências de depuração, por meio da observação da presença de fezes. A depuração deve ser feita pelo fornecedor de formas jovens e monitorada pelo empreendedor;

Apresentação do atestado sanitário e guia de trânsito animal emitido pelo órgão competente ou profissional credenciado, seguindo as especificações do Manual de Preenchimento para Emissão de Guia de Trânsito Animal de Animais (GTA) e Invertebrados Aquáticos vigente;

Recomenda-se a apresentação de laudo técnico emitido pelo fornecedor de formas jovens contendo as seguintes informações: declaração que informe a idade, o tamanho e quantidade dos alevinos, teste de desempenho, comprovação de licenciamento ambiental do laboratório, quando couber; A temperatura da água deve ser definida em função do tempo de transporte e das especificidades climáticas das diferentes regiões, visando ao conforto térmico dos animais; Os produtos utilizados no transporte de alevinos devem ser registrados no Ministério da Agricultura, Pecuária e Abastecimento (MAPA).

Aclimatar as formas jovens, antes da soltura, por no mínimo 15 a 30 minutos analisando os seguintes parâmetros; Cada novo lote de animais aquáticos introduzidos em um empreendimento deve ser colocado em unidades prédesinfetadas; Adquirir a quantidade estipulada de acordo com o sistema de cultivo e disponibilidade de área, conforme estipulado na outorga; Verificar aspecto, comportamento e uniformidade de lote na chegada das formas jovens. 
Banhos visando à redução e/ou eliminação de possíveis agentes causadores de enfermidades de peixes a serem introduzidos no cultivo são bastante desejáveis. Muito frequentemente, transportadores de peixes vivos adicionam sal de cozinha (cloreto de sódio) na água das caixas de transporte, com o objetivo de minimizar o estresse. Este transporte, portanto, dependendo da concentração de sal usada e o tempo de transporte pode ser considerado como banho profilático. Sal é relativamente eficiente contra diversos ectoparasitos, helmintos, protozoários e mesmo bactérias.

\section{Manipulação dos peixes}

Isolamento dos peixes: Deve-se evitar misturar lotes diferentes de peixes, seja pela transferência de alguns indivíduos de um viveiro para outro já estocado, seja juntando todos em um único viveiro.

Mistura de peixes de tamanhos diferentes: $O$ sistema imunológico de peixes grandes é mais bem desenvolvido do que o de peixes mais novos. Assim, peixes maiores, mais velhos, podem ser portadores assintomáticos de parasitos e microrganismos, representando uma fonte de enfermidades para os peixes menores.

“Restos" de safra no reservatório de água: É muito comum a prática de "dispensa" os peixes remanescentes de safras anteriores nos reservatórios responsáveis pelo acúmulo da água utilizada na piscicultura. Esta é uma pratica absolutamente/desnecessária e extremamente perigosa, pois estes peixes podem vir a se tomar foco de enfermidades. O ideal é que tal reservatório seja livre de peixe.

\section{Manejo diário}

Desinfecção de equipamentos: Redes, puçás ou qualquer outro equipamento utilizado em um viveiro, devem ser completamente secos ou desinfetados antes de serem utilizados em outro viveiro. Desse modo, formas infestantes/infectantes de parasitos e microrganismos patogênicos não são disseminadas no cultivo.

A desinfecção das redes é mais problemática, pois o uso contínuo de desinfetantes ou, como recomendado por diversos autores, secagem sob o sol, pode reduzir significativamente o tempo de vida útil dessas redes. Outra opção, apesar de 
evidentemente mais onerosa e dificilmente implementada na prática, é destinar redes, puçás e equipamentos em geral para uso exclusivo em um único viveiro. Em médio prazo, contudo, o custo é bem menor (menor uso das redes $=$ menor desgaste) e o manejo é bem mais seguro, tratando-se de enfermidades. $\mathrm{Na}$ impossibilidade de executar as sugestões acima, é recomendável lavar as redes com jatos de água logo após o seu uso em um viveiro. Restos de lama, peixes mortos e outros organismos, que podem conter formas infectantes de agentes patogênicos, serão removidos, diminuindo, um pouco, a probabilidade de disseminação de algumas enfermidades.

Visitas indesejadas: Diversos visitantes de um viveiro de piscicultura, principalmente, as aves, são utilizados durante o ciclo vital de alguns parasitos ou como vetores de doenças de origem microbianas.

Limpeza e desinfecção de viveiros e tanques: As técnicas de calagem e desinfecção são importantes na eliminação de formas de resistência de microrganismos patogênicos e parasitos do sistema, antes do início de uma nova safra (ou atividade de produção). Essa desinfecção irá garantir, também, a eliminação de organismos invertebrados que habitam o fundo (por exemplo. anelídeos e moluscos bivalves). Tais invertebrados podem ser vetores ou hospedeiros de diversos organismos prejudiciais à prática da piscicultura.

Uso de viveiro de fertilização: Em algumas pisciculturas, um pequeno viveiro é utilizado para efetuar superfertilização da água com restos de ração e esterco animal. Esta água, rica em fitoplâncton, é transportada com a ajuda de carropipa para "fertilizar" outros viveiros. Todavia, apesar desses viveiros não serem estocados com peixes do cultivo, pequenos peixes, como lambaris e barrigudinhos, podem estar presentes e ser portadores de agentes causadores de enfermidades. A água, evidentemente, pode também estar contaminada com formas infectantes/infestantes de parasitos e microrganismos virulentos.

Remoção de peixes mortos: Como muitos dos agentes patogênicos de peixes cultivados são, na realidade, saprófitos, deixar peixes mortos em um viveiro é fornecer alimento para que as populações desses agentes aumentem. Quanto maior a população de agentes patogênicos, maior a possibilidade de estes infectarem outros peixes, causando doença. Peixes mortos não-removidos (ou qualquer excesso de matéria orgânica em decomposição) comprometem, ainda, a qualidade de água, podendo ser um fator causador de estresse.

Adicionalmente, se o peixe tiver morrido por doença causada por algum agente patogênico (por exemplo. vermes ectoparasitos), removendo-o do sistema, os agentes patogênicos também serão removidos. 
Peixes mortos retirados do viveiro devem ser dispensados em uma vala contendo cal virgem, distante de qualquer corpo de água da piscicultura.

Remoção de macrófitas: Macrófitas podem servir, também, de substrato para posturas de ovos de algumas espécies de parasitos de peixes (ex. Argulus. sp) ou como ambiente para o desenvolvimento de outros organismos que fazem parte do ciclo vital de agentes causadores de enfermidades (por exemplo: sanguessugas, anelídeos e moluscos). Sua retirada é essencial no controle desses parasitos.

\section{Água de cultivo}

O empreendimento aquícola deve estabelecer medidas para controle e monitoramento da qualidade da água, que incluam no mínimo:

Quando necessário, o tratamento dos afluentes, advindos da água captada para o abastecimento de tanques escavados deve ser feito utilizando-se uma ou mais, dos possíveis métodos: decantação, desinfecção, oxigenação, retenção de sólidos em suspensão e filtragem física e/ou biológica; Análises biológicas, microbiológicas e físico-químicas, em acordo com a legislação vigente, para a verificação da qualidade da água;

Definição de uma rotina de análise diária dos parâmetros de qualidade da água no empreendimento, tais como transparência, nível de oxigênio, temperatura, pH e amônia; delegando um ou mais trabalhadores treinados para esta função. Os parâmetros de qualidade da água adotados devem ser adequados à espécie cultivada e à densidade de estocagem. Para isto, recomenda-se que o empreendedor adote práticas baseadas em informações técnicas e científicas para o cultivo específico.

O empreendimento deve realizar as análises recomendadas acima pelo menos duas vezes ao dia (pela manhã e ao final do dia), devendo os registros das análises estar disponíveis para consulta pelos órgãos fiscalizadores;

Para a manutenção da qualidade da água e bons níveis de oxigênio dissolvido nos casos em que se fizer necessário, deve-se priorizar o uso de aeradores, bem como de outros equipamentos destinados a esta finalidade, para a melhoria da oxigenação da água. 


\section{Avaliação da qualidade da água de cultivo}

A água possui caráter primordial para a atividade, sendo necessário que apresente condições adequadas e favoráveis, ser abundante e de fundamental importância que tenha boa qualidade. Os peixes dependem da água para realizar todas as suas funções vitais, ou seja: respirar, alimentar, reproduzir, excretar. Por isso, manterá qualidade da água utilizada nos cultivos é de fundamental importância para se produzir peixes com qualidade.

Já há aparelhos ou kits de análises disponíveis no mercado nacional para medir os principais parâmetros de qualidade de água. Quase sempre esse material é caro e o piscicultor precisa avaliar bem o que e onde comprar, por outro lado, possuir alguns desses materiais pode significar a salvação de um determinado cultivo.

A quantidade de água necessária para realizar-se um manejo adequado dos cultivos é relativa, depende muito de parâmetros como: do tipo de solo (se é permeável ou não), da perda por evaporação, da espécie que será cultivada (cultivos de trutas exigem muito mais água do que o de tilápias ou carpas). No entanto, de um modo geral, o piscicultor deve ter água suficiente para encher ou renovar todo o viveiro em, no máximo, 15-20 dias. Isso corresponde a uma taxa de renovação de mais ou menos de cinco a sete por cento por dia. O critério para determinação do quanto será renovado deve ser um só: bom senso. Se a água que estiver nos viveiros apresenta uma boa qualidade e não havendo indícios de problemas nos cultivos, não há por que jogar fora essa água.

O cálculo cinco a sete por cento/dia, baseia-se no fato de que em algum momento pode haver problemas com a água (falta de oxigênio, excesso de temperatura, elevadas concentrações de amônia ou de nitrito, excesso de fitoplâncton, etc.). Nessas ocasiões, a renovação de água não só é importante como também fundamental e quanto mais água for possível captar, mais fácil será realizar o manejo dos viveiros.

É preciso pensar também, que se a quantidade de água disponível for muito pequena, o tempo necessário para encher os viveiros no início dos cultivos será muito maior, podendo até mesmo atrasar o povoamento.

Para a piscicultura os viveiros são ecossistemas que possuem grande variedade biótica e interações diversificadas. Em condições impróprias, a água, procede em avaria ao crescimento, reprodução, produção e manejo, saúde, alimentação, sobrevivência e qualidade dos peixes, aumento de custo de produção, logo é responsável por insucesso na atividade (MORAES, 2012). 
O primeiro passo é cuidar de fato da qualidade da água na criação (KUBITZA, 2012). Em geral, os produtores falam que a qualidade da água é muito importante, mas poucos realmente a monitoram de forma profissional. A grande maioria nem monitora. A análise de parâmetros físicos (Temperatura, turbidez e transparência) e químicos ( $\mathrm{pH}$, alcalinidade, dureza, oxigênio dissolvido e amônia,) da água constitui importante ferramenta para monitorar a qualidade hídrica do sistema de produção (MATSUZAKI et al 2004).

\section{Densidade}

O estabelecimento de uma densidade máxima relacionada ao tamanho dos peixes, fase de desenvolvimento e sistema de produção. A densidade máxima tem que, no mínimo, estar de acordo com as exigências legais, caso existam;

A comprovação de que a densidade máxima estabelecida deve estar baseada em documentação científica ou orientação técnica que considera a saúde e o bem-estar dos peixes, quando não houver legislação disponível e a disponibilidade de registros de estocagem de cada ciclo de produção.

\section{Alimentação}

Ao selecionar o alimento a ser utilizado, o empreendimento em aquicultura deve analisar se este possui registro junto ao órgão competente, verificar se o seu desempenho foi comprovado por meio de testes e pesquisas. O empreendimento ainda deve observar os seguintes quesitos, quando da seleção do alimento: Devem ser fabricados e obtidos de fontes reconhecidas e o uso de alimentação que contenha ingredientes geneticamente modificados só deve ser permitido, com a etiqueta do produto que especifica a sua inclusão. De forma a possibilitar ao empreendedor a verificação da qualidade da ração fornecida, evitando prejuízos econômicos e ambientais, recomenda-se que o empreendimento aquícola:

Solicite declaração ao fornecedor de alimentação animal, contendo os seguintes parâmetros: ingredientes; uniformidade; flutuabilidade; tempo de resistência; percentual de finos; testes de qualidade da ração (microbiológicos, bromatológicos, vitamina $\mathrm{C}$, digestibilidade, aflatoxinas). Realize as análises para avaliação da qualidade da alimentação, no recebimento e registre as informações relacionadas. A administração do alimento deve ser realizada de acordo com a fase 
de crescimento em que se encontram os animais. Uso de rações nutricionalmente completas. Cada fase de crescimento deve apresentar seu procedimento de alimentação e os registros de todas as administrações de alimentos feitas.

Observar a data de validade dos alimentos, bem como sua identificação correta, antes de ser administrada. O tratador deve ficar atento ao consumo dos peixes e ajustar a quantidade, frequência e horário do fornecimento da alimentação, com base na resposta alimentar dos animais. Para isto, monitorar frequentemente os níveis de oxigênio e a temperatura da água, além de observar a presença de sobras e velocidade de consumo.

O empreendedor deve demonstrar, por meio dos registros apropriados, que os parâmetros de temperatura da água, disponibilidade de alimento natural e nível de oxigênio e biomassa a ser trabalhada são analisados previamente para o cálculo da quantidade de ração a ser administrada. Distribuir os alimentos nos viveiros, de forma uniforme, com um alimentador mecânico ou manualmente a lanço, da forma mais homogênea possível.

O empreendimento aquícola deve garantir que os rótulos, notas fiscais e declarações especificando os componentes da alimentação estão disponíveis no local e são mantidos por dois anos ou um ano a mais do que o ciclo de produção da espécie cultivada. Todos os aditivos utilizados na alimentação devem ter autorização do órgão competente e os seguintes registros relacionados ao seu uso têm que estar disponíveis no local:

- Os utilizados em alimentação comum (ex. vitaminas, minerais e pigmentos);

- Os utilizados em alimentos especiais (imunoestimulantes, probióticos);

- Antibióticos.

- O empreendimento deverá utilizar alimentos e ingredientes que não contenham níveis perigosos de contaminantes químicos, biológicos e físicos e ou outras substâncias adulteradas. Não alimentar com animais vivos sem certificação de origem, pois o risco sanitário pode ser alto.

\section{Sanidade e biossegurança}

O empreendimento aquícola deve garantir o correto uso de medicamentos e tratamentos zoossanitários, incluindo no mínimo, os seguintes critérios:

- Todo e qualquer tratamento dos animais deve ser realizado sob responsabilidade de profissional habilitado de acordo com a doença a ser tratada, os registros deverão estar disponíveis;

- Manter o uso mínimo e responsável de produtos químicos, medicamentos zoossanitários e antibacterianos permitidos para uso em aquicultura, 
procurando sempre manter a linha de controle das causas e profilaxia de doenças;

- Só é permitido o uso de medicamentos permitidos para o uso em aquicultura.

\section{Monitoramento da saúde dos animais}

O empreendimento aquícola deve adotar medidas eficazes para o monitoramento da saúde dos animais, contemplando no mínimo:

- Garantia de que as formas jovens dos animais introduzidos no empreendimento apresentem GTA emitido pela autoridade competente, segundo normas vigentes;

- Durante o recebimento das formas jovens devem ser verificados os sinais de vacinação, realizando amostragem por lote de animais;

- Realização de pesquisa e registro de surtos ou episódios de doenças ocorridos no empreendimento, que devem estar disponíveis e serem comunicados aos demais empreendimentos aquícolas localizados no entorno;

- Notificação às autoridades competentes o conhecimento de quaisquer doenças de notificação obrigatória (listadas pela OIE) em seu empreendimento ou nas proximidades das fazendas;

- Quando da utilização de vacinas, assim como de medicamentos e quaisquer outras substâncias autorizadas na criação de tilápias, estas deverão ser armazenadas, acondicionadas e aplicadas de acordo com as recomendações do fabricante, respeitando-se o período de carência (ou intervalo de segurança).

- Utilização de técnicas presuntivas que auxiliem na avaliação do estado de saúde do animal, tais como, observação geral dos sinais clínicos, análises internas realizadas por técnicos qualificados;

- Em casos de alta incidência da enfermidade ou altas mortalidades, providenciar a coleta e o envio de amostras, pelo órgão de defesa sanitária animal, para análise laboratorial de enfermidades na Rede Nacional de Laboratórios do Ministério da Pesca e Aquicultura;

- Tratamento dos animais doentes com medicamentos recomendados para a doença específica, respeitando-se o tempo correto de tratamento, a dose e período de carência recomendados pelo laboratório fabricante;

- Manter os animais doentes sob observação e quando necessário deve-se proceder à matança de emergência, seguindo as recomendações órgão de defesa sanitária animal; 
- Nos casos em que se decide recolher ou sacrificar uma população devido à presença de uma doença, o procedimento deve ser feito sem causar dor ou sofrimento aos animais.

\section{Conclusão}

Devido à intensificação no sistema de produção inevitavelmente é necessário inserir as medidas de Boas Praticas no manejo para produzir com quantidade, principalmente qualidade e desenvolvimento sustentável da atividade e dos setores vinculados à cadeia de produção.

Com o manejo adequado das condições ambientais, nutricionais e do próprio peixe, os animais cultivados estarão sob condições mínimas de estresse e consequentemente, serão capazes de responder de forma adequada às "tentativas" de invasão de agentes patogênicos e ao estabelecimento de enfermidades. Seguindo as boas práticas de manejo o piscicultor estará com certa segurança garantindo uma boa manutenção da saúde dos peixes de seu plantel.

As boas práticas de manejo preventivas proporcionam redução no impacto ambiental no sistema de produção, obtêm bons resultados na produção de peixe, pois restringe o estresse aos peixes, mantendo a saúde dos organismos aquáticos, bem como melhora o índice zootécnico e minimizando causas e incidência de doenças.

O suporte técnico aos piscicultores deve ser capacitado com devida experiência e conhecimento, requer equipamentos apropriados para realização das atividades rotineiras, seguimento das medidas de boas práticas de manejo e/ou manejo sanitário preventivo e dos fundamentos técnicos da atividade.

\section{Referências}

AMERICO, J.H., CICIGLIANO, G. D., CARVALHO, S. L. (2012). Avaliação de alguns parâmetros físico-químicos da água de uma piscicultura com sistema de cultivo em tanques-rede. Fórum Ambiental da Alta Paulista. Anais... 8, 60 - 71 p. Brasil. 
DIAS, M.T., ARAUJO, C.S., PORTO, S.M., VIANA, G.M., MONTEIRO, P.C. Sanidade do Tambaqui, Colossoma macropomum, nas fases de larvicultura e alevinagem, $1^{a}$ ed, 42p. Amapá, Macapá, Brasil. 2013

DIAS, M.T. Manejo e sanidade de peixes em cultivo. $1^{\text {a}} e d$. Macapá, Pará, Brasil: EMBRAPA. 2009.

FERRAZ, D.R., AMARAL, A.A. Variação nictemeral dos parâmetros Físico-Químicos da água de um viveiro de cultivo de Tilápia. Encontro Latino Americano de Pós Graduação, 5. Anais... 2010.

FERREIRA, D., BARCELL, L.J. Enfoque Combinado empreendedorismo como Boas Praticas de Manejo e como Medidas mitigadoras de estresse na piscicultura. Revista Científica da Pesca, Aquicultura e Limnologia ,v.34, n.4, p.601-611. 2009.

FERREIRA, P.E.. Efeito da temperatura sobre a taxa metabólica da carpa-comum (Cyprinus Carpio Linnaeus, 1758). Revista Brasileira Engenharia de Pesca. v.4, p.110.2009.

FIPERJ.S.D. Aquicultura. Disponível em http://www.fiperj.rj.gov.br/index.php/ aquicultura/piscicultura. Acesso em 25 de Março de 2014.

IMBIRIBA, E. P., JUNIOR, J. CARVALHO, L. O. (2000). Rcomendações Tecnicas Ministério da Agricultura e Abastecimento. Parametros Ambientais e Qualidade da Água na Piscicultura , EMBRAPA. Belém, Pará, Brasil.

KUBITZA, F.. Açude de Orós Tilapicultura consolida desenvolvimento econômico e social, mas piscicultores ainda lutam por licenciamento. Panorama da Aquicultura , $v$. 21 n.127. 2011.

KUBITZA, F. Piscicultura: Boas Práticas no Manejo Sanitário. Panorama da Aquicultura, v.19 n.112.2009.

KUBITZA, F. Qualidade da água na produção de peixes - Parte II. Panorama da Aquicultura v.8, n.46. 1998.

KUBITZA, F. Qualidade da Água no cultivo de peixes e camarões. Jundiaí, SP, Brasil. 2003.

KUBITZA, F. Tambaqui alimentando com eficiência para reduzir custos. Panorama da Aquicultura , v.22. 2012.

KUBITZA, F. Tilápias na mira dos patógenos: Sanidade Aquicola. Panorama da Aquicultura, v.18.n.107. 2008. 
LIMA, M. Levantamento dos pontos críticos e aplicação de boas práticas de manejo na base de piscicultura Carlos Eduardo Matiaze. Trabalho de Conclusão de Curso (Graduação em Engenharia de Pesca e Aquicultura) - Universidade Federal de Rondônia. 76p. 2014.

LIMA, W., GARCIA, C. Qualidade da água em Ribeirópolis-SE. Scientia Plena ,v. 4, n.12. 2008.

LOPES, J. C. Técnico em Agropecuária: Piscicultura/ EDUFPI. Brasil. 2012.

MACEDO, J. A. Águas e Águas $3^{a}$ ed.. (J. A. Macêdo, Ed.) Belorizonte, MG, Brasil. 2007.

MATSUZAKI, M., MUCCI, J. L., ROCHA, A. A. Comunidade fitoplanctônica de um pesqueiro na cidade de São Paulo. Revista de Saúde Pública. v.38. p 679-686. 2004.

MERCANTE, C., MARTINS, Y. CARMO, C., OSTI, J., PINTO, C., TUCCI, A. Qualidade de água em viveiro de Tilápia do Nilo (Oreochromis niloticus): caracterização diurna de variáveis físicas, químicas e biológicas, São Paulo, Brasil. Bioikos, v.21, n.2, p. 79-88. 2007.

MILLAN, R. N. Dinâmica da Qualidade da água em tanques de peixes de sistema Pesque-Pague:.Aspectos Físicos-Químicos e plâncton. Jaboticabal, SP, Brasil. 2009.

MORAES, J. D. Piscicultura Para Principiante Em Mato Grosso. CUIABA, MT, Brasil: INTERGRAF. 2012.

MPA. (2011). Boletim Estatísticoda Pesca e Aquicultura. 60p. Brasil.

OLIVEIRA, R. C. O panorama da aquicultura no Brasil: A prática com foco na sustentabilidade. Revista Intertox de Toxicologia, Risco Ambiental e Sociedade ,v. 2. 2009.

OLIVEIRA, R. D. Efeitos da temperatura nas respostas cardio-respiratórias e na respiração aérea acessória de jejum, Hoplerythrinus unitaeniatus (Erythrinidae) aclimatação a 15, 20, 25 e $30^{\circ} \mathrm{C}$ e submetidos a variações de 02 ambiental. São Carlos, SP, Brasil. 2003.

OSTRENSKY , A., BOEGER, W. Piscicultura, Fundamentos e Técnicas de Manejo. In: A. OSTRENSKY, W. BOEGER, Piscicultura, Fundamentos e Técnicas de Manejo (p. 211 p). Guaíba, RS, Brasil: Livraria e Editora Agropecuária. 1998.

PAVANELLI, G., TAKEMOTO, R. Doenças de peixes: profilaxia, diagnóstico e tratamento. $3^{a}$ ed., 311p. Maringá, PR, Brasil: EDUEM. 2008. 
PEREIRA, L. P., MERCANTE, C. T. A amônia nos sistemas de criaçao de peixes e seus efeitos sobre a qualidade da água - uma revisão. Boletim do Instituto de Pesca, v.31. n.1, p.81-88. 2005.

SEBRAE. Projeto Estruturante do Pirarucu da Amazônia. Manual de Boas Práticas de Produção e Cultivo do Pirarucu em Cativeiro, 42p. Porto Velho, Rondônia, Brasil. 2010. 

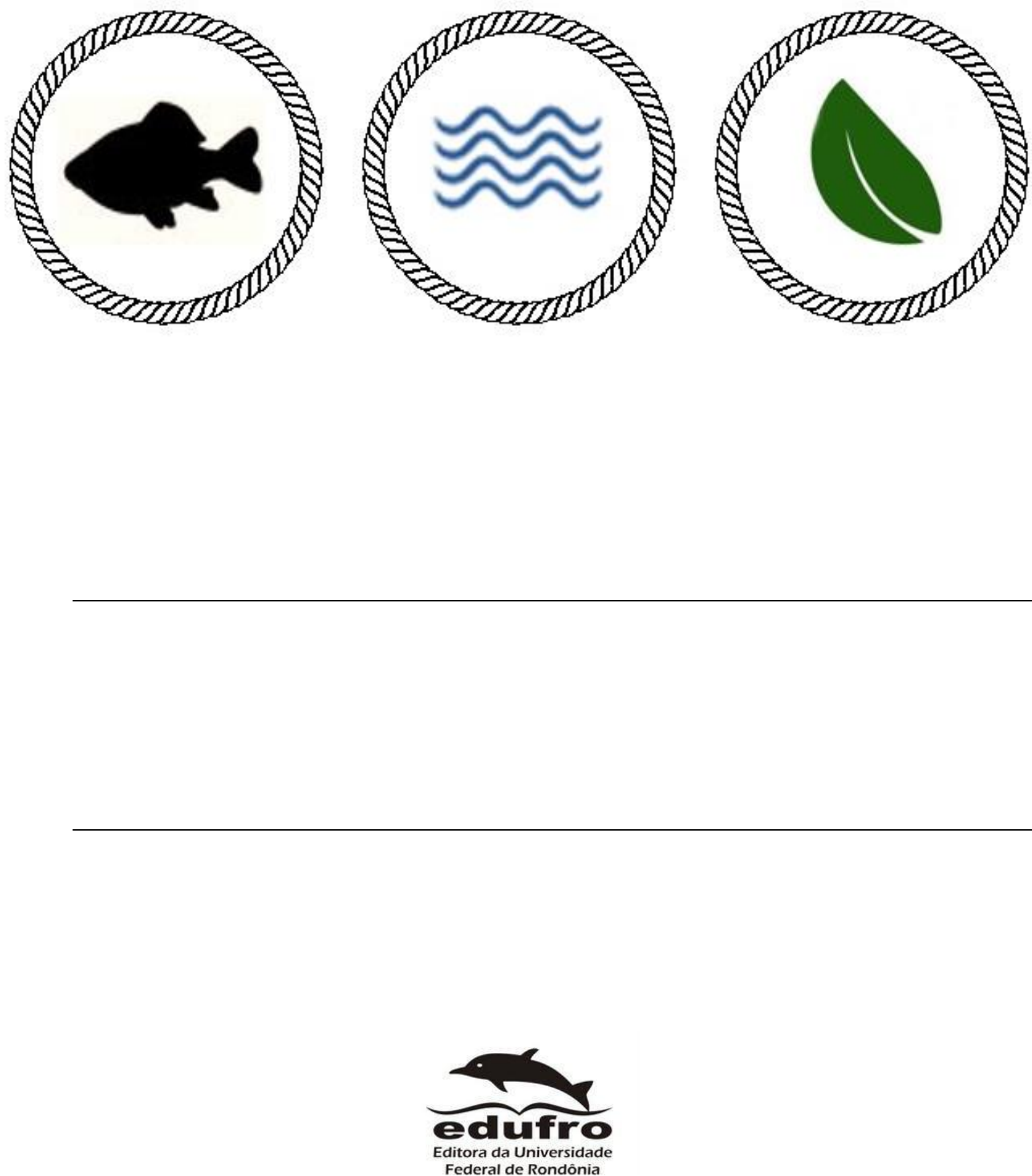

Av. Presidente Dutra, 2965 - Centro

Porto Velho - RO - CEP: 76801-974

Fone: (69) 2182-2175

www.edufro.unir.br

edufro@unir.b 